.

1)
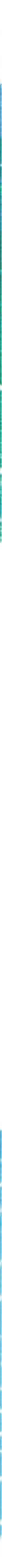

RACISMO

RELIGIOSO EM

ESCOLAS DA BAHIA:

AUTOAFIRMAÇÃO E INCLUSÃO DE

CRIANÇAS E JOVENS DE TERREIRO

ADEMAR CIRNE
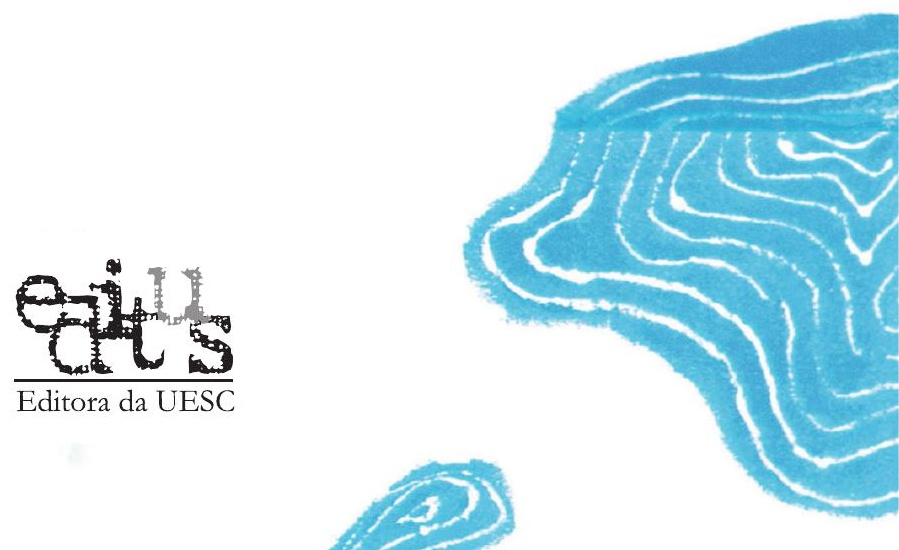

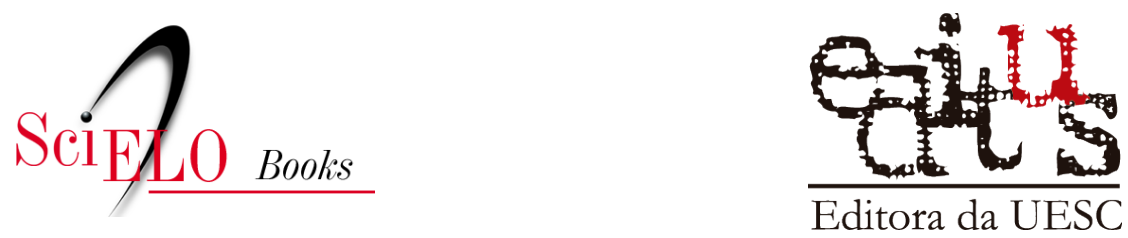

\title{
Racismo religioso em escolas da Bahia autoafirmação e inclusão de crianças e jovens de terreiro
}

\author{
Ademar Cirne
}

\section{SciELO Books / SciELO Livros / SciELO Libros}

CIRNE, A. Racismo religioso em escolas da Bahia: autoafirmação e inclusão de crianças e jovens de terreiro [online]. Ilhéus, BA: Editus, 2020, 203 p. Transfluência series. ISBN: 978-65-8621316-4. https://doi.org/10.7476/9786586213294.

\section{(c) (1)}

All the contents of this work, except where otherwise noted, is licensed under a Creative Commons Attribution 4.0 International license.

Todo o conteúdo deste trabalho, exceto quando houver ressalva, é publicado sob a licença Creative Commons Atribição 4.0.

Todo el contenido de esta obra, excepto donde se indique lo contrario, está bajo licencia de la licencia Creative Commons Reconocimento 4.0. 


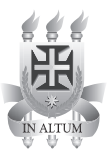

\section{Universidade Estadual de Santa Cruz}

DIRETORA DA EDITUS

Rita Virginia Alves Santos Argollo

\section{Conselho Editorial:}

Rita Virginia Alves Santos Argollo - Presidente Alexandra Marselha Siqueira Pitolli Andréa de Azevedo Morégula Carlos Pereira Neto

Dejeane de Oliveira Silva Iracildo Silva Santos

Helga Dulce Bispo Passos Luciana Sedano de Souza Lurdes Bertol Rocha Maria Cristina Rangel Maria Luiza Silva Santos Maurício Santana Moreau Raquel da Silva Ortega Sabrina Nascimento

GOVERNO DO ESTADO DA BAHIA

Rui Costa - Governador

\section{SECRETARIA DE EDUCAÇÃO}

Jerônimo Rodrigues - Secretário

UNIVERSIDADE ESTADUAL DE SANTA CRUZ Alessandro Fernandes de Santana - Reitor Maurício Santana Moreau - Vice-Reitor

\section{Universidade Federal do Sul da Bahia - UFSB}

Reitora Joana Angélica Guimarães da Luz Vice-Reitor Francisco José Gomes Mesquita Pró-Reitor de Pesquisa e Pós-Graduação Rogério Hermida Quintella Diretor de Pós-Graduação Nadson Ressye Simões da Silva

Programa de Pós-Graduação em Ensino e Relações Étnico-Raciais - PPGER

Coordenação Geral PPGER Cynthia de Cássia Santos Barra Coordenação PPGER, campus Sosígenes Costa Eliana Póvoas Pereira Estrela Brito Coordenação PPGER, campus Paulo Freire Gilson Brandão de Oliveira Júnior

Projeto Transfluência: Ensino, Gênero, Relações Étnico-Raciais

Coordenação Editorial

Cynthia de Cássia Santos Barra Laura Castro de Araújo

\section{Comissão de Seleção de Obras - PPGER/UFSB} Apoena Dandara Silva Santos Cynthia de Cássia Santos Barra Francisco A. Nascimento Junior Francisco Antônio Nunes Neto Hamilton Richard A. F. Santos Laura Castro de Araújo Paulo César Pereira de Jesus Rebeca Valadão Bussinger Yuri Miguel Macedo 


\section{RACISMO \\ RELIGIOSO EM \\ ESCOLAS DA BAHIA:}

AUTOAFIRMAÇÃO E INCLUSÃO DE CRIANÇAS E JOVENS DE TERREIRO

ADEMAR CIRNE

Ilhéus - Bahia 2020
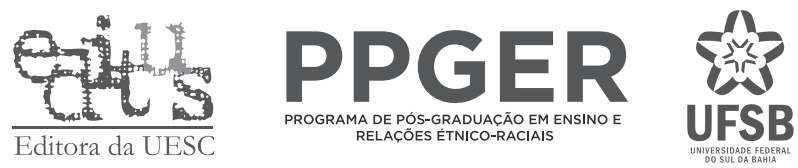


\section{Copyright (C)2020 by ADEMAR CIRNE}

Direitos desta edição reservados à EDITUS - EDITORA DA UESC PPGER/UFSB

A reprodução não autorizada desta publicação, por qualquer meio, seja total ou parcial, constitui violação da Lei n ${ }^{0}$ 9.610/98.

Depósito legal na Biblioteca Nacional,

conforme Lei ${ }^{\circ}$ 10.994, de 14 de dezembro de 2004.

\section{GERÊNCIA DE PRODUÇÃO}

Sabrina Nascimento

\section{PROJETO GRÁFICO}

Lia Cunha

Tiago Ribeiro

FINALIZAÇÃO

Deise Francis Krause

REVISÃO

Pedro de Carvalho Neto

Tess Chamusca Pirajá

Dados Internacionais de Catalogação na Publicação (CIP)

\section{C578 Cirne, Ademar}

Racismo religioso em escolas da Bahia:

autoafirmação e inclusão de crianças e jovens de

terreiro / Ademar Cirne. - Ilhéus, BA: Editus, 2020.

203 p. : il. - (Transfluência)

Referências: p. 177-183.

ISBN: 978-65-86213-16-4

1. Racismo. 2. Crianças - Religião. 3.

Racismo na educação - Bahia. 4. Candomblé. 5.

Multiculturalismo. I. Título.

CDD 305.8

\section{Elaborado por Quele Pinheiro Valença CRB 5/1533}

\section{EDITUS - EDITORA DA UESC}

Universidade Estadual de Santa Cruz

Rodovia Jorge Amado, km 16 - 45662-90o - Ilhéus, Bahia, Brasil

Tel.: (73) 3680-5028

www.uesc.br/editora

editus@uesc.br

EDITORA FILIADA À

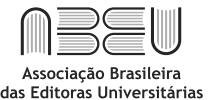




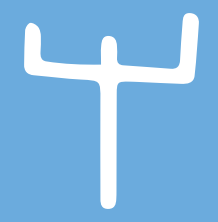




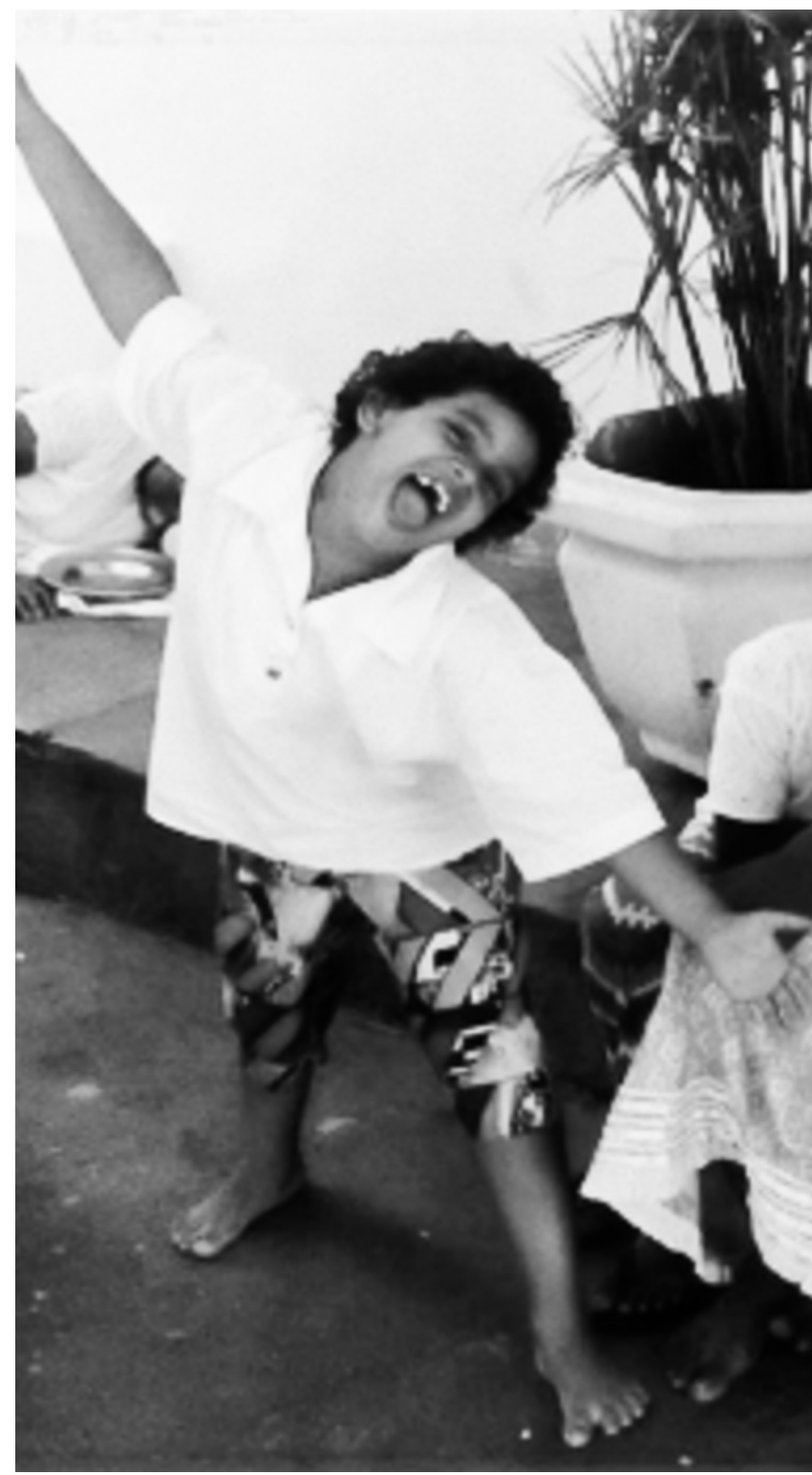




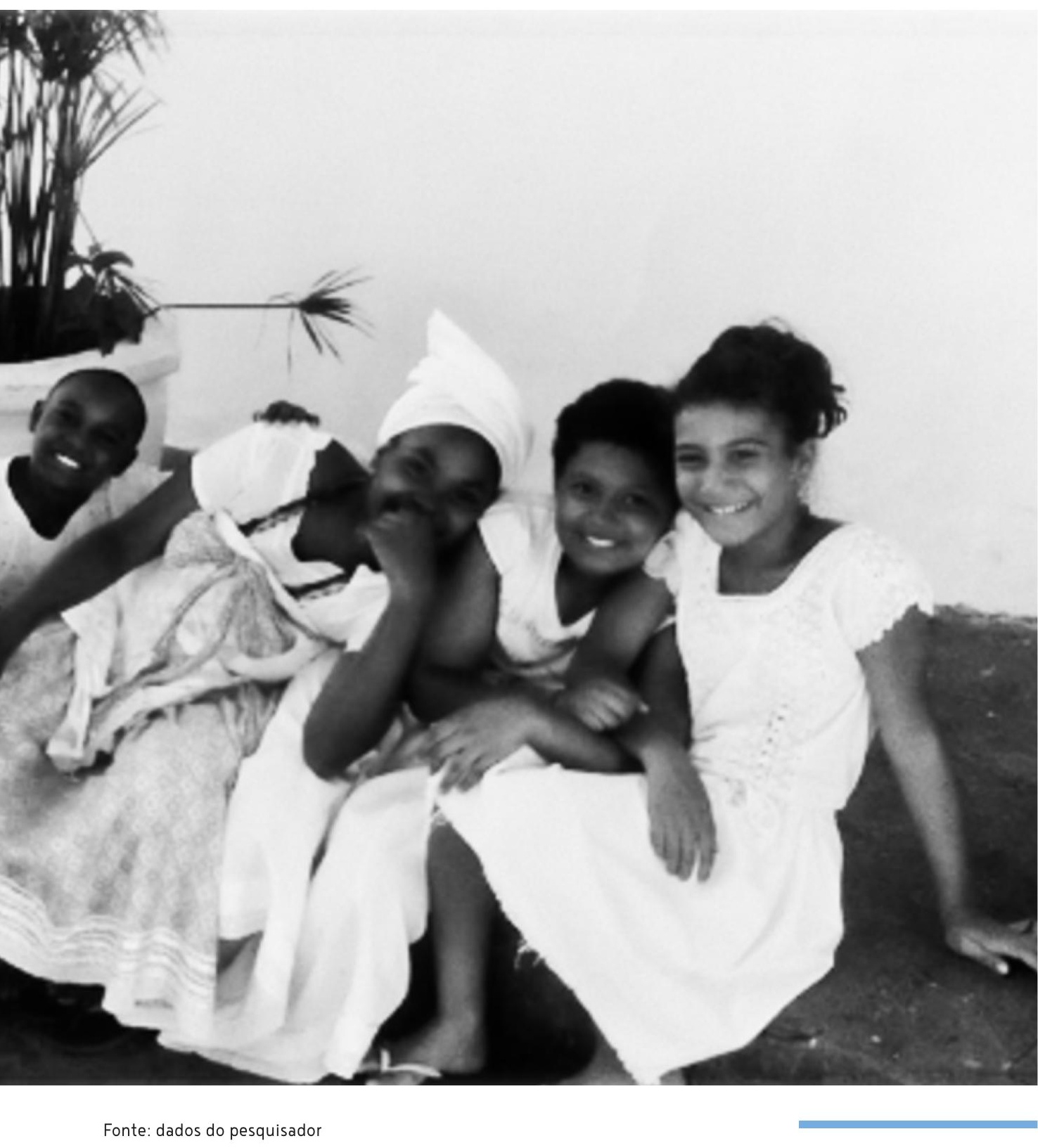



Um abraço negro, um sorriso negro traz felicidade, [...] negro é a raiz da liberdade.

Dona Ivone Lara 



\section{dedicatória}

Dona Celina Guiomar de Oliveira, minha querida Vó Celina (in memoriam), que na sua firmeza, cuidado e generosidade marcou profunda e carinhosamente minhas memórias da infância. 


\section{sumário}

17 apresentação|Kabengele Munanga

25 Introdução

33 Narrativas histórico-acadêmicas da África e a negação de sua importância

49 Movimento negro, racismo religioso e multiculturalismo

63 O eu no outro: reconhecendo-me negro

131 Pesquisa de campo: dando voz às crianças de Candomblé

138 Terreiros llê Axé Odara e llê Axé Oxumarê

143 Entrevistas: sacerdotes e crianças e jovens dos terreiros

143 Sacerdotes

149 Crianças e jovens do llê Axé Odara e llê Axé Oxumarê 


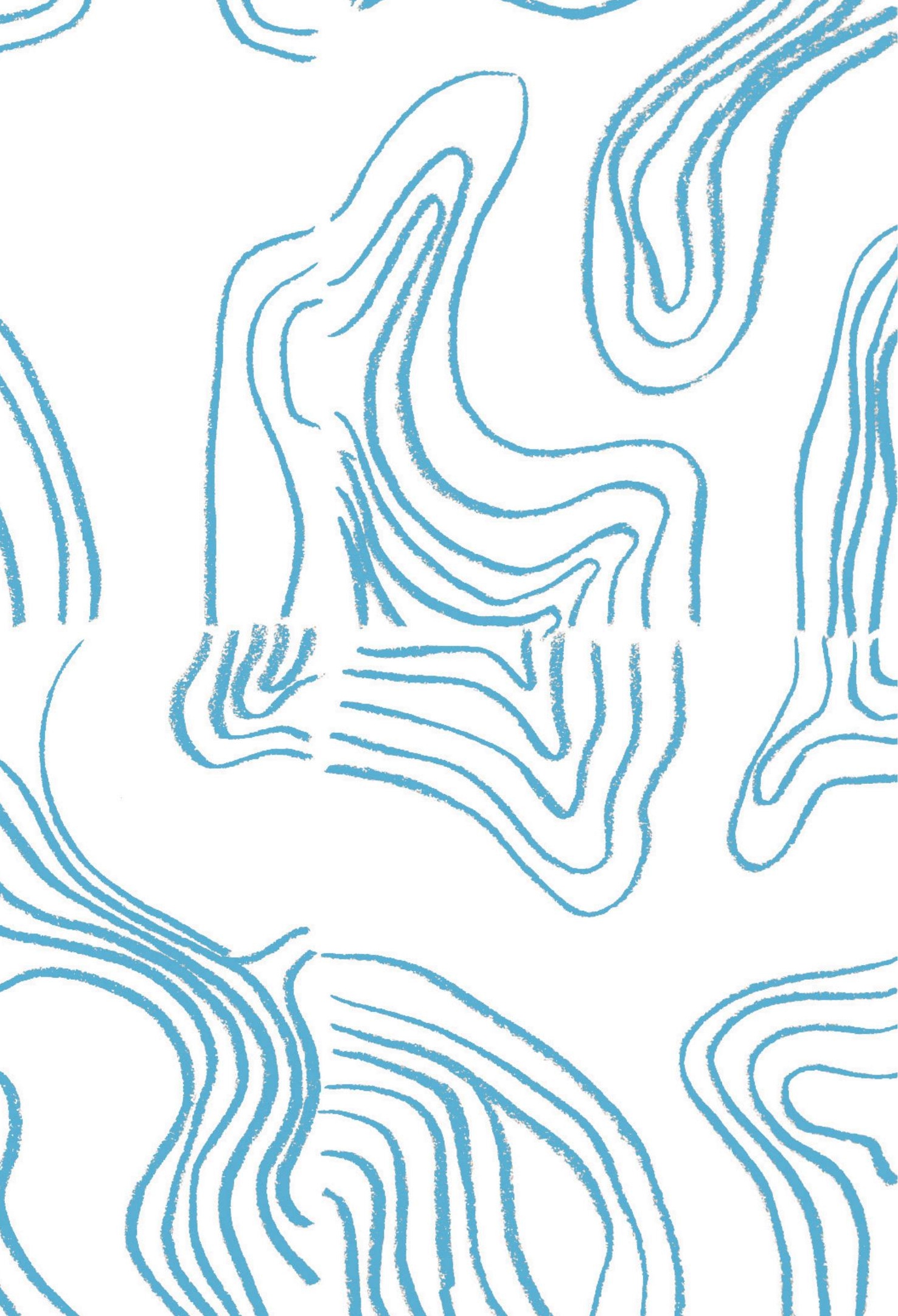


152 Crianças e jovens do llê Axé Odara

159 Crianças e jovens do llê Axé Oxumarê

166 O que dizem as crianças candomblecistas

171 Palavra final: resistência

177 referências

185 apêndice

189 posfácio| Cynthia Cy Barra e Laura Castro

203 sobre o autor 


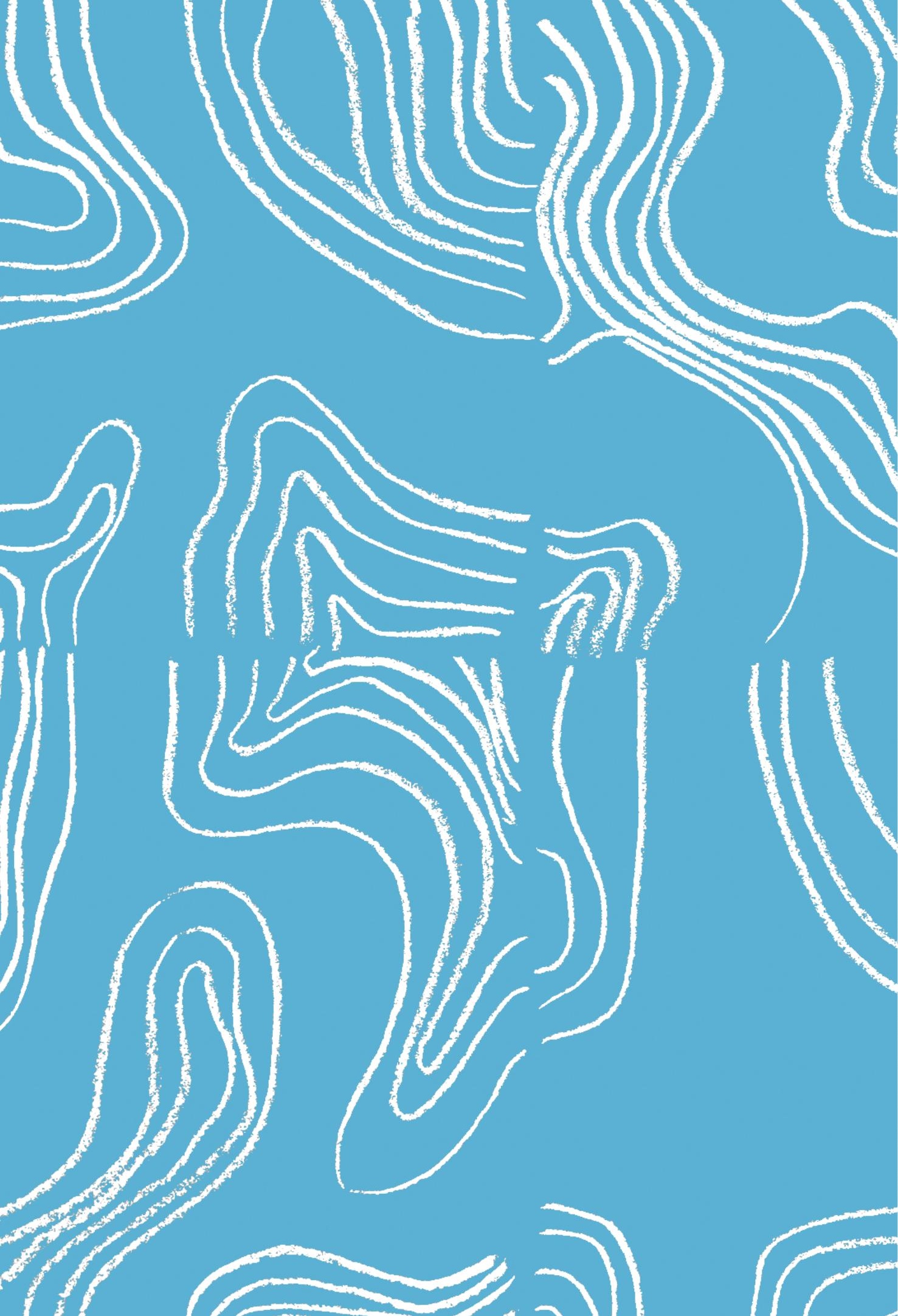




\section{apresentação}

Lembrar-se-ia das cenas de violências e horrores que aconteceram há cerca de 400 anos, quando milhões de seres africanos foram deportados para as Américas, onde serviram como mão de obra escravizada. Na travessia do Atlântico, muitos deles morreram de fome, maus tratos e banzo.

A bordo dos tumbeiros, havia capelas onde começaram a ser batizados para iniciar o processo de sua conversão ao cristianismo, de acordo com as recomendações do Vaticano. O que significa que o processo de destruição das religiões de matriz africana começou antes dos portadores dessas religiões pisarem nas terras de destino. Pelo batizado, seus nomes étnicos foram substituídos pelos nomes do calendário cristão, consequentemente, destruindo suas identidades étnicoculturais simbolizadas pelos nomes originais. Chegando ao destino, o processo de destruição de suas identidades religiosas iniciado a bordo dos tumbeiros se radicalizou drasticamente pela implantação de leis e proibições policiais que os impediam, sob pena severa, de continuar a cultuar seus deuses.

O resultado final desse processo de desenraizamento teria sido a perda total da identidade religiosa desses africanos e seus descendentes de ontem e de hoje, sob o rolo compressor do sistema escravista. Surpreendentemente, essas religiões resistiram e se tornaram religiões brasileiras 
aceitas e frequentadas por brasileiras(os) de todas as cores, brancas(os) e negras(os).

A questão que se coloca é saber como conseguiram resistir a ponto de se tornar um dos patrimônios culturais brasileiros? Onde estaria escondido o segredo dessa resistência que surpreende o mundo diante de tanta força opressiva e destruidora pela qual passaram os africanos escravizados e seus descendentes? Tudo deixa a crer que, apesar da violência à qual foram submetidos, eles não abriram mãos da defesa de sua dignidade humana, de sua liberdade e identidade.

O núcleo duro dessa resistência foi sua religião, por onde passa sua visão do mundo, da natureza, do cosmos, ou seja, sua visão global da existência. Visão essa que costura as relações entre os seres humanos e o mundo animal e vegetal, entre povos e nações, entre povos e o criador supremo que existe em todas as culturas e sociedades africanas, certamente com nomes diferentes, de acordo com a diversidade linguística continental. Eles não abriram mãos de suas religiões, cuja relação dialética com a estrutura política, econômica e social é fundamental. Por isso, a religião constitui o núcleo duro a partir do qual se organizou a resistência dos outros setores da cultura negra, como as artes visuais e não visuais, música, dança, culinário, plantas medicinais, entre outros.

Mas, a questão que se coloca é saber como isso foi possível diante das relações assimétricas de poder entre escravizados e seus escravizadores? Os escravizados não podiam enfrentar frontalmente seus "senhores" por causa da desigualdade entre as forças; pois uns tinham capatazes e armas de fogo, e outros, tratados como animais, estavam 
desarmados. Eles descobriram uma saída ao desenvolver uma estratégia muito inteligente de relacionamento entre forças desiguais que consistiu em driblar os obstáculos sem enfretamento físico frontal. Descobriram que havia semelhanças entre características dos santos católicos e alguns de suas divindades, Orixás ou Inkissi que adotaram como seus protetores ou correspondentes para se proteger da violência dos opressores, numa espécie de convivência e cumplicidade supostamente harmoniosa. Assim, quando havia batidas policiais nos barracões, os opressores encontravam, ali, figuras de santos católicos, altares e velas acesas e se retiravam tranquilamente, acreditando que eles estavam cultuando santos católicos, enquanto os assentamentos de seus orixás estavam escondidos em algum lugar nesse espaço de convívio de diversidades não proclamado.

Além de conviver pacificamente com o Deus e santos cristãos, os africanos e seus descendentes escravizados abriram também, em seus terreiros, um espaço de convivência com os deuses da terra, os chamados caboclos, que eles começaram a cultuar para construir também com eles uma relação pacífica entre forças vitais originárias da terra Brasil e eles estranhos deportados, pois os caboclos não eram conhecidos na África.

Tudo isso foi chamado sincretismo religioso pelos estudiosos das religiões africanas no Brasil. Mas tem de ficar claro que não se trata de síntese no sentido de uma nova religião nascida dos contatos entre religiões de matriz africana e religiões cristãs. Trata-se de um pluralismo religioso caracterizado pelas trocas simbólicas e convivência num mesmo espaço social e geográfico. Nada de síntese no sentido de $A$ mais $B$ é igual a $C(A+B=C)$; nada de caldeirão, 
mas simplesmente de uma justaposição de religiões diferentes no mesmo espaço.

Uma outra característica das religiões de matriz africana é o fato de não serem religiões proselitistas ou universalistas que criaram muitos conflitos na história da humanidade. Creio que tudo mundo se lembra da história das inquisições na Península Ibérica nos séculos XIV e XV; das guerras santas islâmicas ou Jihad; das cruzadas; dos conflitos entre ortodoxos, católicos e muçulmanos em Kosovo; dos conflitos entre católicos e protestantes na Irlanda do Norte. Mas não temos registros históricos sobre conflitos religiosos na África antes da ocupação colonial, a não ser os conflitos entre religiões universalistas importadas na África, como o caso da Nigéria, onde esses conflitos entre o Sul católico e o Norte islâmico desestabilizam o processo de construção da paz e da nacionalidade daquele país. Me parece que os indícios desses conflitos estão começando a surgir nos países africanos entre religiões neopentacotistas ou evangélicas de penetração recente e religiões africanas tradicionais, da mesma maneira que estão surgindo no Brasil em relação às religiões brasileiras de matriz africana. Era de esperar.

A explicação estaria no fato de as religiões tradicionais africanas terem um caráter familial e não universalista em busca da clientela. São religiões que sabem integrar os diversos e os diferentes num quadro familial de convivência, sem hierarquização entre homens e mulheres, pois as mulheres e os homens têm o mesmo estatuto pleno de sacerdote. Ou seja, um babalorixá, ou pai de santo, e uma lalorixá, ou mãe de santo, são iguais em seus estatutos de sacerdote. Heterossexuais e homossexuais convivem como irmãos e irmãs sem exclusão homofóbica existente em outras religiões do 
mundo. Políticos de todas as tendências ideológicas, que às vezes se apresentam durante as campanhas eleitorais em busca de votos, são recebidos igualmente nos terreiros de Candomblé ou de Umbanda, pelo que já observei pessoalmente.

Mas uma coisa posso me arriscar para afirmar que os espaços de cultos religiosos de matriz africana não são reservas eleitorais de alguns partidos políticos, porque essas religiões têm uma certa neutralidade partidária. No entanto, sua clientela é cobiçada pelas religiões ditas evangélicas. Daí todas as perseguições e campanhas de difamação que demonizam e satanizam essas religiões visando sua destruição total. O que muitos denominam intolerância religiosa. Mas o que buscam as vítimas da chamada intolerância não é ser tolerada, pois tolerar subentende que há um grupo de pessoas ocupando uma posição superior e que aceitam que as outras, numa posição inferior, possam ter a liberdade de cultuar seus deuses.

Visto deste ângulo, eu considero impróprias as palavras tolerar e intolerar, pois ninguém luta, trabalha e constrói para ser tolerado por outro, mas no mínimo para ser respeitado e tratado igualmente em termos de direitos humanos fundamentais, entre os quais se inclui a liberdade de crenças, cultos e religiões. $O$ que as religiões de matriz africana vivem no Brasil, hoje, não é a intolerância em si. É uma discriminação racial embutida no racismo à brasileira e que visa sua eliminação total do universo religioso brasileiro, que é por definição plural. É um crime inominável que deve ser combatido e condenado pelas leis do país. 
Aqui se coloca a responsabilidade do Estado brasileiro como um estado de direito. Um Estado laico é neutro religiosamente, pois não há religião do Estado como aconteceu e acontece em alguns países do mundo. Mas ser neutro não significa ser indiferente diante das discriminações e conflitos religiosos, pois o Estado tem obrigações definidas nas leis do país para garantir a liberdade de crença, culto e religiões de todos os cidadãos e todas as cidadãs que fazem parte dos diretos fundamentais contidos na Declaração Universal dos Diretos Humanos, sem tomar partido.

O livro "Racismo Religiosos em Escolas da Bahia", da autoria de Ademar de Oliveira Cirne Filho, se debruça justamente sobre a existência do racismo nas escolas da Bahia e suas consequências no processo de construção da identidade religiosa de jovens negros e negras que frequentam essas escolas, de sua autoestima que impacta sobre os resultados de sua aprendizagem escolar. A partir de uma rica pesquisa de campo, baseada numa dupla experiência como professor de história do Brasil na educação básica pública e privada e como praticante membro da Comunidade Religiosa llê Axé Oxumaré, onde ocupa o cargo de Ogã de lemanjá, o autor aponta a importância de investir numa educação multicultural que valoriza a riqueza da diversidade religiosa brasileira. Isto é, uma educação antirracista que foge do modelo eurocêntrico colonizante e alienante dominante e do fundamentalismo religioso que está sendo introduzindo por algumas religiões neopentacotistas ou evangélicas que tentam destruir as religiões de matriz africana praticando não a intolerância religiosa, mas sim uma discriminação racial religiosa sem ambiguidade. 
Com base em sua rica experiência acima referida, ele aponta alguns caminhos e as possibilidades de trabalhar contra esse racismo religioso no espírito da Lei 10.639/03, que torna obrigatório o ensino da história, da cultura da África e de sua diáspora brasileira. Não há como entender a resistência cultural do negro no Brasil deixando de lado a religião que foi o núcleo duro dessa resistência e em torno do qual se organizaram outros setores da resistência, como as diferentes formas de artes. Mas estamos de acordo que a abordagem não deveria ser dogmática e litúrgica, mas histórica e cultural, pois as religiões são culturas e têm histórias. Satanizar algumas, inferiorizando-as, visando sua eliminação do mapa religioso brasileiro, como estão fazendo com as religiões de matriz africana, é uma prática racista que a obra de Ademar de Oliveira Cirne Filho analisa e discute, apontando a importância e o papel da educação, além das leis e das políticas afirmativas. Indo além da retórica e análise crítica em defesa das religiões de matriz africana no Brasil, ele convida seus leitores e suas leitoras a fazer uma nova leitura a partir de um universo empírico específico. Li e gostei e muito aprendi.

Kabengele Munanga

Setembro de 2020 



\section{1}

\section{introdução}

Esta obra é resultado de uma pesquisa desenvolvida no âmbito do Programa de Pós-Graduação em Ensino e Relações Étnico-Raciais da Universidade Federal do Sul da Bahia - PPGER/UFSB, como requisito para obtenção do título de Mestre, cuja dissertação foi defendida em julho de 2019.

O racismo religioso sofrido pelas crianças e jovens iniciados nas religiões de matriz africana, particularmente nos espaços de educação formal, é a motivação para este autor, que tem sua história de vida vinculada, por um lado, a crianças e jovens no espaço de educação formal, como professor, e, por outro lado, a crianças e jovens de Terreiro, espaço que frequenta ${ }^{1}$ por sua opção religiosa, ocupando a posição de Ogã².

Portanto, em primeiro lugar, pede-se licença aos iniciados mais velhos e apresenta-se gratidão aos que contribuíram diretamente para essa obra, espcialmente aos BabaIorixás Babá Pecê, do Terreiro llê Axé Oxumarê, localizado no município de Salvador/Bahia, e Pai Gildo, do Terreiro llê Axé Odara, em Itabuna/Bahia, que cederam os espaços sagrados para realização da pesquisa. Gratidão às crianças e jovens 
3. Nome usado nas religiões de matriz africana para os colares que os (as) filhos (as) de santo recebem no seu ato de iniciação.

4. Turbante usado na cabeça dos religiosos de matriz africana, Ojás variam de acordo com o grau de iniciação do religioso. destas casa sagradas, principais protagonistas da pesquisa e, portanto, desta obra.

O racismo religioso se constitui em violação dos direitos do cidadão e merece análise pois, embora o Estado brasileiro seja laico desde 1891 (BRASIL, 1891), conforme estabelece a primeira constituição republicana do país, reafirmado na constituição cidadã (BRASIL, 1988), atualmente em vigor, a liberdade religiosa não é uma realidade. Na verdade, as religiões de matriz africana e seus membros continuam a ser injustamente discriminados, afrontando o princípio da igualdade, que se constitui em um dos fundamentos da República Federativa do Brasil.

Atualmente, no Brasil, as ações de racismo religioso, principalmente direcionadas aos povos tradicionais de matriz africana, têm se ampliado consideravelmente, ocorrendo invasões e destruição de muitos terreiros de Candomblé e centros de umbanda; expulsão de religiosos de matriz africana das suas casas e dos seus espaços sagrados e perseguição de religiosos nas ruas quando são identificados como praticantes dos cultos de matriz africana, com seus trajes, suas guias ${ }^{3}$ e seus ojás ${ }^{4}$ na cabeça. Essas ações ocorrem também, com frequência, nos espaços escolares, atingindo especialmente crianças e jovens de matriz africana, gerando um desconforto a estes que, na maioria das vezes, se veem obrigados a esconderem sua identidade religiosa para continuarem frequentando a escola, ou mesmo abandonam os estudos por não suportarem a ação racista e intolerante sobre eles.

Além da pesquisa direta, as leituras e observações realizadas pelo autor revelam que tais ações praticadas 
contra as crianças e jovens de religiões de matriz africanas extrapolam, em muito, uma simples prática de intolerância religiosa, sendo identificadas como uma prática de racismo religioso, já que tais situações são sempre recorrentes e acompanhadas de ódio e violência contra religiosos que, na sua maioria, são negros.

Vale destacar que essas atitudes de racismo religioso continuam acontecendo nos espaços de educação formal, mesmo depois de mais de 17 anos que foi sancionada a Lei 10.639 (BRASIL, 2003, s/p), que torna obrigatório, nas escolas de ensino básico, o conteúdo referente à História da África e da Cultura Afro-Brasileira citada a seguir:

\footnotetext{
Art. 26-A. Nos estabelecimentos de ensino fundamental e médio, oficiais e particulares, torna-se obrigatório o ensino sobre História e Cultura Afro-Brasileira. $\S 1^{\circ} \mathrm{O}$ conteúdo programático a que se refere o caput deste artigo incluirá o estudo da História da África e dos Africanos, a luta dos negros no Brasil, a cultura negra brasileira e o negro na formação da sociedade nacional, resgatando a contribuição do povo negro nas áreas social, econômica e política pertinentes à História do Brasil. § $2^{\circ}$ Os conteúdos referentes à História e Cultura Afro-Brasileira serão ministrados no âmbito de todo o currículo escolar, em especial nas áreas de Educação Artística e de Literatura e História Brasileiras.
}

Apesar das legislações citadas serem resultado de mobilizações e reivindicações do movimento negro organizado, ainda não se observa a sua aplicação na maior parte dos espaços de educação formal. Ao contrário, o que se observa é a continuidade de práticas discriminatórias às comunidades de terreiros, atingindo principalmente as crianças e os jovens, o que aponta para a necessidade de 
ampliar e fortalecer a organização de ações para enfrentamento desse problema, assim como revela a importância de se produzir, publicar e estimular a leitura sobre o tema.

Além de obras como a que se apresenta aqui, é relevante produzir e difundir instrumentos didáticos pedagógicos, que contribuam para elevar a autoestima desse grupo social e para sua afirmação sociorreligiosa, bem como ações de decolonização dos currículos das escolas de educação básica, à luz da promulgação da Lei n. 10.639 (BRASIL, 2003); do Estatuto da Igualdade Racial (BRASIL, 2010); do Estatuto da Igualdade Racial e de Combate a Intolerância Religiosa do Estado da Bahia (BAHIA, 2014) e do Plano Nacional de Implementação das Diretrizes Curriculares Nacionais para Educação das Relações Étnico-raciais e para o ensino de História e Cultura Afro-Brasileira e Africana (BRASIL, 2013).

Como referência histórica, a presente obra analisa o processo de colonização imposto aos países dominados pela elite europeia, durante todo período colonial e neocolonial, que não acaba com a expulsão dos dominadores, pois a sua ideologia permanece presente na educação brasileira, silenciando os estudos sobre a cultura afro-brasileira, com o pensamento eurocêntrico predominando nos currículos escolares até os dias atuais.

Diante da constatação de que não ocorreram mudanças no currículo das escolas após a implantação da Lei n. 10.639/2003, esta temática foi objeto de pesquisa pelo autor, objetivando analisar a diversidade da sociedade, procurando, por meio de um modelo de educação fundamentado nos princípios do multiculturalismo crítico, contribuir 
para a construção de uma sociedade cada vez mais justa e igualitária, onde os espaços de educação formal não mais tratem as crianças de religiões de matriz africana de forma preconceituosa e racista.

Ressalta-se a importância do estudo do continente africano e da sua história, o processo de colonização da África, assim como o início do processo de transferênciados negros africanos para o continente americano, por meio do tráfico negreiro, amplamente abordados por alguns teóricos que estudaram a temática, dentre eles Verger(2002), Albuquerque e Fraga Filho (2006), Bastide (2001) e Carneiro. (2002).

Esse resgate histórico embasou o problema norteador da pesquisa que gerou esta obra, ou seja, a percepção, a partir da visão das crianças e jovens de terreiro, de como eles sofrem o racismo religioso no ambiente escolar e como estas ações têm afetado a construção de sua identidade religiosa, sua autoestima e sua vida.

Para melhor compreensão do leitor, este livro está organizado em capítulos. Em "Narrativas histórico-acadêmicas da África e a negação de sua importância", é apresentado o contexto histórico da formação neocolonial do mundo africano e americano no século XIX, bem como de que forma a perspectiva eurocêntrica impôs o domínio e a subalternidade a estas regiões do mundo, e a resistência da população negra escravizada para conseguir manter a unidade e garantir a sobrevivência e liberdade. Essa narrativa teórico-metodológica visa o entendimento da origem do processo de racismo religioso sofrido pelas crianças e jovens de terreiro. Nessa parte explicita-se a base conceitual que 
norteou o trabalho e, também, são descritos os procedimentos metodológicos adotados.

No capítulo "Movimento negro, racismo religioso e multiculturalismo", apresenta-se a trajetória do movimento negro no Brasil desde a sua formação e da abordagem do racismo religioso em sua pauta reivindicatória, analisando sua importância na construção das políticas públicas de inclusão da população negra. Trata-se, também, da importância de uma educação multiculturalista para efetivação destas políticas públicas na escola.

O capítulo "O eu no outro: reconhecendo-me negro" consiste no memorial do autor, sua trajetória pessoal e profissional, com relatos sobre a infância até os dias atuais, descrevendo o processo de construção de identidade e pertencimento, a sua origem afrodescendente, o que motivou o estudo e a construção dessa obra com esta temática. Esse relato dialoga tanto com a história do movimento negro, como com alguns aspectos teórico-metodológicos que embasaram a pesquisa realizada.

O capítulo "Pesquisa de campo: dando voz às crianças de Candomblé" relata a pesquisa direta, realizada em espaços religiosos de matriz africana, por meio de entrevistas e oficinas com crianças e jovens pertencentes a essa religião, com a presença de autoridades religiosas dos terreiros, assim como as observações em instituições educacionais. Neste capítulo, descreve-se o perfil das crianças e jovens, e faz-se uma comparação dos seus modos de viver entre os espaços religiosos e as escolas, evidenciando como eles apresentam comportamentos distintos nos diferentes ambientes. 
O último capítulo, "Palavra final: resistência", apresenta as considerações finais e sinaliza algumas possibilidades de outras pesquisas que tratem do racismo religioso, na perspectiva de superar essa problemática presente na sociedade brasileira. 



\section{Narrativas histórico- acadêmicas da África e a negação de sua importância}

Os africanos passaram pelo processo de escravização imposto pelos colonizadores europeus que, de forma violenta, retiraram os negros do continente africano, romperam seus laços familiares, submeteram estes a péssimas condições de vida durante a viagem nos navios negreiros, além de terem os escravizado, durante quase 400 anos. Diante de toda essa vida angustiante, viam-se impelidos a agirem de forma violenta, em busca de sua libertação, a exemplo da Revolta dos Búzios (Conjuração Baiana), em 1789, e Revolta dos Malês, em 1835, das construções de quilombos, ou das ações, também violentas, dentro dos engenhos contra os seus senhores, feitores e capitães do mato.

Apesar de tudo isso, o povo escravizado resistiu e reconstruiu sua identidade cultural e religiosa, utilizando os espaços sagrados (terreiros de Candomblé), nos quais as mais velhas senhoras reuniam os mais novos para refazer os 
laços familiares, reconstruindo as bases sociais dos grupos africanos.

A história do povo de santo construida no Brasil está diretamente associada às Mães de Santos ou Sacerdotisas, principalmente no que refere à sustentação moral e espiritual das famílias de Terreiro, condição ainda presente no Brasil até os dias de hoje. Outrora, quando da escravidão, negras e negros, que ao serem comercializadas(os) e enviadas(os) para os mais diversos destinos, vendo, assim, destruídos os seus núcleos familiares consanguíneos, bem souberam restituir laços afetivos a partir dos Terreiros de Candomblé, sobretudo pela força afetiva exercida pelas mulheres.

Havia também práticas de resistência mais estratégicas, como a prática de abortos, para que seus filhos não nascessem e viessem a ser mais um instrumento de acumulação primitiva do capital dos senhores, por meio do trabaIho escravo, vítimas do processo de diáspora africana que chegou a trazer para o Brasil, via tráfico negreiro, mais de quatro milhões de negros que, escravizados, eram utilizados em vários tipos de funções, desde trabalhar na lavoura, nos serviços domésticos e até de ganho, tendo uma carga absurda e desumana de trabalho.

Ainda nos dias de hoje, em que pese não mais ser vivenciada a escravidão, homens e mulheres negras restituem seus afetos, as suas dignidades e os seus sentimentos de pertencimento no seio dos terreiros, atualmente, verdadeiros quilombos urbanos contemporâneos, espaços em que os mais velhos, especialmente a figura feminina, nas 
diversas funções em que atuam, transmitem hábitos, valores e, sobretudo, a identidade ancestral.

A seguir, uma ilustração de mulheres do Terreiro llê Axé de Ogum, no município de São Francisco do Conde, Bahia (Figura 1).

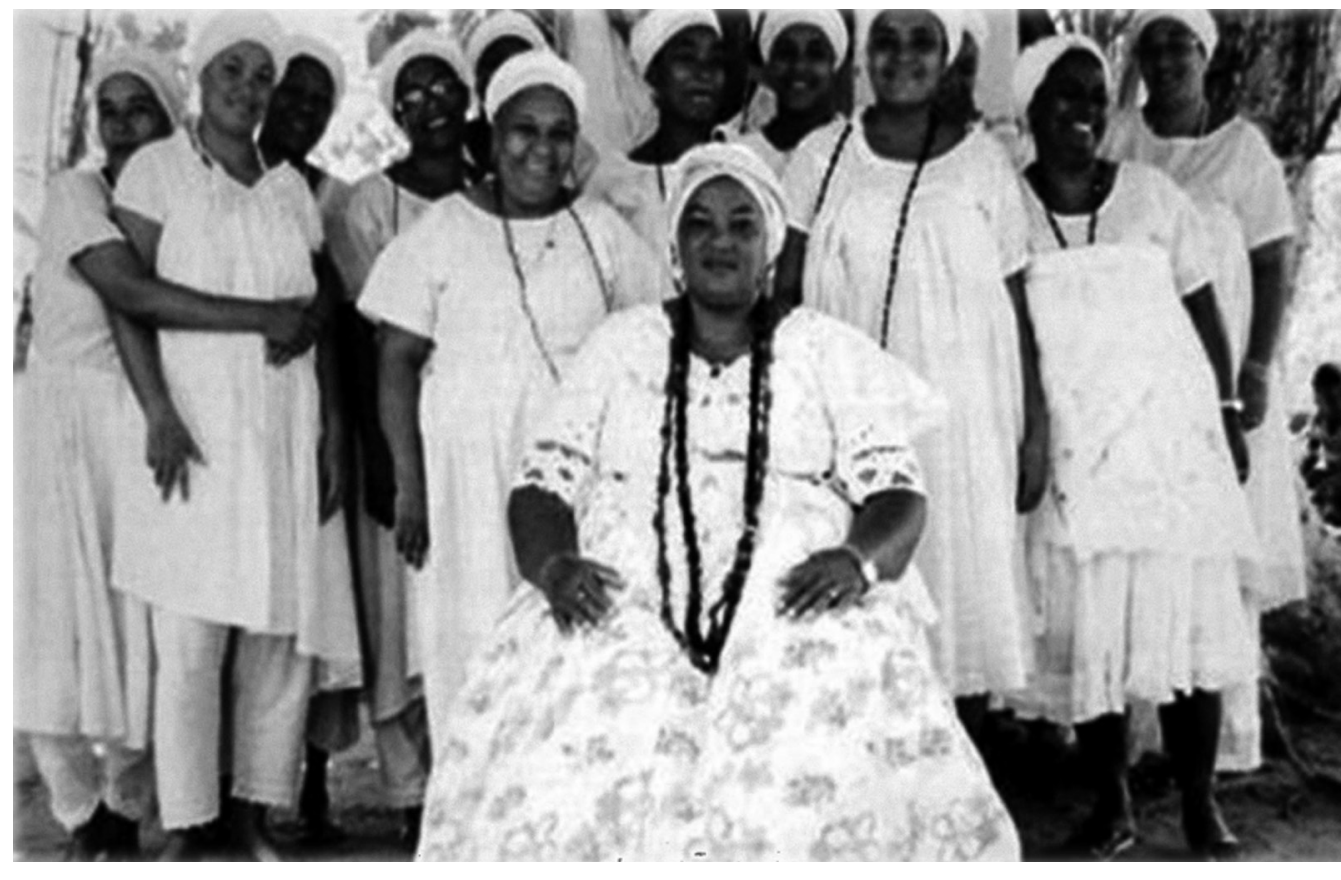

Fonte: Mulheres de Axé (REZENDE, 2013).

Figura 1

Família llê Axé de Ogum. São Francisco do Conde-Ba, 2013 
Conforme relatado acima, por meio do tráfico de escravos, a África, continente onde surgiu a humanidade e a civilização, de acordo com diversos sociólogos e/ou historiadores é inegavelmente significativa na formação do povo brasileiro, mas, apesar disso, tem uma história constantemente negada no espaço formal de educação vigente no Brasil, baseada no pensamento eurocêntrico. A essa história foram imputados, até mesmo, elementos que não fazem parte originalmente de sua cosmologia, como a figura do diabo. O próprio nome é fruto de relações exógenas e sua etimologia é de difícil caracterização (KI-ZERB, 1972 apud SILVÉRIO, 2013).

A tradição familiar africana é um dos instrumentos de compreensão das articulações de pequenas e/ou grandes redes de sociabilidade entre grupos étnicos com algum tipo de afinidade, que geravam riscos e benefícios na "disputa pelo acesso aos rios, pelo controle sobre estradas ou rotas e pela construção de impérios e reinos importantes, tais como Império Egípcio e Mali, Reino Kongo, Povo Banto, Iorubá, Sudanês e Moçambique" (ALBUQUERQUE; FRAGA FILHO, 2006, p. 14). Os conflitos entre eles fizeram surgir uma escravidão doméstica no continente africano, influenciada por vínculos de parentesco, o que possibilitava a assimilação completa de indivíduos e grupos de escravos.

Essa concepção tradicional, de ampliação dos limites demarcadores dos vínculos parentais na construção de amplas unidades familiares permanece viva em território brasileiro, ainda que reinventada a partir da fusão com outras tradições, sobretudo as indígenas (ALBUQUERQUE; FRAGA FILHO, 2006, p.15). 
As navegações europeias e as trocas comerciais estabelecidas com os africanos no século XVI deram origem ao sistema colonial-escravista brasileiro, o qual se fundamentou no trabalho forçado de cerca de 15 milhões de homens e mulheres "arrancados de suas terras" (REIS; GOMES, 1996). Durante mais de três séculos, a relação entre tráfico de africanos, captura de indígenas no interior e utilização de mão de obra escravizada nas atividades laborais foi fundamental para o desenvolvimento da economia portuguesa, como descrevem Albuquerque e Fraga Filho.

\begin{abstract}
A retirada violenta de africanos de suas comunidades, conduzidos para trabalhar como escravos em terras distantes, foi a solução encontrada pelas potências coloniais europeias para povoar e explorar as riquezas tropicais e minerais das colônias no Novo Mundo. A colônia portuguesa (o Brasil) dependia de grande suprimento de africanos para atender às necessidades crescentes de uma economia carente de mão-de-obra. A migração transatlântica forçada foi a principal fonte de renovação da população cativa no Brasil, especialmente nas áreas ligadas à agricultura de exportação, como cana-de-açúcar. Submetida a péssimas condições de vida e maus-tratos, a população escrava não se reproduzia na mesma proporção da população livre. Era alto o índice de mortalidade infantil e baixíssima a expectativa de vida.
\end{abstract}

O tráfico negreiro realizado pelos países da Europa durante o período do Antigo Regime foi uma das mais importantes formas de acumulação de capitais da burguesia comercial, construindo as condições para consolidação do sistema capitalista após a eclosão da revolução industrial no século XVIII (SILVA, 2012). 
Ocorre que, apesar de tamanha desumanidade durante os séculos de cativeiro, a população africana e afro-brasileira conseguiu manter um intenso processo de resistência, em vários âmbitos e, conforme Schwartz (2001, p. 219-220),

A recalcitrância cotidiana, a lentidão no ritmo de trabalho e a sabotagem eram, provavelmente, as formas mais comuns de resistência, ao passo que a autodestruição por meio de suicídio, infanticídio ou de tentativas manifestas de vingança eram as mais extremas no sentido pessoal. No Brasil, os exemplos mais drásticos de atos coletivos foram as inúmeras rebeliões de escravos ocorridas no início do século XIX na Bahia, porém rebeliões como a dos malês, em 1835, foram episódios verdadeiramente extraordinários. A forma mais comum de resistência escrava no Brasil colonial era a fuga e um dos problemas característicos do regime escravista brasileiro era a existência contínua e generalizada de comunidades de fugitivos, que recebiam diversas denominações: mocambos, ladeiras, magotes ou quilombos.

Prova disso é que, mesmo com péssimas condições de vida e alto índice de mortalidade infantil, as formas de resistências construídas pelas negras e negros garantiram a perpetuação do grupo social, permitindo que a população brasileira, na época da independência, fosse composta, de acordo com Viotti da Costa (1998, p. 19), por

[...] aproximadamente um milhão e 347 mil brancos e 3 milhões e 993 mil negros e mestiços entre escravos e livres. Em certas áreas, os cativos constituíam maioria absoluta. Sua distribuição era irregular, em alguns pontos mais concentrada, como Pernambuco, Bahia, Minas Gerais e Rio de Janeiro. Os caminhos da escravidão seguiam as etapas da economia. 
Percebe-se que a população negra no Brasil está concentrada nas regiões onde ocorreu a maior concentração de atividade econômica para exportação, já que quase toda mão de obra utilizada nesse processo produtivo e extrativista era composta pelos escravos negros.

Vê-se, portanto, que não se pode conceber a escravidão sem a forte presença de uma resistência que perpassou todos os aspectos da vida social e cultural dos cativos. Entretanto, consoante Reis e Gomes (1996), isso não significa que todo o processo de resistência teve como princípio a criação de uma sociedade alternativa livre.

A especialização das forças repressivas contra a resistência da população negra, inclusive as culturais, tem influência também no surgimento das Religiões de Matriz Africana no Brasil, em meio à proibição religiosa que se estabeleceu por conta da predominância das religiões de Matriz Judaico-cristã na colônia. Estas proibiam qualquer tipo de manifestação religiosa dos negros livres ou escravizados, o que fez surgir entre esta população a perspectiva do sincretismo religioso que, dentro das senzalas, era usado para continuar reverenciando os deuses africanos (Orixás), sem que os senhores brancos percebessem o verdadeiro sentido da manifestação, como se pode verificar por meio do entendimento de Bastide (1971 apud SOARES, 2002 p. 45-75):

O assim chamado sincretismo resulta de três modalidades de relação: estrutural, cultural e sociológica. O africano leva o panteão católico, transbordante de santos e virgens-marias, a partir da relação entre os orixás intercessores e Olorum, deixando de lado, no entanto, a ideologia católica do "sofres aqui para gozar além". 
Portanto, ao menos no início, será a religião africana a purificar o catolicismo quando aceita o culto ao santo.

A vivência frequente do autor nas Casas de Religião de Matriz Africana nos últimos anos permitiu perceber, cada vez mais, como a ideia do sincretismo religioso foi uma estratégia da população negra para a manutenção dos seus princípios religiosos trazidos da África. Atualmente, as relações entre os orixás africanos e os santos da igreja católica podem até continuar existindo dentro dos terreiros, porém com uma distinção do que seja o orixá e o santo católico, dessa forma, já não é mais preciso esconder o orixá por trás de um santo.

É nesse contexto de resistência que as religiões de matriz africana aparecem como um dos principais elementos de socialização e educação para as crianças e jovens negros, que durante praticamente toda existência são tratados com indiferença e discriminação no seu cotidiano e, principalmente, no ambiente escolar, o que se constitui em racismo religioso.

Diversas pesquisas acadêmicas têm se dedicado ao estudo das relações existentes entre as religiões de matriz africana e a educação. Dentre estas, destacam-se as obras da professora Caputo (2012), que trata da relação que a escola formal estabelece com as crianças de terreiro. Em sua tese de doutorado, a autora relata o resultado de uma pesquisa feita durante cerca de 20 anos no Terreiro de Mãe Palmira, na Baixada Fluminense, no Rio de Janeiro, pela qual acompanhou o crescimento de, pelo menos, cinco crianças dos 4 aos 20 anos e suas relações com o ambiente escolar. Em outra obra, esta mesma autora trata de como se 
estabelece a relação do Candomblé com a educação formal, a partir de uma análise multiculturalista crítica (CAPUTO, 2013).

Dois livros da professora Eliane Cavalleiro, Do silêncio do lar ao silêncio escolar: racismo, preconceito e discriminação na educação infantil (CAVALLEIRO, 2000) e Racismo e antirracismos na educação: repensando a nossa escola (CAVALLEIRO, 2001), apresentam importantes considerações sobre a discriminação racial sofrida por crianças em sala de aula. Embora não tratem especificamente do racismo religioso, também evidenciam o problema vivenciado por esta população.

Além das já citadas, a obra As águas de Oxalá, de Beniste (2009), apresenta, de forma didática, os conceitos filosóficos fundamentais para o entendimento do Candomblé, utilizando-se, inclusive, no texto, da linguagem Yorubá ${ }^{5}$ acompanhada de tradução, o que permite uma melhor compreensão do significado dessa prática religiosa. O trabalho do Professor Carneiro (2002) é de fundamental importância para compreensão do imenso processo de perseguição que os terreiros e seus frequentadores sofreram na Bahia durante a segunda metade do século XX, e das formas de organização e resistência dessas comunidades.

Em todo um contexto histórico de desvalorização e desrespeito às pessoas negras e suas manifestações religiosas, a despeito da valiosa contribuição desta raça para a formação brasileira e, contrastando com as alterações jurídicas que buscavam reverter este ultraje, verificadas no decorrer do tempo, a escola e a sociedade necessitam conhecer a respeito do racismo religioso, que persiste na 
sociedade brasileira; além disso, deve se engajar para superá-lo efetivamente.

A trajetória deste autor no movimento negro, assim como nos terreiros de Candomblé e na academia, o fez perceber uma necessidade de mudança no conceito original utilizado para definir o que acontecia com as crianças e jovens de terreiros no ambiente escolar. A princípio, chamava a discriminação a qual eles passavam de intolerância religiosa, acreditando se tratar apenas de uma reação às práticas e rituais que estes realizavam em seus espaços religiosos.

A maior convivência, tanto na academia como nos movimentos sociais e religiosos, assim como os contatos cada vez mais frequentes com as crianças e jovens nos terreiros, foi demonstrando que a questão era bem mais ampla e que a reação a estas crianças e jovens ia muito além da intolerância, na verdade, as ações contra estes grupos eram realizadas acompanhadas de muito ódio e raiva, associando estas pessoas sempre com concepções diabólicas e negativas.

Essas ações, na maioria das vezes praticadas contra as crianças negras, apresentam-se como uma prática racista, pois, não se trata apenas de tolerar ou não as práticas religiosas, mas sim de desqualificar, humilhar e segregar, provocando a separação radical entre brancos (católicos e ou evangélicos) e "negros macumbeiros, demoníacos". A leitura do trabalho de Araújo (2015) torna-se bem esclarecedora no que diz respeito a essa questão, o que se verifica na citação a seguir. 
Parto da hipótese de que as diferentes formas de intolerância religiosa infligidas contra pessoas ligadas às religiões afro-brasileiras no ambiente escolar (professores, alunos, gestores, funcionários, etc.) revelam uma forma de racismo. Tenho que admitir, porém, que a associação entre racismo e intolerância religiosa nem sempre foi admitida e dificilmente se mostrou evidente. E na maioria das vezes em que se percebeu essa correlação a discussão foi feita, majoritariamente no âmbito da academia. Todavia, essa discussão não pode se limitar à esterilidade das discussões meramente acadêmicas. Isso tem que mudar. É possível mesmo falar de algumas mudanças, que, contudo, ainda são tímidas, mas essa realidade começa a mudar. A mudança é lenta. Porém, já começa a se tornar perceptível. Um dos sinais dessa mudança está representado no fato de já se perceber uma compreensão e admissão da associação que há entre intolerância religiosa e o racismo, mudança que de início pode parecer muito elementar, contudo, carrega um simbolismo muito grande para as vítimas desse tipo de violência (ARAÚJO, 2015, p. 48)

As Figuras 2 e 3, a seguir, demonstram que o conceito de racismo religioso já vem sendo tratado de forma ampla, não só pela academia, mas também em eventos que mobilizam a sociedade no sentido de explicitá-lo e combatê-lo.

Essas imagens retratam como a sociedade civil organizada vem se mobilizando e promovendo uma série de atividades públicas, por meio das quais se expressa a indignação dos religiosos de matriz africana em relação às práticas de racismo religioso contra eles, e a citação de Nascimento (2017, p. 53) deixa claro a importância de entender todos estes ataques como práticas de racismo:

É fundamental ressaltar o entrecruzamento das relações entre racismo e práticas de violência, relacionado aos ataques às "religiões de matrizes africanas". E isto não é um detalhe, pois como 
lembra Lélia González (1983), o racismo é uma espécie de “neurose cultural", que se beneficia ao esconder seus sintomas, para - não aparecendo - fingir que não existe e, com isso, dificultando em muito o seu enfrentamento. Por isso, combater as práticas violentas contra as "religiões" de matrizes africanas é, também e sobretudo, combater a herança colonial do racismo que, embora tenha muitas maneiras de expressar-se, segue mascarada em nosso país.

Pode-se também observar na citação que boa parte das vezes que as casas de matriz africana são atacadas e resolvem prestar queixa nas circunscrições policiais as autoridades tentam desconsiderar o fato como crime de racismo e enquadrar como "briga de vizinhos", na tentativa de esconder o racismo do nossos país.

De acordo com o professor Wanderson Flor do Nascimento (2017), da UNB, historicamente falando, a primeira vez que a expressão racismo religioso apareceu no contexto acadêmico foi no trabalho de conclusão de curso de Lima (2012), por meio do qual ela afirma que

\footnotetext{
[...] o racismo pode ser definido como crenças na existência de raças superiores e inferiores. Dessa forma é passada a ideia de que por questões de pele e outros traços físicos, um grupo humano é considerado superior ao outro. Ao direcionar os argumentos racistas para as religiões, tem- se o racismo religioso, através do qual se discrimina uma religião. (LIMA, 2012 apud NASClMENTO, 2017, p. 55).
}

No contexto do movimento social, o conceito de racismo religioso aparece antes do acadêmico. Conforme apontam os estudos de Nascimento (2017), um dos primeiros estudiosos do tema, esta expressão aparece em 2009 , 
quando a Secretaria de Política de Promoção da Igualdade Racial - SEPPIR realiza uma reunião para discutir políticas públicas para povos e comunidades tradicionais. No seu artigo, Nascimento (2017, p. 55) afirma:

Mas a história do uso do conceito não começa aí. No ano de 2009 , Nilo Nogueira, então Assessor Técnico da Secretaria de Políticas para Comunidades Tradicionais da Secretaria Especial de Políticas de Promoção da Igualdade Racial, convocara uma reunião com lideranças dos povos de terreiro de vários lugares do Brasil para a discussão daquilo que deveria ter sido o Plano Nacional de Proteção da Liberdade Religiosa. Nilo Nogueira tem um longo histórico de comprometimento com os povos de terreiro e com o enfrentamento ao racismo. Na ocasião, duas das mais destacadas lideranças - Beatriz Moreira Costa, conhecida como Mãe Beata de Yemanjá e Valdina Pinto, conhecida como Makota Valdina apresentavam uma ideia com a qual elas já estavam trabalhando a algum tempo em seu ativismo. Elas diziam "Não queremos ser toleradas! Queremos ser respeitadas!". Nesse momento, a ideia de intolerância religiosa e seu enfrentamento pela promoção da tolerância se mostrava insuficiente ou inadequada para a perspectiva advogada por elas. É nesse momento, que a ideia já percebida por muitas pessoas que militavam contra o preconceito que atinge as comunidades de terreiro toma nome: quando elas afirmam que querem ser respeitadas, eu me pergunto o que motivaria tal desrespeito, e foi aí que apareceu a expressão: racismo, racismo religioso.

Precisa-se, no entanto, aprofundar os estudos e discussões sobre o conceito de racismo religioso para construir formas de combate a essa violência contra as comunidades religiosas de matriz africana, principalmente para desfazer a ideia que os racistas religiosos transmitem, a qual reduz estas instituições a espaços onde se praticam apenas rituais 
religiosos, não compreendendo ou rejeitando toda complexidade da vida social e da herança cultural dos povos africanos trazida para o Brasil e mantida viva nas casas religiosas de matriz africana. Essa visão limitada da problemática direciona para uma disputa meramente no campo religioso entre grupos de religiões diferentes, criando uma ideia falsa que esconde as práticas racistas, ocultadas na ideia de tolerância ou intolerância religiosa.

O capítulo 3, a seguir, trata da trajetória do movimento negro no Brasil e de sua relação com o combate ao racismo religioso, apontando o multiculturalismo crítico como possível caminho de uma educação antirracista. 



\section{Movimento negro, racismo religioso e multiculturalismo}

Apesar do movimento negro organizado somente colocar em pauta a questão do racismo religioso a partir do século XX, e admitir esta luta como uma das suas bandeiras principais, a exemplo de ações como luta para proteção legal dos terreiros, disputa na justiça pela manutenção das cerimônias de sacralização dos animais, não se pode negar que as resistências negras, muitas vezes realizadas por iniciativas políticas dos próprios espaços sagrados de matriz africana, remontam aos séculos XVIII e XIX, na luta pessoal de lyalorixás, como foi o caso de Mãe Aninha, fundadora do llê Axé Opô Afonjá, que foi ao Rio de Janeiro reivindicar, ao presidente Getúlio Vargas, a liberação da prática do candomblé, o que resultou na alteração da lei que, até aquele presente momento, tipicava a prática das religiões de matriz africana, bem como do espiritismo e de toda e qualquer sortilégio (BRASIL, 1890).

A cidade de Salvador, local de grande concentração de casas de candomblé e de população de maioria negra, 
foi um forte exemplo da perseguição aos terreiros de Candomblé pois, muito embora Vargas tenha descriminalizado - Candomblé, a repressão injusta e arbitrária não teve fim. Para exercer o culto religioso, o terreiro necessitava de um alvará de funcionamento expedido pela Delegacia Especial de Jogos e Costumes, órgão subordinado à Secretaria Estadual de Segurança Pública. A licença policial não oferecia nenhum tipo de proteção, mesmo sendo os responsáveis obrigados a comunicarem à polícia o dia em que iriam realizar o batuque.

O exercício do culto, sem pagamento de taxas e registros na polícia, só veio acontecer em 1976 (BAHIA, 1976), quando o então governador da Bahia, Roberto Santos, assinou um Decreto Estadual, liberando os terreiros da obrigatoriedade da licença da Delegacia de Jogos e Costumes.

Para compreender melhor o movimento negro brasileiro, o autor recorreu às pesquisas do professor e pesquisador Domingues (2007), segundo o qual este movimento apresenta-se em três fases distintas, durante a república brasileira, conforme descrito a seguir.

O primeiro momento da organização do movimento negro brasileiro se estendeu de 1889 até 1937, ou seja, da proclamação da República até o início do Estado Novo. Nesse período, começam a surgir as primeiras organizações sociais em defesa da população negra. O Estado de São Paulo é pioneiro, com a fundação do clube 13 de maio dos homens pretos, em 1902, e do Centro Literário dos Homens de Cor, em 1903. Outros Estados da federação, dentre eles Rio de Janeiro, Minas Gerais, Rio Grande do Sul e Bahia, também fundaram suas organizações sociais de defesa das causas 
dos povos negros. Foi nesse momento, também, que nasceu no Brasil as primeiras organizações negras compostas somente por mulheres, entre elas a Sociedade Brinco da Princesa, no ano 1925, em São Paulo, e a Sociedade de Socorro Mútuos Princesa do Sul, em 1908, em Pelotas/RS (DOMINGUES, 2007).

Outro fato importante nesse primeiro período foi o surgimento da imprensa negra, com jornais e revistas que começaram a circular nas principais capitais do Brasil, publicando textos que tratavam das questões que afetavam a população negra.

A partir da década de 1930, com o fim da República Velha, a diminuição do poder dos coronéis e dos Estados de Minas Gerais e de São Paulo, e a organização de uma vida mais urbana com o poder cada vez mais centralizado nas mãos do Presidente Getúlio Vargas, o movimento negro percebeu a necessidade de uma organização mais sólida, para garantir e efetivar os direitos do povo negro, a partir da luta pela diminuição do racismo. Assim, em 1931, no Estado de São Paulo, foi fundada a Frente Negra Brasileira - FNB.

A segunda fase desse movimento, que se estende de 1945 a 1964, período entre a ditadura do Estado Novo e a ditadura Militar, foi marcada pela retomada das ações em favor da população negra, que tinha retrocedido quase que totalmente devido à ditadura getulista. O recomeço aconteceu com a organização da União dos Homens de Cor - UAGACÊ, fundada em 1943, em Porto Alegre e que posteriormente se expandiu por vários estados do Brasil. A sua principal finalidade era elevar o nível econômico e intelectual das pessoas de cor em todo o Brasil. 
Outra organização importante foi o Teatro Experimental do Negro - TEN, fundado em 1944, no Rio de Janeiro, por Abdias do Nascimento. Este agrupamento social rapidamente extrapolou a condição de um grupo de teatro e passou a atuar com ações mais amplas, promovendo cursos de alfabetização, de corte e costura, publicação de jornais e fundação de um Museu. A partir desse momento o movimento negro já contava com organizações em praticamente todo o país, com destaque, inclusive, para o Conselho Nacional das Mulheres Negras.

Apesar de toda essa movimentação, a primeira lei contra a discriminação racial no Brasil somente foi aprovada pelo Congresso Nacional em 1951, resultado do projeto do deputado Afonso Arinos. Nesse momento, o Brasil foi marcado pela reorganização e ascensão dos setores conservadores na política, o que culminou com o golpe civil militar de 1964 , instaurando uma ditadura que duraria por cerca de 20 anos.

Durante esse período, verificou-se um intenso retrocesso político no Brasil, com a desarticulação e desmobilização dos movimentos sociais do país, inclusive as organizações do movimento negro, que só voltaram a se reestruturar a partir do final da década de 1970, com o início do processo de abertura política e o reaparecimento das organizações sociais e do movimento negro, com destaque para o ano de 1978, quando foi fundado o Movimento Negro Unificado MNU, conceituado a seguir.

O MNU se inspirou tanto na luta a favor dos direitos civis dos negros estadunidenses, onde se projetaram lideranças como Martin Luther King, Malcom X e organizações negras marxistas, como os Panteras Negras, quanto nos 
movimentos de libertação dos países africanos, sobretudo de língua portuguesa, como Guine Bissau, Moçambique e Angola. Uma forte inspiração nacional, que converteu em escola de formação política e ideológica de várias lideranças do MNU foi uma organização marxista, de orientação trotskista, convergência socialista (DIAS, 2012).

As principais bandeiras de luta do MNU estavam ligadas à defesa da desmistificação da democracia racial brasileira e da luta para organização política das populações negras do Brasil. O movimento negro transformou-se em movimento de massa. Além do MNU, outras organizações negras reaparecem e a imprensa negra voltou a publicar jornais em todo o Brasil.

A partir desse momento, o movimento negro passou a propor intervenções na educação brasileira, construindo propostas para uma pedagogia inter-racial e multicultural, na luta pela reavaliação do papel do negro na História do Brasil, assim como uma revisão na produção dos livros didáticos que permaneciam com a visão eurocêntrica.

Com a constituição cidadã de 1988, finalmente se garantiu a liberdade de culto e a laicidade do Estado brasileiro. O movimento negro, agora, com uma nova conceituação teórica, construída a partir da década de 1970 do século XX, estabelece relações diretas com os religiosos de matriz africana, muito em função de vários coletivos negros do Brasil passarem a ter nos seus quadros muitos religiosos de matriz africana. Assim sendo o combate ao racismo religioso na sociedade e nos espaços de educação formal tem tido uma preocupação cada vez maior do movimento negro organizado. 
A partir dos anos 2000 as propostas do movimento negro organizado conseguiram atingir o Estado brasileiro, que passou a promover ações afirmativas para a população negra, estabelecendo leis como, por exemplo, a lei de cotas raciais, sancionada no mês de agosto de 2012, garantindo a reserva de $50 \%$ das matrículas por curso e turno nas 59 universidades federais e 38 institutos federais de educação, ciência e tecnologia a alunos oriundos integralmente do ensino médio público, em cursos regulares ou da educação de jovens e adultos (BRASIL, 2012).

Entre os beneficiados por este sistema estão candidatos oriundos de comunidades indígenas e quilombolas. Foram criados órgãos governamentais federais, a exemplo da Secretaria de Políticas de Promoção de Igualdade Racial - SEPPIR, das secretarias estaduais e municipais de promoção da igualdade racial que interferiram diretamente na reorganização da educação, com proposta de caráter inclusivo dos negros em todos os níveis da educação, especialmente a partir do ano de 2003, conforme já mencionado anteriormente.

Porém, apesar de tanto esforço, tanta luta e dos avanços institucionais já citados, no que se refere às políticas públicas inclusivas ainda não se alcançou uma condição satisfatória para a população negra, particularmente no que se refere a uma educação que respeite a diversidade racial, que não discrimine nem pratique o racismo religioso, especialmente com as crianças e jovens de religiões de matriz africana.

Portanto, o que se percebe é que apesar de todo esse empenho do movimento negro para garantir melhores 
condições de vida para o seu povo e de ter conseguido muitas conquistas institucionais, ainda não se superou todos os anos de escravidão e dominação, tanto no aspecto político como no cultural. Os negros ainda são parte de uma sociedade que não admite a existência do racismo, mesmo percebendo que esta prática está estruturada no país onde a maioria das pessoas cultiva o sonho da democracia racial, conceito cunhado pelo sociólogo Gilberto Freire, no século passado, que construiu o modelo de sociedade miscigenada, em que as relações eram respeitadas e entendidas por todos os grupos raciais, apesar do fato de que o desejo do "embranquecimento" da população ainda exista até hoje.

As limitações relativas à efetivação das leis que consolidam as políticas públicas para a população negra tornam-se ainda maiores quando estas se referem ao estudo dos conceitos fundamentais das religiões de matriz africana na escola. A dificuldade para se discutir conteúdos sobre religiosidade africana esbarra em um conjunto de preconceitos, diretamente relacionados com a ideia de que essas crenças trazidas da África são demonizadas e existem apenas para praticar o mal contra as pessoas, o que leva à ampliação do racismo religioso com as crianças e jovens religiosos de matriz africana, que escondem no ambiente escolar todo seu pertencimento, evitando frequentar as aulas após o período de obrigação religiosa quando precisam utilizar elementos físicos identificadores da sua prática religiosa.

Este fenômeno, que faz com que essas crianças e jovens estabeleçam o silenciamento da sua religião na escola, leva-os muitas vezes a mentirem, apresentando-se como católicos ou evangélicos para não passarem pela 
humilhação cotidiana e, até mesmo, sofrerem agressões físicas, seja dentro da escola ou no caminho que fazem da sua casa até o local de estudo. Esse racismo religioso vem se tornando uma prática que provoca a diminuição da autoestima desses estudantes e influencia na queda do seu rendimento escolar; além de, algumas vezes, provocar o abandono da escola, ampliando o índice de evasão escolar.

\begin{abstract}
A questão é de grande relevância, dado o contexto de intolerância religiosa presente nas escolas públicas, afetando o bem-estar e a aprendizagem dos estudantes. De acordo com a Pesquisa Nacional de Saúde do Escolar 2015, publicada em 2016 pelo Instituto Brasileiro de Geografia e Estatística (IBGE), 4,2\% dos estudantes de 13 a 17 anos que disseram ter sido vítimas de humilhação na escola apontaram sua religião como motivo, é a quarta principal razão de provocações feitas pelos colegas, atrás apenas da aparência do corpo, da aparência do rosto e da cor/raça, e à frente de orientação sexual e região de origem (HIROMI; GOES, 2017, p. 33).
\end{abstract}

Portanto, entendo que a superação dessa questão abordada acima perpassa o entendimento da prática do racismo religioso como sendo mais uma faceta do racismo que predomina no cotidiano dos brasileiros até os dias de hoje. Desse modo, toda perseguição, agressão, destruição de espaços religiosos, violência contra crianças e jovens de terreiro na escola são práticas de um racismo religioso, não apenas uma intolerância, pois se observa que as ações contra os religiosos de matriz africana expressam um sentimento de ódio que pode ser explicado exatamente pelo fato de serem atacados não apenas os adeptos destas religiões, mas, também, pessoas afrodescendentes, que são maioria nestes espaços. 
Racismo religioso, portanto, é o conceito que se considera mais adequado para compreender a problemática desta obra, já descrita anteriormente. Para a superação do racismo religioso, entende-se que será necessária uma transformação cultural da sociedade, o que pressupõe informação e formação a partir de conceitos introduzidos pelos movimentos multiculturalistas, contemporaneamente estudados na academia, que defendem o multiculturalismo crítico, uma das bases teórico-conceituais que esta obra adota.

Para entender a relação entre o multiculturalismo e educação será preciso compreender as concepções teóricas desse movimento, que tem origem em meados do século XIX, nos Estados Unidos, difundindo-se pelo mundo ocidental como forma de combater os conflitos surgidos devido às questões políticas, econômicas e, particularmente, ao tratamento dado a questões culturais e étnico-raciais. Portanto, considera-se que a educação multiculturalista tem papel fundamental para efetivação das políticas públicas estabelecidas pelo Estado brasileiro a partir dos anos 2000. Entretanto, sua concretização somente é possível por meio da implantação de conceitos educacionais que tenham como base a construção de uma estratégia política de reconhecimento e representação da diversidade cultural e étnico-racial, não podendo ser concebidas desassociadas do contexto de luta dos grupos culturalmente oprimidos. Para Munanga (2010, p. 42),

O multiculturalismo não poderia reduzir-se a um pluralismo sem limites; deve ser definido, pelo contrário, como a busca de uma comunicação e de uma integração parcial entre os conjuntos culturais muito tempo separados como foram os homens e as mulheres, adultos e crianças proprietários e trabalhadores 
dependentes. A vida de uma sociedade cultural organiza-se em torno de um duplo movimento de emancipação e comunicação. Sem o reconhecimento da diversidade das culturas, a ideia de recomposição do mundo arrisca cair na armadilha de um novo universalismo. Mas sem essa busca de recomposição, a diversidade cultural só pode ser a guerra de culturas.

Assim, ao aplicar os conceitos do multiculturalismo à educação nacional estaremos construindo as condições para a real efetivação das políticas públicas educacionais, por meio da construção e transformação da base curricular do ensino básico brasileiro e da realização imediata de cursos de formação continuada para professores, coordenadores e gestores, com base nos princípios da diversidade cultural e religiosa, respeito às diferenças e combate à discriminação racial e de gênero. Além disso, a transformação a partir do conceito multiculturalistapressupõe a realização de uma revisão bibliográfica nos livros didáticos a fim de desfazer a concepção eurocêntrica da história e atribuir ao negro o protagonismo histórico, apresentando para as crianças e jovens afro-brasileiros a possibilidade de conhecerem sua História, sua ancestralidade, gerando, desse modo, aumento da sua autoestima.

Mais uma vez enfatiza-se a importância de abordar o racismo religioso como eixo de destaque nesta obra, já que o assunto perpassa todos os lugares da sociedade, inclusive a escola, bem como todas as pessoas independentemente de sexo, etnia, classe social, religião e opção política. Ao relacionar intolerância religiosa ao racismo pretende-se demonstrar que a discriminação, intolerância, desrespeito sofrido pelas crianças e jovens de religião de matriz africana nas escolas são reflexos da prática racista que está presente na sociedade brasileira, um espaço onde até hoje predomina 
o conceito de raça como uma ideologia, servindo à classe dominante que, em muitos casos, abala a identidade cultural de nosso país.

Com uma elite intelectual alienada em relação aos valores culturais e com uma classe dirigente aliada ao imperialismo econômico e à sua ideologia racista, seria ingênuo acreditar- se que o atual Sistema Educacional possa vir a organizar o ensino em desacordo com as classes que dominam a sociedade e de acordo com as características multirraciais que são a base da formação da população. Ou seja, se os formuladores do ensino no Brasil ainda são, em geral, pertencentes a uma elite intelectual eurocêntrica, é lógico que o ensino está centrado nos valores culturais europeus (TRINDADE, 1994, p. 13).

Finalmente, a principal questão abordada a partir deste relato histórico do movimento negro é evidenciar que os avanços institucionais alcançados nos últimos 17 anos, relativos à redução do racismo, não foram suficientes para a construção de uma sociedade que respeite e reconheça as diferenças raciais, religiosas dentre outras, porém foram muito importantes para a afirmação dos povos e grupos sociais que compõem a sociedade, pois Ihes conferiram instrumentos para sua afirmação. Possibilitaram, também, a ampliação da informação para a sociedade em geral sobre a realidade desses grupos e raças, bem como das dificuldades que encontram para se mostrarem plenamente.

Dessa forma, passa-se ao quarto capítulo desta obra, onde está relatada a trajetória de vida deste autor. Essa trajetória foi exatamente o que substanciou esta obra, ou seja, inspirou o problema da pesquisa, mencionado e fundamentado anteriormente. 

豆 



\section{4 \\ O eu no outro: reconhecendo-me negro}

A escrita de um livro sobre educação e relações étnico-raciais não seria possível se eu não tivesse passado por um processo de mudança de pensamento e ações a partir do momento em que entrei em contato com pessoas vinculadas ao movimento negro, que facultaram um conhecimento sobre questões raciais, interferindo muito na minha forma de pensar essas temas.

Durante toda minha vida, desde a infância até a fase adulta, fui formado com uma visão colonialista e eurocêntrica das relações raciais no Brasil. Nascido em uma família pobre, em Salvador, capital da Bahia, residia em um dos espaços mais elitizados da cidade, o bairro do Campo Grande, local privilegiado, no centro da cidade, onde moravam, por volta da década de 1970, as mais tradicionais famílias de Salvador.

Era ali, e em seu entorno, que se localizavam as melhores escolas privadas, os espaços de cultura, as melhores casas e edifícios. Porém, o bairro do Campo Grande, assim 
como outros bairros da cidade do Salvador, tinha outro lado que era periférico, pobre e carente, rodeado de dificuldades sociais. Exatamente neste ambiente, na Ladeira da Fonte, local de casas acanhadas e simples, ocupadas por uma população de classe baixa e muitos pretos e pardos, nasci e passei boa parte da minha vida. A Figura 4, a seguir, ilustra este contraste: os prédios estruturados, como o Teatro Castro Alves e o Colégio do Santíssimo Sacramento (Sacramentinas), e, em segundo plano, a ocupação irregular no vale e o casario ao longo da Ladeira da Fonte.

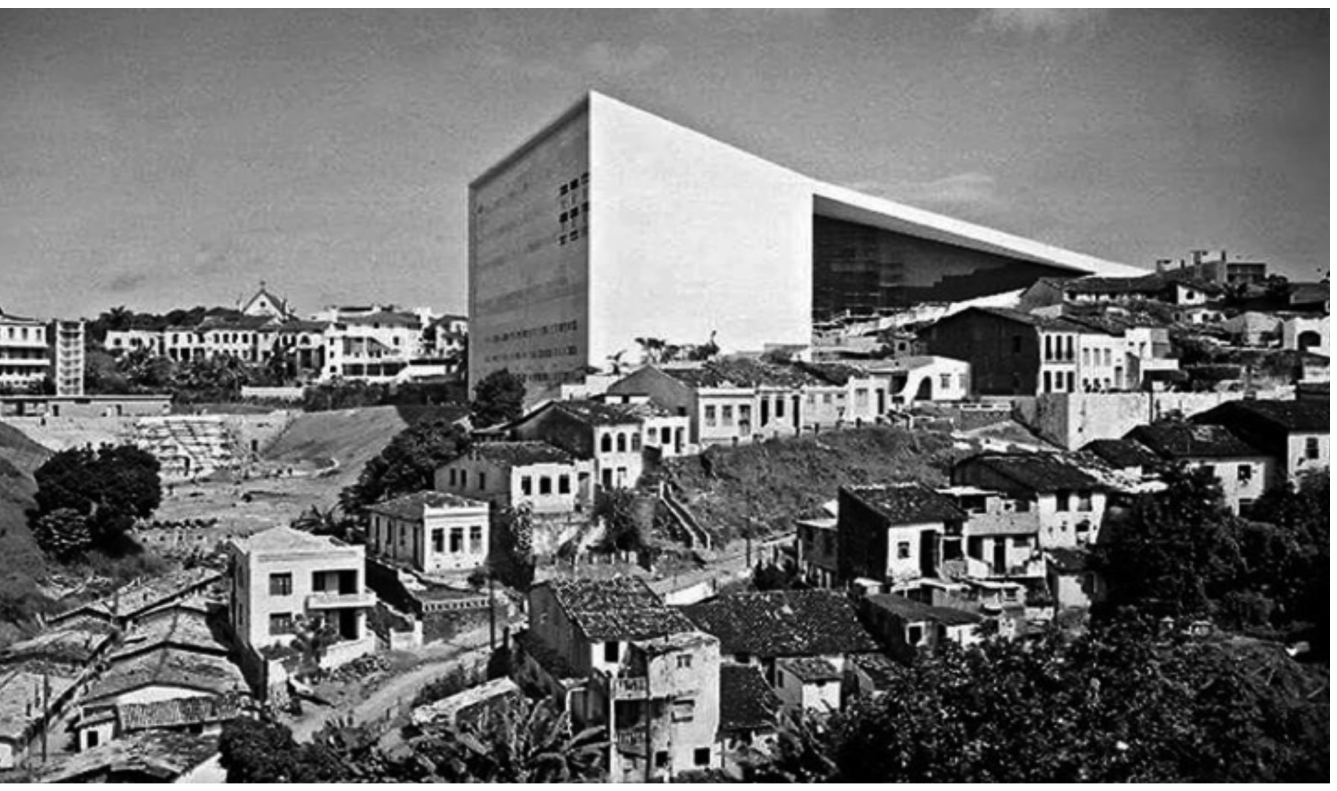

Figura 4

Fonte: Acervo fotográfico do Teatro Castro Alves.

Imagem da Ladeira

da Fonte. 
Ao final da Ladeira existia uma fonte de água limpa, que servia para abastecer as casas dos moradores e também para fornecer água para as senhoras, que ali residiam, ganharem a vida lavando roupa para as moradoras da parte alta do bairro.

Essa pequena descrição social e geográfica do espaço onde vivi a minha infância e juventude permite mostrar que nós, habitantes da parte pobre do bairro, mantínhamos uma relação de dependência e subalternidade com os moradores do lado elitizado, visto que era impossível e mesmo indesejável evitar o contato, pois não tínhamos como chegar em casa sem passar pela parte alta do Campo Grande e, naturalmente, conviver com esses seletos residentes que, por fim, proporcionavam trabalho e renda, apesar das nossas condições precárias.

Qual e como era esta relação? Sempre de subserviência, exploração e subalternidade, principalmente quando hoje percebo que, além da clara diferença social dos grupos, que conviviam teoricamente em perfeita harmonia, havia outra diferença que passava completamente despercebida por quase todos - a diferença racial: nós pardos e pretos e eles brancos. Apesar de tudo que nós passamos, muitas vezes servindo a eles, carregando as compras do mercado, lavando seus carros, cuidando dos seus jardins, não tinha percebido as questões de dominação racial que ali existiam, pois, a ideia de preconceito, discriminação racial, racismo ou coisa parecida ainda não estava presente na minha percepção de mundo.

Naquele momento, década de 1970, prevalecia a ideia de que o Brasil era um país completamente miscigenado 
onde predominava a democracia racial, fundamentada na teoria do cientista social pernambucano Gilberto Freire, escritor do livro Casa Grande e Senzala, que ameniza as diferenças raciais e mostra a harmonia existente entre todos os grupos étnicos brasileiros, como podemos observar abaixo.

Os pretos e pardos no Brasil não foram apenas companheiros dos meninos brancos nas aulas das casas-grandes e até nos colégios; houve também meninos brancos que aprenderam a ler com professores negros. A ler e a escrever e também a contar pelo sistema de tabuada cantada. Artur Orlando refere que seu professor de primeiras letras, em Pernambuco, foi um preto chamado Calisto. Calisto andava de cartola cinzenta, casaca preta e calças brancas. Trajo de gente lorde. De doutores e fidalgos coloniais com medo de hemorroidas ou já sofrendo da maldita doença que desde o século $\mathrm{XVI}$ parece ter perseguido os portugueses ricos ou letrados e seus descendentes no Brasil (FREIRE, 2003, p. 503).

O modo de vida de todos naquele espaço, envolvidos com as pessoas brancas de maior poder aquisitivo, não foi suficiente para eu perceber como a discriminação racial já estava presente durante toda nossa formação (minha e de meus cinco irmãos), pois erramos o reflexo da educação doméstica, seja orientada pelo pai ou pela mãe ou, até mesmo, pela avó.

Minha mãe e meu pai saíam todos os dias antes dos filhos acordarem para o trabalho, e minha educação ficava a cargo de Dona Celina, senhora forte e correta que exercia um papel de liderança em casa e também na comunidade; porém, uma pessoa que teve sua vida toda submetida ao domínio de um companheiro branco, rico e poderoso que, nos moldes patriarcais, determinava como ela deveria se 
comportar. Após o fim do relacionamento, ela veio para a casa de minha família e, quando eu nasci, ela já era a responsável pela nossa educação. Formada no contexto dominador, transferiu este modelo de educação para seus netos. Por exemplo, jamais deveríamos reclamar com ninguém e deveríamos aceitar tudo que fosse determinado pelas pessoas ricas e brancas que convivíamos. Esse modelo de educação doméstica, que não era tão diferente do que nos ensinavam na escola, só fortalecia a ideia de que a vida era maravilhosa e que as diferenças eram apenas a "vontade de Deus que tudo sabe e não deixa faltar nada para todos".

Realmente, em se tratando de coisas materiais, digo, refeições diárias, roupas novas ao final do ano para poder "passar o natal arrumado", livros e cadernos para frequentar a escola, nunca faltavam; faltava apenas entender por que erámos tão isolados pelos outros na hora das brincadeiras, ou por que, quando permitiam que participássemos destas, era sempre fazendo o papel menor, sempre o que perdia ou tomava pancada e não podia reagir, afinal, ali estavam meninos cujos pais ajudavam nossa família.

Assim foi nossa vida (minha e dos cinco irmãos) até a fase adulta, muitas vezes sendo reclamado por nossos pais que evitássemos ficar muito expostos ao sol, pois "corria o risco de ficar mais preto, o que não era bom". Hoje percebo que meus pais, da forma deles, já percebiam o racismo e tentavam de todas as formas esconder a nossa origem, talvez imaginando estarem nos protegendo e, indiretamente, ensinavam que não deveríamos dizer que éramos negros quando alguém perguntasse nossa cor. 
Crescemos com a ideia de que quanto mais clara fosse a cor da nossa pele, menos problemas sociais teríamos, apenas não era dito o porquê dessa necessidade. Eu sentia a discriminação, porém não sabia por que acontecia, pois, apesar de saber que a condição financeira de alguns era melhor que a nossa, isso nunca era usado como argumento para diminuir o outro, pelo contrário, lembro de muitas vezes ser ajudado financeiramente por todos. A questão com certeza era outra, mas eu só iria perceber muitos anos depois.

Logicamente que a ideia de embranquecimento da população brasileira, que sempre se constituiu de maioria negra, já que a base de toda economia colonial e imperial do Brasil se baseou no trabalho escravo por meio do tráfico de negros africanos, contribuiu muito para que eu acreditasse que a ideia de discriminação racial não existia; afinal de contas, eu sempre estava em busca de ser mais próximo do estereótipo branco. Com relação a esta teoria, o que diz Antônio Carlos Lopes Petan (2013, p. 37), na citação a seguir, contribui para esclarecer esse conceito:

Políticas de incentivo a imigração de alemães, italianos e espanhóis foram intensas no decorrer do século XIX e XX. Com o branqueamento da nação pretendia-se atingir uma higienização moral e cultural da sociedade brasileira. Clarear a população para progredir o país passou a ser um projeto de nação defendido no século XIX, mas que avançou pelo século XX. Projeto que envolvia eugenização e a higienização social enquanto políticas públicas.

Esses homens e mulheres foram de fundamental importância para a construção deste país, de acordo com a teoria eugenista, introduzida no Brasil no século XIX e 
permanecida no século XX, a qual pretendia eliminar negros e mestiços do país - alegando serem estes um atraso para o desenvolvimento, fazendo surgir apenas uma sociedade composta de brancos. Muito presente na nossa infância e adolescência, disfarçava todo racismo a que eu era submetido e não entendia.

Com a promulgação da Lei Eusébio de Queiroz, em 1850, que abolia o tráfico negreiro, causando a impressão de que a situação social dos negros melhoraria, a tendência a ter uma diminuição gradativa do número de cativos e mais negros libertos não se concretizou. Vale lembrar que, nesse mesmo ano, o governo do Imperador Pedro ll também sancionou a Lei de Terras no Brasil, estabelecendo o critério censitário para quem quisesse se tornar proprietário de terra no Império, e assim os negros que conseguissem sua liberdade por meio de uma Carta de Alforria ou até mesmo como resultado de lutas, fugas ou revoltas não teriam muita oportunidade de tornarem-se proprietários de terras, pois dificilmente teriam dinheiro para comprá-las e continuariam tendo que trabalhar em áreas dos grandes proprietários rurais.

Não bastasse essa atitude de garantir terras apenas para quem pudesse comprar, impedindo assim o negro ou a negra, até então escravizados, de serem donos de terra, restaria apenas a estas pessoas encontrarem um trabalho digno, que permitisse o sustento da sua família, o que também não aconteceu, visto que foi neste mesmo período que o país abriu suas portas para a entrada em grande quantidade dos imigrantes europeus, brancos, que fortaleceria ainda 
mais a tendência embranquecedora, tão presente naquele momento.

Na adolescência, durante o Ensino Médio, não foi tão diferente da fase infantil, descrita acima, talvez até um pouco pior no que se refere à discriminação racial. Isso porque, quando criança, frequentei escola pública, no próprio bairro, com colegas conhecidos, muitos da mesma rua que eu morava. Porém, ao seguir para o segundo grau, em um momento em que a situação financeira de meu pai e minha mãe tinham melhorado, e as escolas públicas estavam passando por um processo de precariedade enorme, eles fizeram um grande esforço para que eu estudasse em uma escola da rede privada, pois era o filho mais novo e aquele em que depositavam a esperança de, quem sabe, se tornar "doutor", o que não aconteceu.

Não era uma escola particular de alto padrão, porém tinha uma estrutura bem melhor do que as públicas e era frequentada por colegas de um poder aquisitivo maior, na sua maioria de pele branca; esse foi o maior problema a ser enfrentado. Não posso negar que, nos três anos em que frequentei esse espaço de educação, não tive momentos de felicidade e construção de boas relações e amizades; embora, durante toda essa etapa da vida, tenha passado por muitas situações desagradáveis, exclusivamente por conta da minha condição étnico-racial. Situações que, por quase toda minha vida, passaram despercebida, pois eu não tinha a noção de que tantas ações preconceituosas que passei na escola eram práticas claras de racismo.

Os constantes apelidos sempre me vinculando a coisas de cor preta; a exclusão sempre no primeiro momento 
da escolha dos alunos que iriam compor a equipe para um trabalho, mesmo todos sabendo que eu era um bom aluno e que podia contribuir para a realização da atividade; a dificuldade para me aproximar das garotas, que sempre preferiam paquerar os garotos de pele clara - jamais foram percebidos naquele momento. Às vezes, eu até refletia sobre o motivo que me levava a ser excluído das melhores atividades escolares.

Porém, apesar de não entender que tudo que eu passava era por conta da questão racial, inconscientemente tomava atitudes que podiam me fazer um jovem branco, diminuindo assim o desprezo dos colegas. Hoje, eu percebo o quanto era forte a ideologia do branqueamento na minha vida e como estava impregnada na minha mente, a ponto de construir uma sensação de inferioridade que me levava, muitas vezes, a não ter forças para participar de atividades artísticas, científicas, esportivas em igual condição com os outros e, frequentemente, me sentia incapaz para praticá-las, ou mesmo as abandonava. Sem perceber a ideologia do branqueamento, que já estava impregnada em mim, eu acreditava que só me tornando mais branco poderia me inserir na sociedade que vivia. A reflexão exposta pelas professoras Yari e Bento (2012, p. 6) é bem esclarecedora:

\footnotetext{
O branqueamento, todavia, não poderia deixar de ser entendido também como uma pressão cultural exercida pela hegemonia branca, sobretudo após a Abolição da Escravatura, para que o negro negasse a si mesmo, no seu corpo e na sua mente, como uma espécie de condição para se integrar (ser aceito e ter mobilidade social) na nova ordem social.
} 
A teoria do branqueamento ou embranquecimento foi uma das tantas temáticas construídas pela teoria eugenista na segunda metade do século XIX e na primeira do século XX, como já referido. Este pensamento defendia a ideia de que existia um padrão genético superior na raça humana, isto é, os brancos. As teses sustentavam a ideia de que o homem branco europeu tinha o padrão de melhor saúde, da maior beleza e da maior competência civilizacional em comparação às demais raças: amarela, vermelha e negra. No Brasil dos séculos XIX e XX, alguns intelectuais adotaram a teoria do embranquecimento com a intenção de justificar a superioridade da raça branca sobre os negros, principalmente no momento em que a população afrodescendente começava a conseguir, em maior número, a liberdade, o fim do cativeiro.

Para esses pensadores não era possível admitir o desenvolvimento da nação brasileira, povoada por tantos negros, a quem consideravam seres inferiores e responsáveis pelo atraso do Brasil. Era preciso, de acordo com eles, de alguma forma, tornar a sociedade brasileira cada vez mais branca, pois somente assim o Brasil alcançaria a condição de civilização, de nação desenvolvida.

Um dos principais intelectuais brasileiros neste momento foi o médico e antropólogo carioca João Baptista de Lacerda, que em 1911 participou do Congresso Universal das Raças, em Londres, evento que teve como finalidade reunir intelectuais do mundo inteiro para discutir o tema do racismo e da relação das raças com o progresso das civilizações. Este levou ao evento um artigo "Sur lés métis au Bresil" (Sobre os mestiços no Brasil), que defendia o processo da miscigenação como algo brasileiro esse fenômeno 
corresponde à sobreposição dos traços da raça branca sobre as outras, a negra e a indígena. Em um trecho do referido artigo, Lacerda (1911, s/ p) afirma que

\begin{abstract}
A população mista do Brasil deverá ter pois, no intervalo de um século, um aspecto bem diferente do atual. As correntes de imigração européia, aumentando a cada dia mais o elemento branco desta população, acabarão, depois de certo tempo, por sufocar os elementos nos quais poderia persistir ainda alguns traços do negro.
\end{abstract}

Com intenção de justificar ainda mais sua teoria embranquecedora explicada acima, outro fato chamou bastante atenção na participação do intelectual no congresso, a apresentação do famoso quadro do pintor espanhol Modesto Brocos: A Redenção de Cam, apresentado a seguir.

Esse quadro (Figura 5) foi concluído em 1895 e apresenta a imagem de uma família: à esquerda, uma senhora negra olhando para o céu em gesto de agradecimento e uma mulher mestiça segurando uma criança branca; à direita, um homem branco observando a esposa e o filho. A senhora negra, com as mãos para o alto, parece estar agradecendo ao senhor a possibilidade de sua filha, mulata, ter tido uma filha com um homem branco, o que fez dela uma criança bem mais clara que a mãe e que assim, de acordo com a teoria do embranquecimento, na próxima geração dessa família brasileira, os filhos seriam mais brancos e, em algumas gerações futuras, a raça negra, por eles considerada responsável pelo atraso brasileiro, não existiria mais.

A imagem do quadro de Brocos transmite categoricamente a tese que Lacerda (1911) defendia: o 


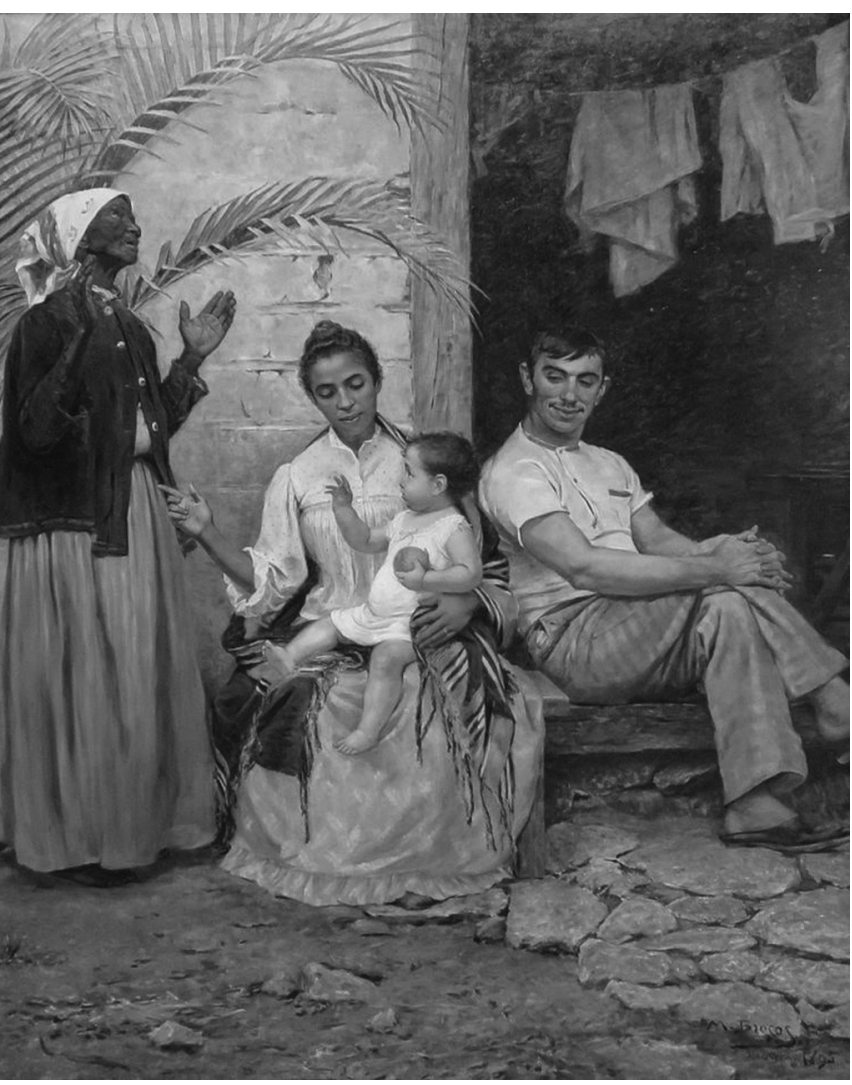

\section{Figura 5}

A Redenção de Cam.

Modesto Brocos,

1895.

Fonte: WIKIMEDIA, s.d 
embranquecimento por meio das gerações. Brocos (1895) propõe a diluição da cor negra na sucessão de descendentes e insere nessa sucessão a "redenção", a "absolvição" de uma "raça amaldiçoada", isto é, a descendência de Cam, filho de Noé, que, no livro do Gênesis, é amaldiçoado pelo pai. A história de Cam, a despeito de seu simbolismo bíblico, foi interpretada à revelia pelo racialismo do século XIX, no qual Brocos estava envolto. O "escurecimento" dos descendentes de Cam teria originado a raça negra africana, que poderia ser redimida por meio da mistura com a raça branca europeia.

Retomando o relato da minha vida, após essa conceituação necessária sobre a teoria do embranquecimento, passo a analisar o período em que eu ingressei na academia, apesar de todas as dificuldades e de muito sofrimento íntimo que passei durante toda minha trajetória, a qual me transformou em uma pessoa com muitos complexos, acreditando que não seria capaz de alcançar o Ensino Superior, que a conclusão do curso de segundo grau e um diploma de técnico era o limite. Porém, resolvi concorrer a uma vaga e fiquei surpreso por ter conseguido ingressar na concorrida Universidade Federal da Bahia (UFBA).

Aprovado no Curso de Licenciatura e Bacharelado em História, tive a impressão de que, a partir daquele momento, em que iria estudar a formação política, econômica, social e cultural do Brasil, poderia entender um pouco de toda aquela inquietação que não permitia que eu fosse um ser inteiro, pleno, confiante e pudesse caminhar olhando para frente, igual à outras pessoas. Minha autoestima estava sempre baixa por me sentir inferior aos outros. 
A trajetória da graduação não trouxe grandes novidades em relação aos estudos raciais, apesar de ter cursado História na Faculdade de Ciências Humanas da UFBA, na década de 1980, quando o Movimento Negro já tinha pelo menos uns dez anos de reorganização e o Movimento Negro Unificado (MNU) já defendia suas ideias por todo o país, apesar do regime de exceção que vivíamos. A universidade, nem mesmo o curso de História e muito menos os conteúdos estudados na Faculdade de Educação, não discutia as questões raciais, pois ainda tinha como referência os estudos fundamentados na perspectiva da democracia racial de Gilberto Freire (2003), explicitada anteriormente.

A base curricular da graduação em História discutia a questão africana durante apenas um semestre, ainda assim como disciplina optativa e com uma ementa que pouco estimulava o seu estudo, longe de alcançar o conteúdo trazido com o surgimento da Lei n. 10.639 (BRASIL, 2003), que determina o estudo da História da África e da Cultura Afro-brasileira nas escolas. Mas eu acredito que, mesmo sem essa determinação legal, um curso de História na UFBA deveria ser mais enfático neste tema. No entanto, a visão predominante era a do eurocentrismo colonizador que subalternizava o pensamento americano, como esclarece a professora Gomes (2008, p. 97), no texto a seguir:

Lamentavelmente, nas faculdades de Educação do país, não será difícil constatar a existência de uma estrutura curricular que sequer inclui o debate sobre as demandas dos movimentos sociais pela educação. As análises presentes nas diferentes disciplinas curriculares dos currículos de licenciatura em pedagogia ainda tendem a privilegiar os conteúdos, desconectados dos sujeitos, a 
política educacional sob o enfoque único do Estado e seus processos de regulação, e as metodologias de ensino sem conexão com os complexos processos por meio dos quais os sujeitos aprendem. O caráter conservador dos currículos acaba por expulsar qualquer discussão que pontue a diversidade cultural Etnicorracial na formação do educador (a). Assim, o estudo das questões indígena, racial e de gênero, as experiências e educação do campo, os estudos que focalizam a juventude, os ciclos de vida e os processos educacionais não escolares deixam de fazer parte da formação inicial de professores (as) ou ocupam um lugar secundário neste processo.

Observo que o estudo da civilização africana nas universidades, mesmo depois da promulgação da Lei (BRASIL, 2003), citada acima, apesar dos esforços de alguns educadores e principalmente do movimento negro, ainda está longe da implementação real dos conteúdos sugeridos pela legislação.

A vida de estudante de graduação não foi muito fácil, pois, quando estava cursando a faculdade, já estava casado e logo nasceu o meu primeiro filho, e foi preciso dividir o tempo de estudo com o trabalho e os cuidados de pai.

Em virtude de estudar em uma universidade federal, onde os horários de aulas eram distribuídos nos três turnos, o trabalho que foi possivel desempenhar foi o de professor em instituições de ensino da rede privada. Como já tinha sido aprovado nas principais disciplinas da licenciatura, não foi difícil a adaptação ao ambiente educacional. E, com muito pouco tempo nesta função, já estava lecionando em instituições conceituadas, tanto no aspecto intelectual quanto no financeiro. Assim, logo passei a conviver com alunos muito ricos e na sua maioria brancos. 
Porém, não só os alunos eram majoritariamente brancos, o corpo docente da instituição quase não tinha professores negros e eu fazia parte de uma exceção. Muitas vezes, na sala dos professores, eu era o único negro, junto com professores brancos, e, mais uma vez, eu não tinha a compreensão de que poderia se tratar de racismo, como já falei anteriormente.

Os conceitos de branquitude construídos na minha infância por minha mãe e minha avó tinham se internalizado e eu não conseguia me perceber, naquele momento, como um homem negro. Eu acreditava que, por não ser negro retinto, naquele ambiente passaria por branco. No entanto, um episódio ocorrido no ano de 1997, em uma das mais conceituadas instituições de ensino da cidade do Salvador, me fez passar por um grande constrangimento.

Este episódio ocorreu quando eu era vice-diretor da instituição de ensino e tinha como uma das minhas atribuições manter o controle disciplinar dos alunos, tendo sido necessário proibir que um deles se ausentasse das dependências da escola antes do término da aula. O aluno, desobedecendo essa orientação, pulou o muro da escola e saiu sem permissão e, como era uma atitude que ia de encontro ao regimento escolar, solicitei a um auxiliar que fosse ver onde ele estava e o reconduzisse à escola. Como era feito normalmente dessa forma, todos os alunos voltavam, se desculpavam e nada mais acontecia. Com esse aluno a situação foi diferente, pois, além de não voltar, ele foi desrespeitoso e ameaçador com o funcionário. Pouco tempo depois o estudante retornou à escola, acompanhado da sua mãe, que desejava saber o que tinha acontecido. 
Quando comecei a relatar o acontecido, a senhora não teve nenhum interesse em saber o que ocorreu, levantou-se da cadeira e deu início a uma série de agressões verbais e, por fim, uma agressão física, que atingiu o meu rosto. Porém, o que mais chamou a minha atenção foi que todas as palavras agressivas proferidas eram relacionadas à questão racial. Embora não me recorde literalmente das palavras, lembro exatamente o que foi dito, referindo-se a ter colocado seu filho para estudar em uma instituição conceituada como aquela, e ele ser proibido de sair por um negro, pobre, despreparado, inadequado para aquela função, em uma escola de pessoas de alta classe social, comunicando que solicitaria a minha demissão da empresa.

Logicamente, esse fato teve consequências. Eu fui à delegacia e registrei uma ocorrência de agressão e ofensa racial, e foi registrada e agendada uma audiência para tratar do assunto. Na presença do delegado, a agressora pediu desculpas e disse que estava arrependida do que fez, que estava vivendo um momento muito difícil.

Naquele momento, final da década de 1990, ainda não era um período em que as denúncias de racismo fossem tão evidenciadas, apesar da Constituição Cidadã de 1988 já ter definido o racismo como crime. Portanto, o fato foi amenizado e configurado como injúria racial, pelo delegado. Os movimentos sociais negros ainda não atuavam rigorosamente como hoje em dia, e por não ter a compreensão das questões étnico-raciais que tenho hoje, não dei prosseguimento à denúncia. Aparentemente, a situação foi resolvida, porém, emocionalmente e psicologicamente, aquele fato me 
marcou por muitos anos, motivando-me a procurar compreender as causas para o que ocorreu.

Não seria difícil dizer o que aconteceu ao final do ano, apesar de tudo ter sido resolvido na delegacia, o que a mãe falou no dia da agressão se concretizou e fui desligado da instituição. O aluno continuou estudando na escola e prevaleceu a lógica do dominador branco e rico sobre o subalterno preto e pobre.

Apesar dos fatos relatados acima, ainda demoraram cerca de dez anos para surgirem os meus primeiros questionamentos a respeito da questão racial e para que fosse possível entender como a condição étnico-racial no Brasil é realmente um fator fundamental no processo de discriminação e racismo. Passei boa parte da minha vida sofrendo discriminação racial e jamais tive a percepção do que acontecia, até esse episódio que ocorreu em 1997, que mencionei acima. Ou seja, eu não tinha nenhuma percepção da minha condição de negro, minha identidade negra não existia e por isso fui humilhado em muitas situações desde a infância, sem compreender os motivos.

Os anos passavam e aquela situação de 1997 era cada vez mais inquietante, às vezes parecia que o tempo se encarregaria de apagar aquelas lembranças que tanto me magoaram, porém, isso não acontecia; sempre que voltava o pensamento para o ocorrido, ou até mesmo passava perto do local onde aconteceu, a emoção era muito grande, e eu lembrava de tudo, com todos os detalhes, e ainda sem entender quase nada da sociedade racista que vivia. Pois, eu acreditava no conceito de democracia racial que relativizava as diferenças raciais e colocava a discriminação como alguma 
coisa inventada pelos negros, já que eu acreditava, também, que no Brasil não existia racismo e que somos uma sociedade miscigenada e diversificada convivendo harmoniosamente, conforme relata Theodoro (2013, p. 3) a seguir:

\footnotetext{
Mas o maior legado da obra de Gilberto Freyre foi a noção de Democracia Racial, largamente difundida pelo discurso oficial governamental a partir da segunda metade dos anos 1940, no período subsequente à Segunda Grande Guerra. O Brasil passa a se apresentar ao mundo - e a se representar - como lugar de convivência harmoniosa e salutar entre pessoas de todas as raças, credos e culturas. Um país sem embates raciais, plenamente miscigenado, verdadeiro exemplo de integração racial.
}

A teoria da democracia racial, em plena década de 1980, ainda era um conceito predominante no curso de história na UFBA e ainda usada como base da nossa formação. Porém, a partir de um encontro inesperado, meu olhar sobre as questões raciais começou a mudar. Esse episódio aconteceu no dia em que recebi a notícia que um ex-aluno, muito querido, tinha sido preso injustamente, acusado de um crime que não havia cometido.

Tratava-se de uma pessoa muito querida, comunicativa e cheia de amigos. Imediatamente, iniciaram uma grande mobilização para entender o que estava acontecendo e, como imaginávamos, nada foi provado; em pouco mais de uma semana, o aluno já estava de volta para casa. No dia do seu retorno, em uma comemoração surpresa, comecei a entender que tantas coisas que passei na vida era devido à minha condição racial e tinha noção dos motivos, digo isso porque foi nesse encontro que tive o prazer e a felicidade de 
ser apresentado ao irmão desse aluno, o professor Marcos Fábio Rezende Correia.

A princípio, percebi que eles eram pessoas diferentes, pois Marcos era uma pessoa fora do padrão que eu estava acostumado a conviver, mesmo morando em Salvador, tendo crescido em um bairro pobre e convivido em espaços de predominância negra. Ele era bem alto, vestido todo de branco, possuía um cabelo diferente, amarrado para o alto, com muitos colares pendurados no pescoço e mais falante do que todas as pessoas presentes. Ele não só falava, mas entrava, saía, gesticulava, atendia e falava no telefone celular, ao mesmo tempo em que conversava com as pessoas.

Aos poucos os amigos foram se ausentando e o ambiente ficando mais vazio e tranquilo e, como a casa de Marcos era próxima à minha, pois a essa altura eu já estava morando no bairro de Pituaçu, próximo do Imbuí e do bairro Boca do Rio, não tive tanta preocupação de sair e, finalmente, me aproximei de Marcos para conversar.

Comecei, então, a entender um pouco do porquê de tanta agitação naquele momento. Na verdade, era ele um dos responsáveis por ter resolvido tão rapidamente a situação do irmão. Aquele encontro, que só foi terminar por volta das 6 horas da manhã, foi o momento da minha vida que comecei a refletir sobre as questões étnico-raciais. Naquele momento, eu tinha conhecido uma das principais lideranças do movimento negro do Brasil, pois, Marcos Fábio Rezende era o Coordenador Nacional do Coletivo de Entidades Negras (CEN), uma organização não governamental, nascida em Salvador no ano de 2003, que é 
O Coletivo de Entidades Negras (CEN) é uma organização que atua pela garantia dos direitos civis das populações negras em seus múltiplos contextos, dimensões e prerrogativas de liberdade individual, de livre manifestação, pensamento e fé, direito de ir e vir e acesso à justiça e demais garantias constitucionais baseadas no princípio internacional da dignidade humana e nas prerrogativas da Conferência de Durban.

Criado em 20 de abril de 2003, o CEN não tem fins lucrativos e congrega entidades e pessoas alinhadas com sua missão, estando presente em 17 estados brasileiros. Suas ações têm, como público-alvo, indivíduos que vivem em situação de vulnerabilidade, excluídos do mercado de trabalho, com baixa escolaridade e sem perspectivas de inserção social, além de povos e comunidades tradicionais, mulheres, LGBTs e juventude negra (CEN, 2018, s.p.).

Além de Coordenador do CEN, Marcos era também Ogã da Casa de Oxumarê, um dos mais antigos e importantes terreiros de Candomblé de Salvador (Figura 6), que, juntamente com o CEN, desenvolvia várias ações voltadas para a defesa das questões étnico-raciais e de combate ao racismo religioso.

Esse encontro inesperado, como dito, começou a provocar uma grande mudança na forma de compreender as relações raciais no Brasil, pois aquele seria um dos muitos encontros que se repetiriam até os dias de hoje.

Naquelas horas de conversa, em que vimos o dia amanhecer, muita coisa foi tratada sempre com foco na história do negro no Brasil, afinal, era o encontro de dois historiadores, pois Marcos era também formado em História pela UFBA. A diferença é que, na década de 1990, quando ele estudou História, já havia outro cenário na universidade, e o estudo de História da África já era uma realidade. Provavelmente, 


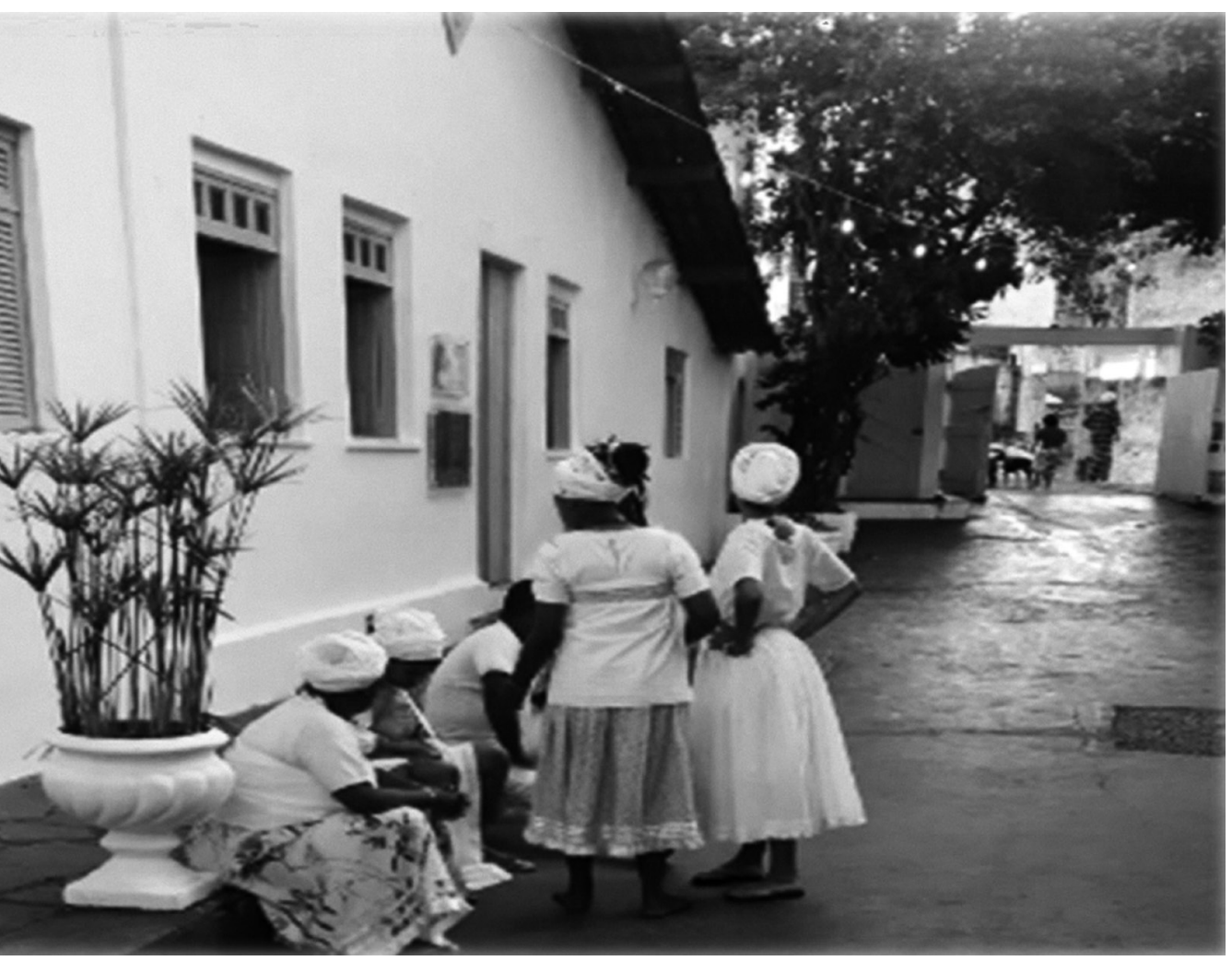

Figura 6

Fonte: dados do pesquisador.

Fachada da Casa de Oxumarê, 2018.

essa formação acadêmica, assim como o seu trabalho desenvolvido como coordenador da escola criativa do Bloco Afro Olodum, no Pelourinho, foi um fator fundamental para que ele tivesse tanto conhecimento e domínio da história da África e sua relação com as questões afro-brasileiras. Nesse sentido, cada conversa que tinha com ele era uma aula sobre essa temática. Estava cada dia mais envolvido e começando a perceber que as informações e as leituras que começava 
a fazer iam descortinando um passado racista e intolerante que vivi sem perceber, por muito tempo.

Uma semana após o primeiro encontro com Rezende, fui convidado a participar de uma reunião no Coletivo de Entidades Negras, que tinha como propósito elaborar um encontro de formação para jovens negros da periferia. Com o tempo, fui percebendo que estes encontros formativos eram parte permanente do CEN, era lá que se discutiam as questões do movimento negro, da sua importância para a história do povo negro brasileiro, e planejavam-se as ações futuras da entidade, além de fortalecer os laços de irmandade dos filiados ao Coletivo.

Com todas essas informações recebidas, fui motivado a aprofundar o estudo das questões teóricas que referendavam essa prática política, o qual envolve a temática étnico-racial. Assim, comecei a estudar os teóricos que dialogam sobre essas questões no Brasil e no mundo. Conheci o pensamento de Malcom X, o de Martin Luther King, aprendi sobre o Pan-africanismo, retomei alguns estudos sobre a história da África, sobre a teoria da democracia racial brasileira e dos intelectuais brasileiros que discutem e criticam esse pensamento, como, por exemplo, Munanga (2010), Lino (2017), Domingos (2007), Matos (2010), Barbosa (2013), Rezende (2013) e Candau (2011). Também revisitei as históricas lutas do movimento negro brasileiro e de como nossos ancestrais se organizaram e lutaram para garantir o direito dos negros e exigir políticas públicas de reparação para a população afro-brasileira, principalmente no que se refere à diminuição do racismo religioso na escola. 
Nesse sentido, passei a refletir sobre qual a contribuição imediata que poderia dar para apoiar aquela juventude negra que agora eu encontrava com frequência; ela despertava em mim uma vontade muito grande de crescimento e participação mais efetiva na sociedade, principalmente nas suas comunidades. Nesse momento da minha vida, além de continuar ministrando aulas na rede privada de ensino, na educação básica, era também diretor de um empreendimento educacional que se dedicava a preparar estudantes para a realização do Exame Nacional do Ensino Médio (ENEM) e de vestibulares. Tal empreendimento consistia no curso pré-vestibular Náutilus, que funcionava no bairro da Pituba e apresentava uma estrutura física que disponibilizava salas de aula em alguns turnos, constituindo uma oportunidade para colaborar com aquela juventude.

Em articulação com a Coordenação do CEN, fiz a proposta de iniciar uma turma preparatória para o ENEM, visando construir condições de acesso da juventude negra ao Ensino Superior.

Essa turma foi composta por jovens negros, moradores de periferias de Salvador, que comprovaram não ter condições de pagar mensalidade nos cursos privados da cidade. A proposta foi muito bem aceita pelos coordenadores e imediatamente começamos os trabalhos. Buscamos parceria com a Secretaria Municipal de Reparação da cidade de Salvador (SEMUR), cujos gestores também gostaram da ideia e juntos iniciamos as atividades. Não foi nada fácil, precisávamos de professores e coordenadores que fossem voluntários e organizamos toda a grade curricular, já que além das disciplinas básicas para a realização do ENEM, seria 
preciso inserir uma disciplina voltada para a discussão das questões afrodescendentes.

Em menos de uma semana de divulgação, foi preciso suspender as matrículas, pois a turma já tinha mais de 200 alunos. Os professores também foram chegando e identificando-se com o projeto; assim, o sucesso foi grande e, no final do ano, vários alunos conseguiram ingressar no Ensino Superior com a ajuda do cursinho.

Ser professor dessa turma, uma experiência que nunca tinha tido, foi de fundamental importância para me aproximar mais daqueles jovens, pobres e simples e, dessa maneira, fui conhecendo histórias dos seus cotidianos que me reportavam à minha infância pobre, de menino negro. As suas dores eram muito parecidas com as que eu tinha passado, que deixaram marcas profundas no meu corpo e na minha alma. Posso dizer que naquele ano aprendi muito mais do que ensinei. O sucesso maior veio no início do ano seguinte, após o resultado do ENEM. Muitos dos nossos meninos e meninas tinham conseguido aprovação e iam começar a realizar seu grande sonho: entrar na universidade e ter o diploma de um curso superior, o que talvez nunca fosse possível sem a iniciativa do CEN e a parceria com o curso Náutilus.

Após essa primeira ação proposta por mim e devido ao resultado superar as expectativas, fui convidado a assumir a Coordenação Estadual de Educação da entidade, cujo trabalho realizei por cerca de dois anos. Nesse período, organizamos novas formações para jovens e novos componentes do Coletivo, assim como para moradores de comunidades quilombolas. 
Com o passar do tempo, fui assumindo outras coordenações estaduais e nacional e a militância no CEN passou a fazer parte do meu cotidiano, por mais que o tempo fosse pequeno, devido às minhas atividades profissionais e familiares. Era, no entanto, impossível ficar distante de tanto aprendizado sobre as questões raciais, assim a convivência com os companheiros e as ações realizadas foram uma verdadeira escola. Ali, comecei a olhar a realidade social e racial do Brasil de uma forma jamais vista antes, constituindo-se em uma "viagem" ao meu passado, a cada discussão, debate, ação prática. Foi realmente um momento transformador do meu ser.

A amizade com o coordenador estadual do Coletivo de Entidades Negras, Marcos Rezende, ainda apresentou muitas surpresas, pois o CEN é uma organização que tem como uma de suas principais preocupações questões relacionadas às comunidades tradicionais de matriz africana, além disso, ele era, também, Ogã do Terreiro llê Axé Oxumarê, como já mencionado. Não demorou muito tempo para ele me fazer o convite para conhecer a instituição, o que de imediato aceitei, pois já tinha essa curiosidade, ou melhor, necessidade, uma vez que a convivência com pessoas do Candomblé era quase que diária, afinal de contas, quase todos os companheiros do CEN eram do Candomblé.

O meu primeiro contato com o Terreiro Oxumarê foi em uma quarta-feira, no início da noite, quando acontece a cerimônia religiosa dedicada ao Pai Xangô - Amalá de Xangố, cujo ritual consiste em oferecer para o orixá uma comida votiva, feita com quiabo cortado, raspa de cebola e azeite de dendê ou de oliva. Nessa cerimônia, os filhos e filhas 
de santo, juntamente com o Babalorixá e os convidados, reúnem-se na porta do quarto do Orixá, cantam, dançam, ouvem a palavra do Pai de Santo, que explica o que significa aquele ritual, pede por todos e deixa uma mensagem de esperança e fé. Após esse primeiro momento as pessoas fazem uma fila e os que já são praticantes da casa, um de cada vez, entram no quarto de Xangô, ajoelham-se, "batem a cabeça no chão" na frente do Santo, fazem seus pedidos e na saída recebem do Sacerdote uma colher do Amalá, que deve ser comido. Ao final, como em toda cerimônia de Candomblé, é servida a mesma comida aos convidados.

Nessa noite, o Amalá se estendeu até quase meia- noite e, como tinha sido convidado e meu anfitrião continuava na casa, também fiquei até a madrugada. Naquele primeiro dia de Candomblé, comecei a perceber o porquê de as pessoas de terreiro dizerem que, depois que passamos do portão de entrada daquele espaço sagrado, o tempo começa a ser contado de forma diferente; tem hora para entrar, porém a saída é por conta dos orixás.

Naquela noite, por exemplo, ter ficado até a madrugada foi muito interessante, pois tive contato mais estreito com a casa e os rituais. Por volta de 1 hora da madrugada, éramos apenas eu, Marcos, o Baba Atinsá7 (Pai Tinho) e o Babalorixá Babá Pecê, conversando sobre a cerimônia que tinha acontecido e sobre vários princípios do Candomblé. Fiquei surpreso de como participei da conversa com aquelas autoridades religiosas com certa desenvoltura, como se já fosse conhecedor da religião, mesmo sendo a primeira vez que tinha contato tão direto com um espaço religioso de matriz africana. Logo, passei a refletir sobre o que vivenciei
6. Comida feita com quiabo, cebola ralada, camarão, azeite de dendê ou doce, oferecida ao Orixá Xangô, servida em gamela normalmente às quartas-feiras.
7. Ogã responsável pelas funções de ebós e liturgia religiosa da casa, guardião dos quartos dos santos e das árvores sagradas. 
naquela noite, tudo que tinha acontecido comigo, desde a curiosidade inicial até a alegria imensa que tinha tomado meu corpo e minha alma.

A participação na conversa após o ritual não foi o que mais chamou minha atenção, mas sim a facilidade com que entendia o que se falava a respeito do Candomblé, pois, apesar de não ter nenhuma vivência prática da religião, possuía conhecimento teórico sobre o tema, uma vez que, nesse período, lecionava na Faculdade UNIBAHIA a disciplina História da Bahia, no curso de graduação em Turismo e Hotelaria, o qual previa em sua ementa o estudo das religiões africanas.

Na semana seguinte, mesmo sem a companhia de Marcos, voltei ao Terreiro para participar do Amalá de Xangô, pois, alguma força espiritual começou a me atrair cada vez mais para o Oxumarê, e a minha ida ao Terreiro foi ficando cada vez mais frequente. Em pouco tempo já estava bem entrosado e sendo tratado como alguém da casa; já era chamado para ajudar em algumas tarefas, principalmente aquelas que dependiam de transporte próprio, considerando que poucas pessoas tinham carro. Aos poucos, fui intercalando o pouco conhecimento teórico que tinha com as vivências práticas que podia presenciar.

O entrosamento com os Filhos de Santo, com os Ogãs, com as Ekedes ${ }^{8}$, as Egbomes ${ }^{9}$ e com o Babalorixá ${ }^{10}$ a cada dia ficava maior e, apesar de tão pouco tempo que eu frequentava o Terreiro, era como se já frequentasse aquele espaço há muito. Na verdade, a minha vivência religiosa por mais de 30 anos tinha sido com a Doutrina Espírita, parte da minha trajetória de vida que ainda não tinha relatado neste memorial. 
Desde muito cedo, por conta de tradição familiar, fui levado a frequentar o Centro Espírita, que funcionava na Federação Espírita do Estado da Bahia (FEEB), situada no Terreiro de Jesus, no centro da cidade do Salvador. Com menos de dez anos já estava participando das aulas de evangelização, aos domingos pela manhã, e com 15 anos comecei a frequentar e realizar atividades com o grupo de jovens, permanecendo lá por toda a adolescência. Ao deixar a juventude espírita, passei a trabalhar em outros Centros, tanto nas reuniões doutrinárias, inclusive como palestrante, quanto nas reuniões mediúnicas, aquelas onde os espíritos se manifestam através dos médiuns. No Candomblé, estes seres desencarnados são os Eguns ou Egum-gum, que em Nagô quer dizer Osso. Mas o seu significado é mais amplo, correspondendo também à "alma de pessoa morta". Esses seres ancestrais não são cultuados no culto de orixás e suas aparições só acontecem em cerimônias específicas, realizadas em espaços religiosos voltados apenas para cultuá-los, o que faz com que os Eguns, nos terreiros de orixás, sejam vistos como energias que não devem ser evocadas, sendo que a conversa sobre eles é bem reservada.

No entanto, a minha familiaridade com essas energias, devido ao atendimento a esses seres, que aprendi na convivência com o espiritismo, fez com que me aproximasse com maior facilidade das pessoas que tinham autoridade religiosa no terreiro. Eles gostavam de conversar comigo sobre o assunto e, assim, a cada dia que passava, a relação com a Casa de Oxumarê foi se estreitando.

No final do primeiro ano que estava frequentando a Casa de Oxumarê, fui convidado a participar de uma das
8. Feminino de Ogã, escolhida pelo orixá e não entra em transe.

9. Cargo do candomblé de quem já cumpriu o período de iniciação (Yaô), na feitura do santo, já tendo feito a obrigação religiosa de sete anos

10. Sacerdote das religiões afrobrasileiras, o mesmo que pai de santo, 0 que faz a consulta aos orixás através do jogo de búzios. 
11. Ritual das Águas de Oxalá que revela o nascimento do Orí

(cabeça) no aiyé (mundo material), rito que normalmente abre as atividades litúrgicas dos calendários das casas de candomblé.

12. Filha de santo do terreiro Axé Opo Afonjá.

13. Cabeça, mente, a inteligência.

14. Fruto sagrado e insubstituível dos rituais de candomblé e umbanda, ele tem diversas utilidades como por exemplo confirmar uma obrigação no candomblé.

15. Toda pessoa que entra para a religião do candomblé poderá ser iniciada ou não, vai depender da sua vontade e principalmente da vontade do orixá. Costuma-se dizer que todos que com frequência estão no terreiro participando das festas públicas são os abians.

16. Uma confraternização espiritual entre pessoas e os Orixás, um ritual de Osè inclui a limpeza do assentamento, 0 preparo e a oferenda dos alimentos de cada Orixá, cânticos, danças e rezas. mais significativas celebrações daquele llê, "As Águas de Oxalá"11, ritual que normalmente abre as atividades religiosas do ano. Na Casa de Oxumarê, essa cerimônia acontece na primeira sexta-feira do mês de janeiro, cujo ritual está descrito abaixo, por Maria das Graças de Santana Rofrigué - Orí Aperê ${ }^{12}$ - Mestre em Ciência da Religião pela Pontifícia Universidade Católica de São Paulo - PUC/SP e pedagoga pela Universidade Católica de Salvador-UCSAL, Omo orixá do Axé Opo Afonjá / Bahia.

\begin{abstract}
Esse ritual anual de purificação, renovação, pode ser considerado um "rito de passagem", o fim e o começo, um novo ciclo, reverencia a presença da água, fonte primordial da vida, que se apresenta em todos os rituais da Religião dos Orixás. O ritual começa na madrugada da sexta-feira com a confecção do baluwê (pequena cabana feita com bambus e de folhagens de coqueiros, pitombas, etc.) o ajubó do Oxalá mais velho será posicionado sobre uma enorme bacia. Outros assentamentos de Oxalá podem ficar ao lado acompanhando o velho Orixá, permanecerão até o $2^{\circ}$ domingo das águas quando então Oxalufan volta para sua casa. Começará então a procissão de ir no rio ou na fonte pegar água fresca, cada um com seu pote, jarro ou quartinha sobre seus Orís ${ }^{13}$, para depois levarem até a cabana de Oxalá e lá a lyalorixá ou Babalorixá estará esperando todos e em ordem hierárquica, receberá as quartinhas com água e lavará o Orí de cada um, colocando um Obi ${ }^{14}$ no Orí cobrindo-o com um ojá. Esse ritual é feito em todos que se encontrarem na casa, abians ${ }^{15}$, iniciados e visitantes, sem exceção, o Orí se renova. Retorna-se ao rio ou fonte mais algumas vezes dando seguimento ao osétb de Oxalá (RODRIGUÉ, 2001, p. 25).
\end{abstract}

A Figura 7, a seguir, mostra um dos momentos desse ritual, quando os participantes saem com suas quartinhas para buscarem a água de Oxalá. 
A minha primeira participação no ritual das Águas de Oxalá foi inesquecível, a energia que circulou no Terreiro naqueles três dias que fiquei por lá era de uma paz imensa e, além disso, eu nunca tinha permanecido no Terreiro por tanto tempo. Tudo era diferente do meu habitual, como deitar em muito silêncio, levantar com o dia clareando, comer comidas quase sem sal e basicamente brancas, enfim, rituais guiados pelo que são considerados como os desejos do Orixá homenageado - Oxalá, e que emanavam uma energia singular e confortante.

Aquele ato foi o que definitivamente determinou a minha escolha pelo Candomblé para seguir como religião. Compreendi que não tinha mais como abandonar tais ensinamentos e realmente queria me tornar um membro daquela casa. O ano novo começou e a minha presença no Terreiro de Oxumarê era cada vez mais frequente. Praticamente toda quarta-feira participava do Amalá de Xangô, visitava a casa sempre que podia para tomar um banho de folhas e estava em todas as festas públicas.

Aos poucos, comecei a participar das funções mais internas da Casa, não chegava como antes para as festas, apenas à noite quando era aberta para o público, mas já participava das celebrações aos Orixás, desde o dia anterior à festa. Assistia ao Orô ${ }^{17}$, ao Padê ${ }^{18}$ de Exu e permanecia no Terreiro até o início do Xirê ${ }^{19}$. Sentia-me feliz, pois, aos poucos, o Babalorixá e os Ogãs mais velhos começavam a atribuir algumas tarefas que eu deveria realizar durante a cerimônia pública, como tomar conta da porta de entrada do barracão, para organizar as pessoas, colocando os homens de um lado e as mulheres do outro; não permitir a entrada de
17. Parte do ritual do candomblé em que, por meio de cânticos e toques mais intensos, os Orixás são chamados a Terra.

18. Cerimônia expiatória do candomblé e de religiões de matriz africana, na qual se oferece a Exu, antes das cerimônias públicas ou privadas, alimentos, bebidas e animais na intenção de que tudo saia bem durante as celebrações

19. Uma palavra Yorubá que significa roda, ou dança utilizada para evocação dos Orixás conforme cada nação. 


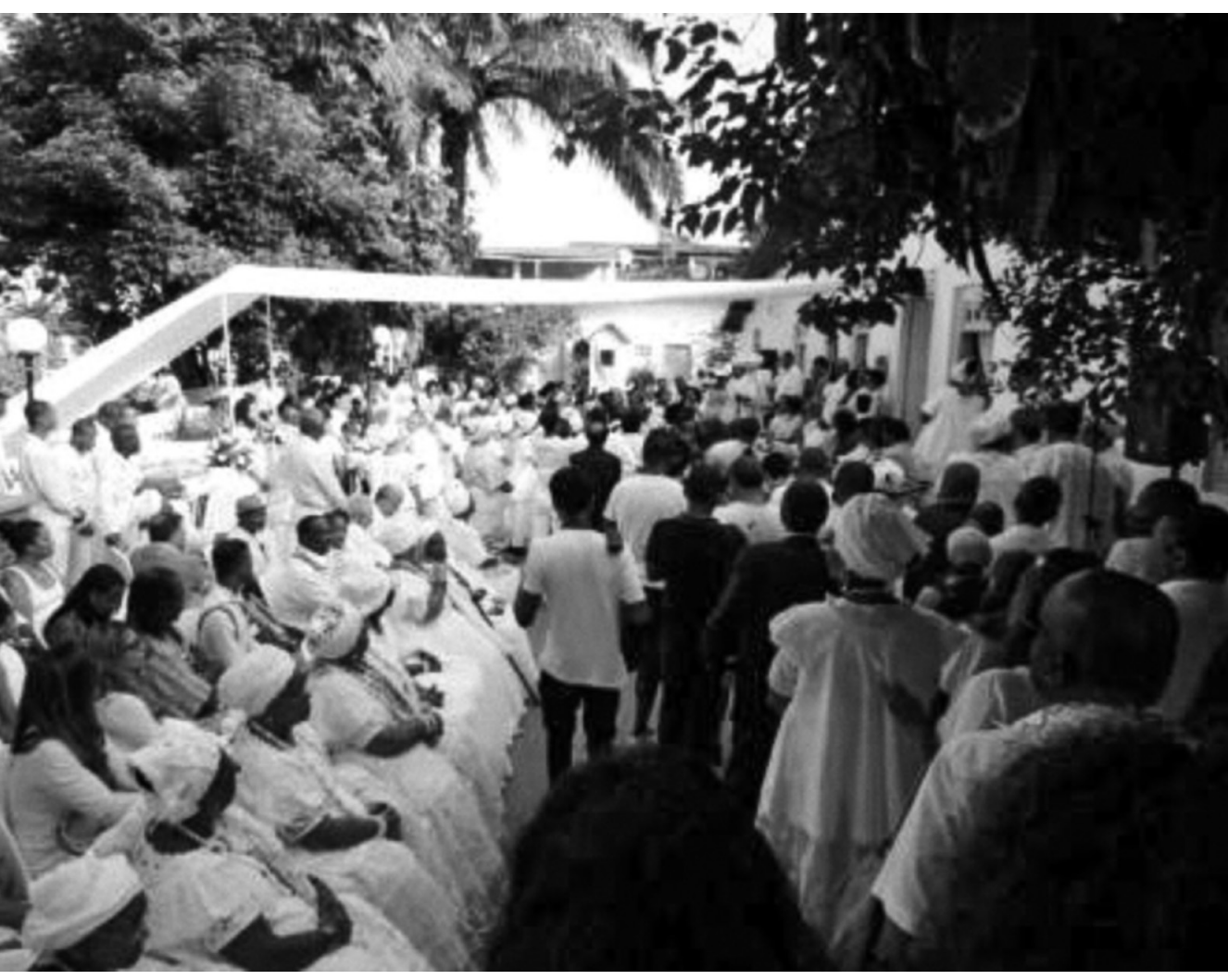

Figura 7

Águas de Oxalá. 
homens no salão vestidos de short ou bermuda; desautorizar o uso de máquina fotográfica para que nenhum visitante fotografasse ou filmasse o Xirê, pois a Casa de Oxumarê não permitia tais registros durante as festas.

Além dessas atividades realizadas no salão, eu já havia sido autorizado pelos mais velhos a receber os visitantes que chegavam para conhecer a festa, cuidar da arrumação da mesa onde seria servida a comida no final, organizar a fila para servir a comida, repor os pratos e lavá-los. Tudo isso parecia muito simples e até humilhante para uma pessoa com formação superior e com uma condição social melhor do que a maioria dos membros da Casa, no entanto, para mim, tudo que fazia e que passei nesses primeiros meses que frequentei o Terreiro era de uma importância muito grande. Foram essas atividades tão simples que desenvolvi que me fizeram entender a importância de uma das frases que se ouvia naquele espaço: depois que passamos daquele portão, todos somos iguais, não importa o título nem posição que tenhamos lá fora.

Eu era, então, um frequentador assíduo de todas as festas do Terreiro, o calendário anual já estava gravado em minha memória, também já tinha feito o meu primeiro jogo de búzios com o Babalorixá, que muito feliz me informou que Oxóssi era o dono do meu Ori - da minha cabeça, o que foi uma imensa alegria para mim também, pois quando militava no movimento espírita, a minha maior afinidade espiritual era com a ancestralidade indígena, ou seja, com os caboclos, que no Candomblé corresponde a uma qualidade de Oxóssi.

Porém, a maior alegria que até agora tive no Candomblé ainda estava por acontecer, e para minha felicidade 
não demorou muito. Ocorreu no terceiro sábado do mês de março do ano de 2008, cerca de um ano após a minha chegada ao Terreiro, na festa do Orixá Yemanjá. Como de costume, cheguei na sexta-feira à noite, dormi no quarto dos Ogãs e sábado, muito cedo, levantei e participei de todas as atividades religiosas preparatórias que antecedem à festa pública. À noite, eu estava pronto para iniciar o cumprimento das minhas funções na festa, já estava na porta do barracão controlando a entrada dos visitantes, quando a Ekede Cida, uma pessoa muito especial para mim no Oxumarê, pois foi ela quem primeiro me acolheu e passou as primeiras informações sobre o Terreiro quando lá cheguei, chamou-me, antes mesmo da festa começar, e disse: "meu irmão, Yemanjá quer falar com você agora". Eu confesso que não entendi do que se tratava, mas como já tinha aprendido que no terreiro não se questiona um chamado dos mais velhos, atendi imediatamente.

Ekede Cida me levou até o quarto das Yaô, onde os santos estavam sendo vestidos, e a Egbome Sandra, que já estava com seu orixá em terra, pegou-me pelas mãos e me deu um forte abraço, separou-se de mim e retornou ao quarto para terminar de se arrumar e ir para o salão. Voltei para a porta do barracão e continuei a desempenhar as minhas funções até aquele momento, que já descrevi anteriormente.

A festa continuou acontecendo. Naquela noite parecia mais linda. Uma energia maior e mais forte do que nas outras, mas como tudo programado, por volta da meia-noite, quando o salão já estava mais tranquilo, os Santos já tinham dançado e passado seu axé. Segui para o barracão de Omolu, 
onde seria servida a comida para os convidados. Como de costume, muita fartura e muita alegria para receber Ajeum ${ }^{20}$, além de muitas risadas e elogios ao sabor da comida.

Nesse momento, quando tudo parecia mais calmo, até os atabaques já tinham silenciado, eu já estava entregando os pratos na cozinha para serem lavados, senti uma mão firme segurando meu pulso, era Yemanjá. Mais uma vez, ela tinha deixado o salão e vindo até o meu encontro. Sem entender muito, deixei que ela me conduzisse até o barracão e, ao entrar, fui recebido com muitas palmas e muita gente desejando que tivesse muito Axé, até que os atabaques voltaram a tocar muito alto.

Então, Yemanjá me entregou ao Ogã André Luís de Xangô, que chamou o Ogã Marquinho de Xangô, Chico de Oxalá e o Babatinsá Luiz Augusto, que me sentaram em uma cadeira e me levantaram, passando pela porta do barracão, pelas portas dos quartos dos santos, pela cumeeira da casa, pelo altar dos atabaques, até me colocarem sentado junto à cadeira do Babalorixá, onde o Babatinsã Luís Augusto dirigiu-se a mim e fez a seguinte pergunta: "Meu irmão, você foi escolhido por Yemanjá para ser o membro desta comunidade, se tornar seu Pai e cuidar das coisas dela, você está sendo chamado a assumir responsabilidades neste terreiro com o cargo de Ogã, você aceita?". Ainda um pouco assustado, respondi que sim, os tambores dobraram tocando e uma fila se formou para me parabenizar. Naquele momento, passei a fazer parte oficialmente da Casa de Oxumarê, foi um dos momentos mais felizes que tive na vida.

Ao acordar, no domingo, fui chamado pela Egbome Lucinha de Omolu, que me segurou pelo braço 
21. Segunda pessoa na hierarquia do terreiro está logo abaixo do Babalorixá, também chamada de Mãe pequena da casa. carinhosamente, levou-me até a Yakekerê21 Sandra Bispo, que até então não sabia que a sua Yemanjá tinha escolhido mais um Ogã para cuidar dela quando estivesse em terra e, ao saber da novidade, a emoção tomou conta da Yakekerê, e Yemanjá imediatamente retornou a terra, para mais uma vez saudar seu Pai. Era muita emoção em muito pouco tempo.

Nesse mesmo domingo aconteceu a cerimônia de entrega do presente de Yemanjá na Praia do Rio Vermelho. Era a segunda parte das reverências ao Orixá que tinha sido iniciada no sábado e, pela primeira vez, eu podia estar bem pertinho do balaio que iria ser levado de barco até o meio do mar, era eu o mais novo escolhido pelo Orixá e era a sua festa, o que me fez sentir muita felicidade. Os irmãos de Santo me parabenizavam, e então senti a emoção de ser parte daquela família ancestral; entendi muito o que era ser do Candomblé, senti-me igual a todos e, finalmente, pude experimentar integralmente o pertencimento à raça negra pela primeira vez na vida.

Ali se encerrava um ciclo na minha trajetória de me descobrir um ser negro, mas muitas coisas ainda aconteceram para que eu pudesse realmente aceitar aquela condição. A relação da Casa de Oxumarê com o Coletivo de Entidades Negras foi ficando cada dia mais estreita, os encontros com os companheiros do Coletivo eram mais frequentes e sempre discutindo a temática relacionada à questão do racismo religioso, ampliando o meu interesse por este estudo. Em uma das primeiras reuniões, tive a oportunidade de conhecer a Yalorixá Mãe Jaciara Ribeiro de Oxum, coordenadora de religiões de matriz africana do CEN, cuja história era muito conhecida, pois ela vinha há muito tempo levantando a 
bandeira do combate ao racismo religioso e havia se tornado uma das principais vozes no Brasil contra essa prática.

Mãe Jaciara deu início a essa luta no ano 2000, logo após ter perdido a sua Mãe biológica, Mãe Gilda de Ogum, vítima de um infarto fulminante, depois de sofrer uma ação perpetrada por membros da Igreja Universal do Reino de Deus (IURD), que invadiram o seu Terreiro jogando pau e pedras e ofendendo verbal e fisicamente as pessoas que ali se encontravam, além de quebrarem objetos sagrados do llê, conforme descreve a seguir a pesquisadora Rego (2008, p. 1):

\begin{abstract}
A saga do Abassá de Ogum, hoje emplacada pela atual lyalorixá Jaciara Ribeiro dos Santos, filha consanguínea de Mãe Gilda, iniciou quando esta resolveu participar das manifestações públicas e populares pela reivindicação do impeachment do então presidente da república brasileira, Fernando Collor de Mello. [...] tudo muito divulgado na imprensa, com ampla cobertura na mídia televisiva, escrita e nas demais formas de comunicação. Entretanto, foi a forma de expressão da Mãe Gilda eleita pela IURD para atacar o povo do Candomblé na sua crença e manifestação prática da sua religiosidade. A revista Veja publicou matéria em 1992, em que aparecia uma foto de Mãe Gilda, trajada com roupas de sacerdotisa, tendo aos seus pés uma oferenda como forma de solicitar aos orixás que atendessem às súplicas daquele momento. A IURD publicou essa fotografia no jornal Folha Universal, em outubro de 1999, associada a uma agressiva e comprometedora reportagem sobre charlatanismo, sob o título: "Macumbeiros charlatões lesam o bolso e a vida dos clientes". A matéria afirmava estar crescendo no País um "mercado de enganação". Nesta reportagem, a foto da Mãe Gilda, aparece com uma tarja preta nos olhos. A publicação dessa foto marca o início de um doloroso, porém definidor processo de luta por justiça.
\end{abstract}


Até os dias de hoje, a Yalorixá Mãe Jaciara de Oxum continua lutando e desenvolvendo atividades de combate ao racismo religioso, além de ter comandado a pasta da Secretaria das Mulheres do Estado da Bahia, também foi coordenadora do Conselho de Desenvolvimento da Comunidade Negra da Bahia (CDCN). Mãe Jaciara consolidou toda sua luta quando, no ano de 2014, inaugurou no Largo do Abaeté, o busto de Mãe Gilda, transformando aquele espaço em local de luta, combate e encontro de membros de vários segmentos religiosos que desejam o fim do racismo religioso. O jornal Correio da Bahia ilustra esse fato na matéria intitulada "Yalorixá Mãe Gilda é homenageada com busto na Lagoa do Abaeté".

Quando os tambores tocaram sob o sol de 10 h de ontem, o olhar decidido e sério de Mãe Gilda, símbolo da luta contra a intolerância religiosa, ressurgiu em um busto em sua homenagem colocado às margens da Lagoa do Abaeté. A escultura, que até o momento da cerimônia estava coberta por um tecido branco, foi celebrada com grãos de milho branco, cânticos e mensagens que valorizavam o que a Yalorixá buscou: paz e respeito. Além da presença de membros de religiões de matriz africana, representantes de outras doutrinas religiosas compareceram ao local reafirmando a intenção de fazer da obra um ponto de referência ecumênica (CORREIO DA BAHIA, 2014).

A matéria enfatizava ainda que os representantes de diversas doutrinas religiosas, presentes na inauguração, reafirmaram a intenção de fazer da obra um ponto de referência ecumênica. A seguir, a Figura 8 mostra a imagem de Mãe Jaciara de Oxum junto ao busto de sua Mãe Gilda. 
Após o falecimento de Mãe Gilda de Ogum, sua filha Jaciara Ribeiro moveu uma ação judicial contra a IURD por danos morais e uso indevido da imagem. Cinco anos após o início do processo judicial, a justiça condenou a IURD, obrigando-a a publicar a sentença proferida pela justiça na capa

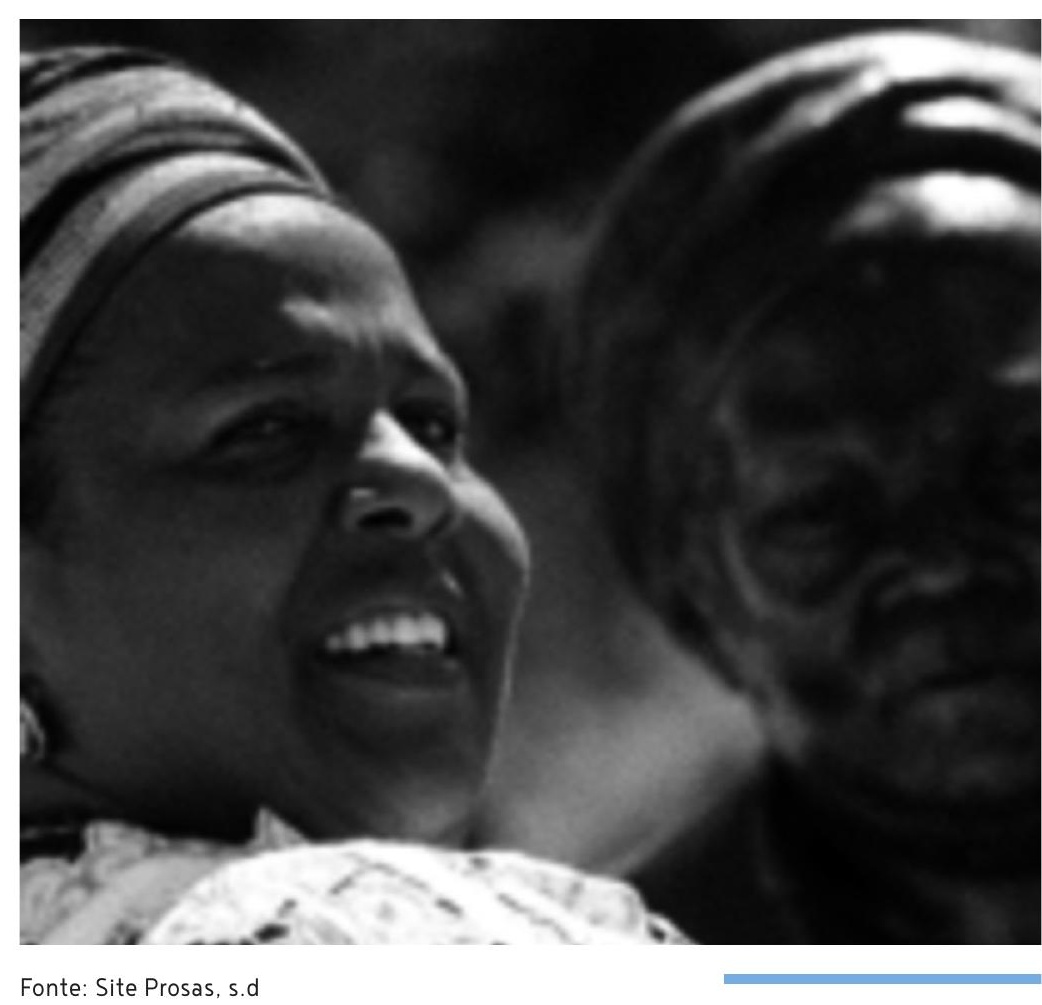

Figura 8

Mãe Jaciara de

Oxum junto ao busto

de sua mãe Gilda 
do mesmo veículo de comunicação que publicou a matéria, pagar R\$1.372.000, correspondentemente a R\$1 por cada exemplar da revista reajustado pelo INPC, desde 1999, além de determinar que o Ministério Público abrisse processo criminal contra a IURD.

A IURD apelou da decisão para o Tribunal da Bahia. Após cinco anos de processo e de muita pressão do povo de Santo, inclusive por meio de manifestações nas ruas da cidade e na porta do Tribunal, a nova decisão ratificava a primeira instância, apenas reduzindo o pagamento da indenização para R\$960.000. Insatisfeita com a decisão da instância estadual, a Igreja Universal recorreu ao STF, que em julgamento ratificou a decisão local por unanimidade, porém, fazendo uma imensa redução no valor indenizatório, que ficou em $\mathrm{R} \$ 145.250,00$. Claro que financeiramente este valor não representaria quase nada para os cofres da igreja nem repararia a perda que sofreu Mãe Jaciara e toda a comunidade religiosa do Terreiro Abassá de Ogum, porém essa não deixou de ser uma importante vitória política na luta contra todo ato de racismo religioso no Brasil.

A partir desse fato, esta temática tomou outra proporção e sua discussão e as ações do movimento negro e das comunidades tradicionais tornaram-se frequentes, fazendo com que a luta se ampliasse por vários segmentos da sociedade, inclusive nos meios acadêmicos. A luta de Mãe Jaciara ganhou expressão em âmbito nacional, tendo a Presidência da República, no ano de 2007, sancionado a lei que estabelecia o dia 21 de janeiro, dia do falecimento de Mãe Gilda de Ogum, Yalorixá do Terreiro Abassá de Ogum, como o dia nacional de combate à intolerância religiosa. 
Minha participação em boa parte dessa luta, principalmente após a filiação no Coletivo de Entidades Negras e convivência frequente com Mãe Jaciara, inclusive no Abassá de Ogum, ampliou o meu interesse pelo tema do racismo religioso. Essa inquietação sempre foi mais forte quando se tratava das crianças e jovens, que eram do terreiro e sempre relatavam as suas dificuldades e as perseguições que sofriam no ambiente escolar, por serem de Candomblé, todas as vezes que se apresentavam com algum elemento ou falavam alguma coisa que fosse relacionada à religiosidade africana. Eram, muitas vezes, isolados e tratados como "filhos do diabo".

Foi conversando com várias crianças e jovens, Filhos de Santo de Mãe Jaciara, que percebi que, enquanto educador, era preciso fazer alguma coisa para diminuir o sofrimento daquelas pessoas. Muita coisa ainda iria acontecer, muitas lutas ainda seriam travadas por mim, pela Casa de Oxumarê e pelo Coletivo de Entidades Negras, até eu entender que um dos caminhos possíveis a seguir para melhorar e contribuir para acabar com essa situação seria produzir materiais didáticos que pudessem ser usados nas escolas pelos alunos e seus professores, motivo que me levou a iniciar a produção de um livro, em forma de cartilha, com esta temática durante o curso de mestrado.

Durante os anos de 2008 a 2014, tive a oportunidade de, juntamente com o CEN e outros setores do movimento negro, participar de várias outras lutas, além das relatadas acima, em defesa de Terreiros de Candomblé contra ações de racismo religioso sofridas por essas instituições. 
A primeira esteve relacionada a um dos mais duros golpes já sofridos por uma casa de Candomblé na Bahia, na atualidade. Trata-se de uma ação promovida pela Superintendência de Controle e Ordenamento do Uso do Solo da Cidade do Salvador (SUCOM), órgão da Prefeitura Municipal de Salvador, que, em uma manhã de quarta-feira, chegou com seus prepostos e aparato policial militar, com uma suposta ordem de despejo e reintegração de posse da área, onde há mais de 29 anos estava localizado o Terreiro llê Axé Oyá Onipó Neto, da sacerdotisa Mãe Rosa de Oyá. Mãe Rosa, antes de esboçar qualquer reação, ou seja, antes de ter direito de fazer alguma explicação, mesmo tendo em suas mãos documentos que comprovavam a propriedade do terreno, viu sua casa quase toda derrubada, em menos de 30 minutos, sem ter como impedir.

Imediatamente, a notícia se tornou pública e várias autoridades religiosas da Bahia, líderes de movimentos negros, entre eles o CEN, assumiram a defesa por meio da divulgação do fato nos órgãos de imprensa, que, no mesmo instante produziram reportagens no local. As ações em defesa promovidas pelo Povo de Santo e por movimentos sociais provocaram grande repercussão, fazendo com que a demolição fosse suspensa de imediato; a discussão agora seria na esfera judicial e por meio da pressão diária sobre o prefeito de Salvador. Passeatas, audiência, vigílias, intervenção de órgãos de direitos humanos do Brasil e do mundo fizeram o prefeito voltar atrás na sua decisão, determinando a reconstrução de toda a área destruída, além de exonerar a gestora da SUCOM, responsável pelo ato, bem como procedeu ao pagamento de indenização para a Mãe de Santo. As fotos (Figuras 9, 10 e 11) e os relatos da época mostram, 
com mais clareza, os trágicos fatos sofridos por toda aquela comunidade religiosa.

Conforme podemos observar nas figuras 9, 10 e 11 e na citação a seguir, a destruição do terreiro llê Axé Onipó Neto foi quase que total, porém, mesmo vindo a público pedir desculpas, a responsável pela ordem da demolição foi exonerada do cargo pelo prefeito de Salvador.

O terreiro Oyá Onipó Neto, localizado há mais de 29 anos na Avenida Jorge Amado, em Salvador, foi parcialmente demolido em 27 de fevereiro, o que provocou polêmica e uma série de manifestações contra a intolerância religiosa. A responsável por autorizar a demolição, Kátia Carmelo, foi exonerada do cargo de chefia da Superintendência de Controle do Uso do Solo do Município (Sucom) e o prédio está sendo reconstruído. De acordo com a prefeitura, a demolição foi ordenada por um suposto problema na escritura. Em nota, Kátia Carmelo disse que percebeu ter havido excesso na ação dos prepostos da Sucom, pediu desculpas alguns dias após a derrubada do prédio, o prefeito de Salvador, João Henrique Carneiro, pediu desculpas pelo ocorrido, em público, e anunciou que o templo seria reconstruído. Segundo a mãe-de-santo Rosalice Santos do Amor Divino, de 50 anos, uma construtora, cujo nome é mantido em sigilo, assumiu a obra (ARAÚJO, 2008, s.p.).

O segundo episódio que presenciei e participei ativamente, relativo ao racismo religioso, aconteceu no ano de 2012 após a ação judicial que determinou a devolução do terreno localizado no bairro de Brotas, em Salvador, onde há mais de 50 anos estava localizado o Terreiro llê Axé Airá Izô, da Sacerdotisa Mãe Angélica de Ogum.

De acordo com informações de Mãe Angélica, o Terreiro estava localizado em um terreno cedido à Yalorixá pelo 


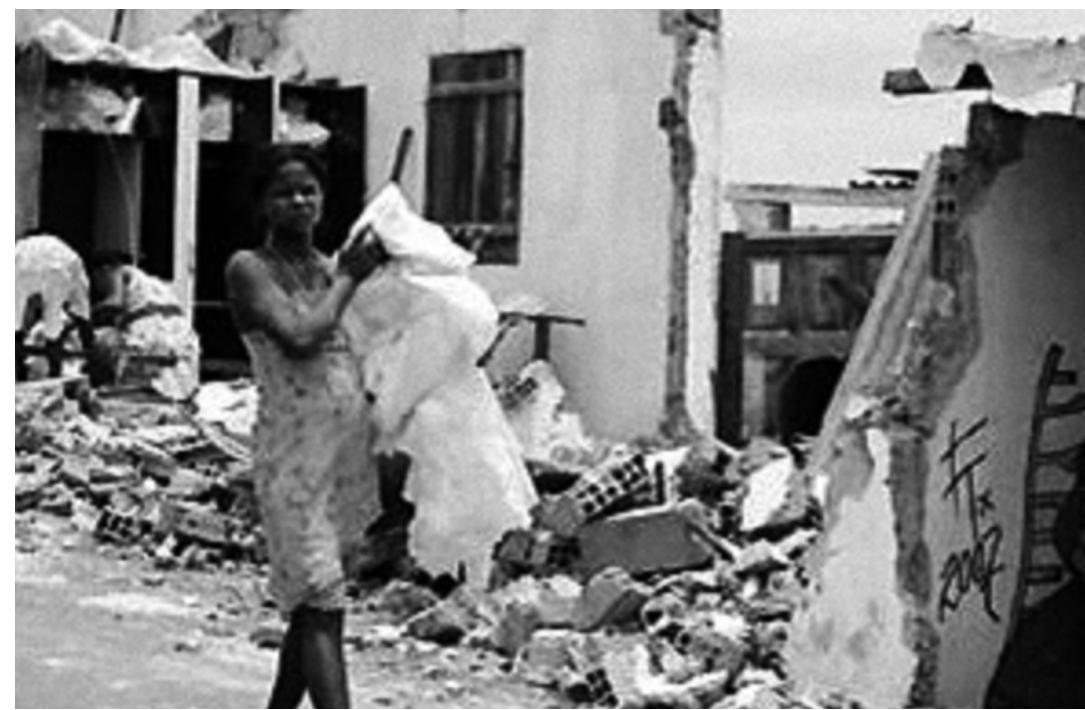

Fonte: Revista Fórum, 2008

Figura 11

Imagem do Terreiro llê Axé Onipó Neto. demolido. 
proprietário, há cerca de 50 anos, logo após ter alcançado a cura da sua filha, que, conforme os médicos, não sobreviveria por muito tempo. A criança, que tinha na época cerca de 4 anos de idade, foi recolhida no Terreiro por um tempo e saiu sem nenhum problema de saúde. Em gratidão a dona Angélica, Mãe de Santo que acolheu e cuidou da sua filha, o dono da terra presenteou a Yalorixá com toda a área.

Muitos anos depois, a criança que havia sido cuidada e curada por dona Angélica, que era sua afilhada, entrou na justiça reivindicando a posse do terreno. Na época da doação, a área em questão era periférica, distante do centro urbano e de pouco valor financeiro; porém, no momento em que foi ajuizada a ação, o terreno onde o Terreiro estava localizado pertencia a um dos locais bem valorizados de Salvador. Por vários anos a disputa pelo terreno foi travada na justiça; porém, nesse momento a Mãe Angélica não esteve sozinha nessa disputa, pois uma mobilização dos movimentos sociais que lutam contra o racismo religioso esteve presente por meio de manifestações, passeatas, acompanhamento das audiências e pressão sobre o governo estadual que, finalmente, decidiu desapropriar o terreno e garantir a permanência do Terreiro naquele espaço.

A atitude do governador foi resultado de uma ação pública mobilizada por autoridades religiosas da Bahia e do Coletivo de Entidades Negras durante uma solenidade de lançamento da Sétima Mostra de Direitos Humanos, com a participação da ministra Maria do Rosário e do governador Jaques Wagner e outras autoridades. Na oportunidade, a ministra declarou: "Direitos Humanos se constrói assim, nas ruas" (AMORIM, 2012, s.p.). Segue trecho da reportagem 
intitulada "O Axé quebra protocolo para proteger tradições afrodescendentes":

[...] Governador Jacques Wagner se sensibiliza com a situação
do llê Axé Ayrá Izô ameaçado de demolição e anuncia desapro-
priação do terreno onde funciona terreiro para proteção das tra-
dições afrodescendentes. Na noite da última Segunda-Feira, 10
de dezembro, o Pelourinho voltou a ser palco de momentos de
grande relevância para a história e a cultura afrodescendente. Era
para ser apenas a abertura oficial da 7 a Mostra de Direitos Huma-
nos, mas representantes do llê Axé Ayrá Izô e outras autoridades
religiosas, vestindo o branco de Oxalá, quebraram o protocolo e
celebraram a terceira noite da Festa para lansã no palco montado
para a solenidade. Em meio às atividades pelo Dia Internacio-
nal dos Direitos Humanos, a manifestação estava chamando a
atenção das autoridades, personalidades e demais presentes para
o risco iminente de demolição do Terreiro com mais de 50 anos
de atividades, por força de uma ação de reintegração de posse.
(AMORIM, 2012, s/p).

O resultado vitorioso desse movimento foi de significativa relevância, não só por reparar uma injustiça contra - Terreiro em questão, a sua Yalorixá e aos demais participantes da Casa, mas também por demonstrar a importância da organização social na conquista de direitos em geral e, particularmente, no avanço em relação à igualdade racial e respeito às diferentes religiões; no caso, o Candomblé. A Figura 12, a seguir, ilustra a participação do Povo de Santo e dos movimentos sociais na defesa dos seus direitos.

Na imagem abaixo (Figura 12), os adeptos do Candomblé vestem a cor branca, cor de Oxalá, o orixá que simboliza a paz. Hoje, o Terreiro llê Axé Airá Izô segue suas funções em paz, com seu espaço assegurado, desenvolvendo 
suas atividades religiosas e os trabalhos sociais para a comunidade.

A terceira atividade que desenvolvi em conjunto com o CEN foi bem mais prazerosa que as duas anteriores, pois não foi luta para reconstrução de Terreiro nem disputa na justiça para garantir a posse de terreno. Essa ação foi resultado de um edital do governo do estado da Bahia, vencido pelo

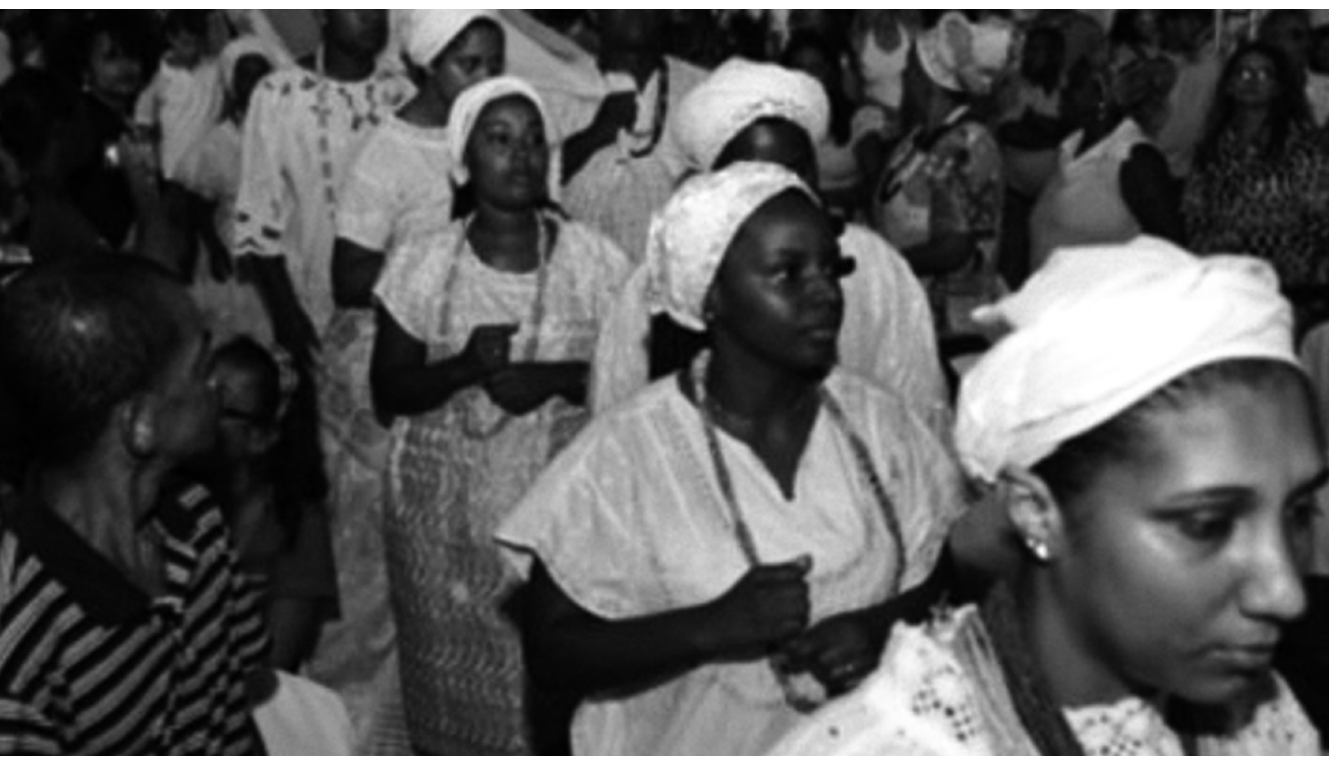

Figura 12

Imagem do ato do

Povo de Santo na

abertura oficial da $7^{a}$

Mostra de Direitos

Humanos. 
Coletivo de Entidades Negras em parceria com a TV Pelourinho, que consistiu na produção de um livro que retrata a história de cerca de 300 mulheres de Axé de Salvador, de outros municípios da Região Metropolitana de Salvador e da região do Recôncavo baiano.

Após as primeiras reuniões para discutir a elaboração do livro, decidimos que usaríamos a metodologia de pesquisa direta com as mulheres selecionadas, e para isso contratamos os pesquisadores, fotógrafos, maquiadores, motoristas e os tabuladores dos dados da pesquisa e produtores do texto final. Para minha alegria, eu fui escolhido como coordenador geral da pesquisa, o que permitiu que acompanhasse todos os grupos e fizesse contato com a maioria das senhoras entrevistadas. Nossa primeira preocupação foi com o critério para a escolha das Mulheres de Axé que seriam selecionadas para participar do projeto editorial e, depois de muitas reuniões e discussões, optamos pelos critérios descritos na citação a seguir, que compõe a apresentação do livro.

No que concerne aos critérios utilizados para captação das imagens e dos históricos de vida, a escolha destas Mulheres de Axé se deu pela representatividade social das mesmas e pela construção familiar de empoderamento matriarcal dentro dos seus respectivos Terreiros de Candomblé e seus reflexos dentro do contexto baiano. Nesse sentido, aqui fizemos a escolha pautada em critérios de tradição e transmissão do Axé ao longo dos anos, no empreendedorismo desempenhado por essas mulheres e as suas respectivas comunidades, nas ações sociais desenvolvidas em prol das (os) mais necessitados (as), na integração social junto as comunidades do seu entorno e, finalmente, no empoderamento feminino esboçado na condução do Axé (CIRNE; SILVA, 2013, p. 48). 
Selecionadas as mulheres a serem entrevistadas, iniciamos a pesquisa direta. A cada encontro conhecíamos uma história de vida emocionante, e naquele momento tive oportunidade de entender a dor daquelas senhoras que relatavam suas histórias de vida, seus sofrimentos, toda discriminação, intolerância e racismo religioso que passaram. Percebia que muitas, em algum momento, misturavam-se com minha história de sofrimento, discriminação e racismo que vivenciei sem nem entender o que acontecia. Esse trabalho desenvolvido para a construção do livro Mulheres de Axé (Figura 13) foi decisivo para eu assumir definitivamente a minha condição de negro e reforçar a importância de me engajar, cada vez mais, na luta para impedir que outras crianças sofressem tudo que sofri na minha história de vida.

A partir do ano de 2014, minha vida teve uma radical mudança, pois se iniciava uma nova fase de luta e aprendizado sobre as questões raciais, fora da minha terra natal, Salvador, quando problemas financeiros fizeram com que eu fosse residir no interior da Bahia, na cidade de Vitória da Conquista. Esse município situa-se no Território de Identidade do Sudoeste da Bahia, um ambiente muito diferente da capital, começando pela temperatura muito fria, chegando, em alguns períodos do ano, a medir 7 graus. A princípio, as dificuldades foram muitas, pois, além da frieza do clima, as pessoas também eram frias, difíceis e muito preconceituosas, principalmente com os negros, que vivem, na sua maioria, distantes do centro, em bairros localizados na periferia ou na zona rural, e muitas dessas comunidades são originárias de remanescentes de quilombos. 


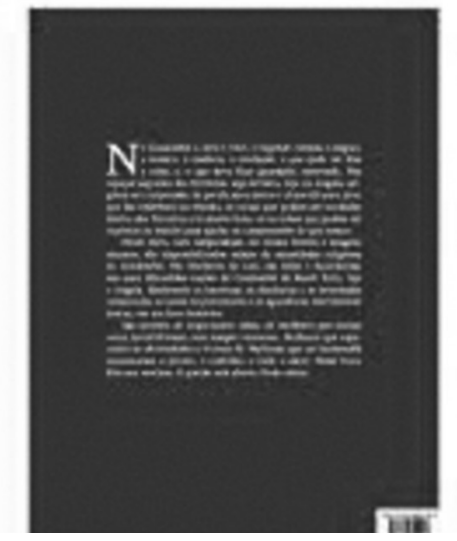

Fonte: Mulheres de Axé (REZENDE, 2013).

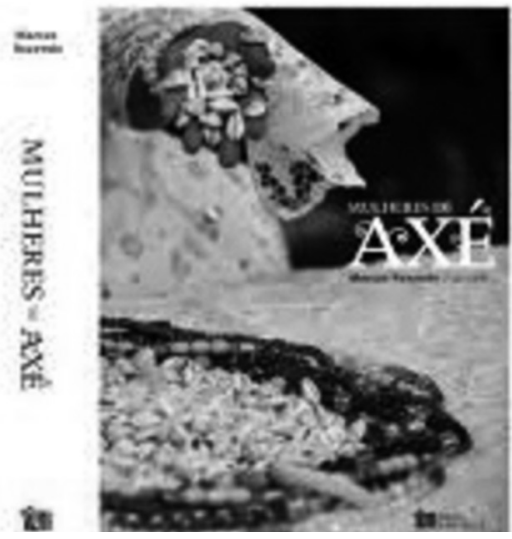

Figura 13

Imagem da capa do Livro Mulheres de Axé.

Para meu contentamento, logo que cheguei, tive a oportunidade de ser apresentado à senhora Elizabeth Ferreira Lopes, importante lideranças há mais de 25 anos, militante do movimento negro e defensora das comunidades quilombolas do município de Vitória da Conquista. Beta, como é conhecida por todos, imediatamente me levou ao encontro de outra importante liderança negra da cidade, o senhor Uelber Souza Barbosa, um jovem ativista das causas negras e da cultura afro-brasileira. Uelber e Beta faziam uma dupla que conduzia as ações dos Agentes Pastorais Negros(APNs) em todo o Sudoeste baiano. Sem demora, a 
dupla se transformou em um trio, e assim juntamos as ações de Beta e Uelber com as experiências e contatos com o movimento negro da capital e demos início a um trabalho que rendeu muitos frutos nos cinco anos que estivemos juntos.

A princípio, engajei-me nas duas ações que os APNs de Vitória da Conquista promoviam. A primeira, que já durava cerca de 20 anos, consiste no curso Pré-Vestibular Dom Climério, preparatório para jovens negros, quilombolas e pessoas de baixa renda. Essa ação tem uma importância fundamental na preparação desses jovens, principalmente após a criação das políticas públicas de inclusão, desenvolvidas pelos governos que chegaram ao poder no país a partir do ano de 2003, ou seja, a introdução, no Brasil, do sistema de cotas raciais, fomentando a esperança desses jovens de entrarem nas universidades, sendo o Dom Climério a única instituição que eles tinham para ajudá-los a conseguirem preparação eficiente e conquistarem uma vaga para o Ensino Superior.

Comecei trabalhando nesse projeto como professor voluntário de história do Brasil, mas logo fui me envolvendo com as questões administrativas e da coordenação pedagógica e, em pouco tempo, já era o principal parceiro de Beta e Uelber na construção das políticas públicas dos estudantes negros, secundaristas e universitários. Passamos a atuar junto com as universidades públicas da cidade, acompanhando o desempenho dos alunos e as políticas de permanência na universidade daqueles que tinham sido aprovados; lutamos ferrenhamente contra as fraudes das cotas, principalmente as dos estudantes quilombolas. 
A outra ação importante que os APNs desenvolvem há cerca de oito anos e que eu também passei a contribuir ativamente como colaborador e depois como membro do Conselho Fiscal e diretoria é a manutenção da Casa do Estudante Quilombola Zumbi dos Palmares, hoje Casa do Estudante Dandara dos Palmares, que surgiu a partir dos bons resultados que o Cursinho Dom Climério vinha conseguindo, ou seja, vários jovens quilombolas passavam no vestibular ou no ENEM.

Esses jovens muitas vezes não podiam permanecer na universidade por falta de condições financeiras satisfatórias e, principalmente, por não terem como morar na cidade. Nesse período, Beta e os companheiros do movimento negro da cidade resolveram montar uma casa para abrigá-los, sem custo de moradia, física e regimentalmente estruturada, e passou a receber os quilombolas universitários que começaram a ter toda estrutura para continuar os estudos. A Casa dispõe de dormitório coletivo para meninos e meninas, sala de estudo, refeitório, cozinha, área de lazer, internet e TV, além dos serviços de uma cozinheira e despesas de abastecimento de água e energia elétrica, por meio de fundos municipais e de pequena contribuição dos residentes, correspondendo, na época, à taxa de $\mathrm{R} \$$ 50,00 mensalmente.

A excelência do trabalho chegou a ser vencedora de edital do agosto da igualdade, Prêmio Manoel Faustino, promovido pela Secretaria Estadual de Promoção da Igualdade Racial da Bahia (SEPROMI) no ano de 2015, recebendo a importância de dez mil reais, revertida na melhoria das condições do espaço. A Casa contou, durante todo esse tempo (2008 a 2016), com o apoio incondicional da Prefeitura 
Municipal, que nunca mediu esforços para colaborar com o projeto, disponibilizando funcionários, fornecendo alimentação e transporte para atividades externas, quando solicitado. A figura 14, a seguir, ilustra a publicação sobre experiências da SEPROMI.

As ações promovidas por Beta e Uelber e por muitas outras lideranças do movimento negro de Vitória da

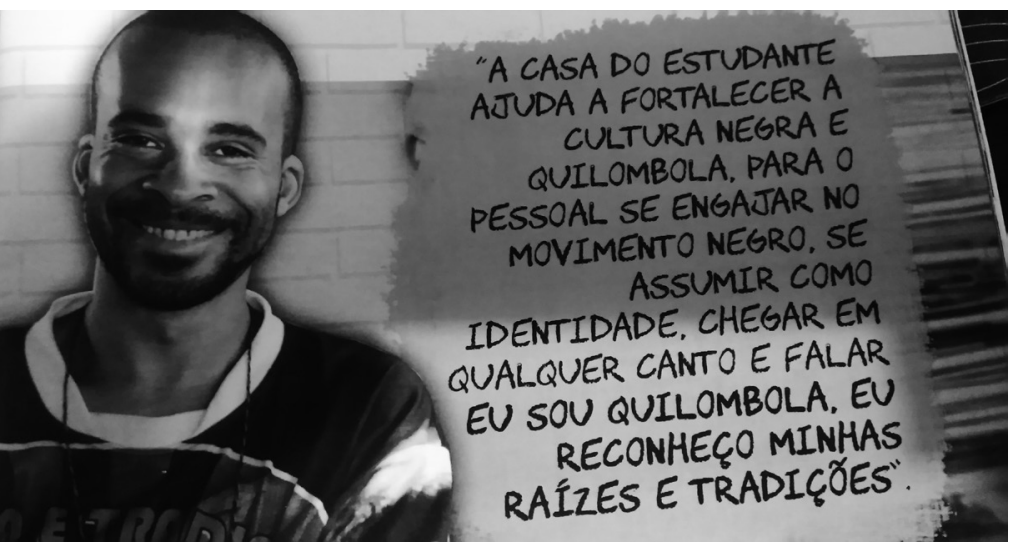

Figura 14

Catálogo sobre experiências, SEPROMI, Governo do Estado da Bahia. 
Conquista já haviam conquistado espaço no governo municipal quando eu cheguei ao município. Já existia, por exemplo, vinculado à Secretaria Municipal de Desenvolvimento Social (SEMDES), um Núcleo de Promoção da Igualdade Racial, porém sem orçamento próprio e dependente da boa vontade do secretário para desenvolver suas atividades; então, começamos a trabalhar para a construção de um organismo autônomo.

No começo não foi fácil, pois a maioria dos secretários de governo questionava o porquê de um órgão independente ao considerarem que já existia o Núcleo da Igualdade Racial. Podemos observar que o racismo vinha da própria instituição, sob o argumento da falta de orçamento e da dificuldade em fazer uma reforma administrativa, ou seja, tudo era motivo para não aprovar nosso pleito. Não desistimos e começamos outra estratégia, que consistiu no início de uma série de atividades e mobilizações de vários segmentos negros da cidade para mostrar ao prefeito que já existia uma organização social negra, o que justificava um órgão público que lhe representasse.

Realizamos rodas de conversas, rodas de capoeira em praça pública, seminários sobre religiões de matriz africana, encontros com as comunidades quilombolas, conferências de Promoção de Igualdade Racial, reuniões para elaboração do Plano de Igualdade Racial municipal, encontro de mulheres negras, feira de arte indígena, viagens culturais e carnavalescas para Salvador, com mulheres de Terreiro de Vitória da Conquista que participavam de vários eventos culturais e religiosos e desfilavam no carnaval de Salvador, no Afoxé Filhas de Gandhi, além da realização da Alvorada 
dos Ojás, evento organizado pelo Coletivo de Entidades Negras, no mês de novembro, em Salvador.

A atividade religiosa de amarrar os Ojás nas árvores passou a ser realizada também em Vitória da Conquista, com uma grande cobertura de vários veículos de comunicação, chamando a atenção de boa parte da população e também das autoridades municipais. Com toda essa mobilização, o prefeito foi sendo sensibilizado e acabou entendendo a necessidade da criação do tão desejado órgão de Promoção da Igualdade Racial da cidade. Assim, no ano de 2014, após reforma administrativa, o Núcleo de Promoção da Igualdade Racial se desvinculou da SEMDES e se transformou em uma Coordenação, com status de Secretaria de Igualdade Racial, ligada diretamente ao gabinete do prefeito, com dotação orçamentária e a autonomia necessária para organizar as políticas públicas raciais do município.

Após consulta do prefeito a algumas lideranças negras do município, meu nome foi indicado para ocupar o cargo de gerente de comunidade e povos tradicionais na Coordenação da Igualdade Racial. Nesse momento, tive oportunidade de aprofundar e estreitar ainda mais os laços com os Povos de Terreiros e as comunidades quilombolas, o que foi importante para compreender melhor a realidade desses segmentos sociais e a minha condição de ser negro.

Durante os dois anos à frente da gerência da Coordenação, tive oportunidade de conhecer de perto o cotidiano de algumas comunidades quilombolas e desenvolver atividades de formação política, organização comunitária, mutirões para construção de ações de sustentabilidade, encontros de mulheres quilombolas e intermediações de projetos de 
construções de casas do Programa Nacional de Habitação Rural - PNHR.

Em relação às comunidades de terreiros, a minha passagem pela Coordenação foi muito importante para entender ainda mais a necessidade de construir um trabaIho que permitisse o combate ao racismo religioso. Uma das principais atividades que tive oportunidade de coordenar nesse período foi o cadastramento de 45 casas de religião de matriz africana do território, entre terreiros de Candomblé de várias nações (Ketu, Jejê, Angola) e centros de umbanda. Nessas casas, tive oportunidade de conversar com várias crianças e adolescentes que relataram inúmeros casos de racismo religioso nas escolas.

Em dezembro de 2016, finalizava minha atividade como membro do governo municipal e, no ano seguinte, retomei com mais afinco as ações no movimento social, dedicando-me à organização de uma Coordenação Municipal do Coletivo de Entidades Negras e às ações do Centro de Educação Arte e Movimento (CETA), especialmente à escola de capoeira dirigida por Lázaro Vieira - ou Mestre Dendê (Figura 15), que desenvolvia um excelente trabalho com jovens da periferia da cidade, reintegrando muitos desses negros ao convívio social. Também contribuí com a formação do Coletivo Caminho dos Búzios, que consiste em uma rede de religiosos de matriz africana, fundado com a finalidade de construir uma organização legal de apoio aos terreiros de Candomblé e casas de umbanda da cidade. A Figura 15 mostra um grupo de jovens e de crianças na sede do grupo Arte e Movimento no dia de formatura e batizado dos alunos de capoeira. 
Com a saída da prefeitura, retornei, com maior carga horária, para minhas atividades em sala de aula. Era preciso atualizar as leituras, a preparação dos planos de aulas, os estudos sobre os novos conteúdos do Ensino Fundamental e Médio e as provas do ENEM. Assim, comecei a estudar e repensar a ideia de retomar a vida acadêmica, que tinha ficado para trás há algum tempo, devido a todas as atividades que optei por desenvolver na vida.

No início do mês de janeiro de 2017, já decidido a encontrar algum estudo voltado para as questões étnico-raciais na
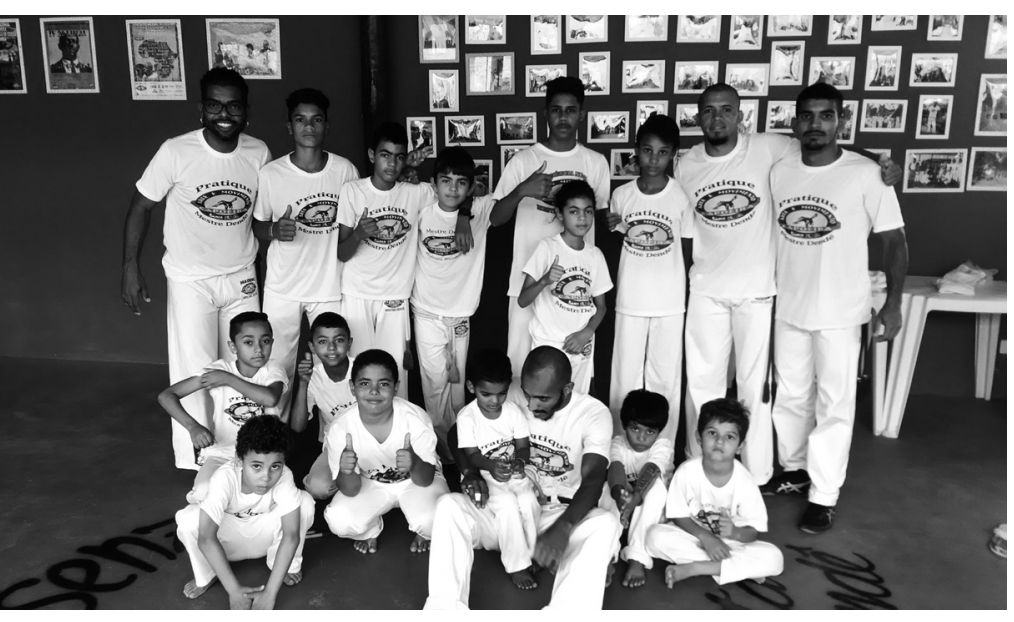

Figura 15

Fonte: Dados do pesquisador.

Grupo da escola

de capoeira Mestre

Dendê. 
universidade, encontrei a notícia que a UFSB tinha recebido aprovação da Coordenação de Aperfeiçoamento de Pessoal de Nível Superior (CAPES) para a realização da primeira turma do Programa de Pós-Graduação em Ensino e Relações Étnico-Raciais (PPGER). A partir dessa notícia, passei a acompanhar o site da universidade para saber o início do processo seletivo. Foram praticamente seis meses acompanhando e estudando o que podia sobre a temática racial e, enfim, no mês de julho, o edital foi publicado, dando início ao processo seletivo no mês seguinte.

Foram ofertadas cerca de 30 vagas e, para conseguir voltar à universidade, seria preciso vencer três etapas: aceitação do projeto, aprovação na prova escrita e na entrevista. Depois de tanta convivência nos terreiros e conversas com as crianças e jovens das casas, já sabia qual a temática que pretendia trabalhar: o racismo religioso que esses grupos sofriam na escola. Meu projeto foi aceito e, em agosto, recebi o resultado final das três etapas: fui aprovado. E um mês depois lá estava eu de volta à universidade, agora, para elaborar um trabalho que me conferisse o título de mestre.

A experiência adquirida durante o período de cumprimento dos créditos dos componentes curriculares foi algo completamente inovador. Os novos conceitos e autores apresentados pela equipe de professores me transformaram, principalmente ao levar em conta que já estava há tanto tempo distante da realidade acadêmica, envolvido profissionalmente com as questões da educação básica.

O primeiro momento foi difícil, pois precisava reelaborar os conhecimentos construídos até então, em função das novas informações e leituras propostas pelos docentes. 
Mesmo já tendo algum conhecimento de aspectos teóricos do movimento negro, conhecendo um pouco da sua história, como já relatei no texto anteriormente, as contribuições apresentadas pela professora Célia Regina da Silva, principalmente no que se refere às políticas públicas para as Relações Étnico-Raciais, abriram caminhos importantes para transformar as bases do projeto de intervenção de conclusão do curso.

Os autores estudados nesse componente curricular apresentavam conceitos e experiências práticas relativas à elaboração de políticas públicas para Educação das Relações Étnico-Raciais, como Nilma Lino Gomes, Vera Maria Candau, Kabengele Munanga, Maicelma Maia Souza, que ampliaram muito a minha visão sobre racismo, discriminação, intolerância e práticas pedagógicas inclusivas dessas minorias raciais.

\begin{abstract}
A educação reivindicada pelo movimento negro no Brasil, argumenta Nilma Lino Gomes, atravessa uma situação de tensão dupla entre configurar-se, de fato, como direito social para todos, e reconhecer e respeitar as diferenças. Ao assumir essa dupla função, acrescenta Gomes, a escola brasileira desde a educação básica até o ensino superior é responsável para construir práticas, projetos e iniciativas eficazes de combate ao racismo e de superação das desigualdades Raciais. (Gomes, op. cit. p. 102). Na perspectiva de Paulo Freyre, somos desafiados a construir uma Pedagogia do oprimido. No entanto, a questão racial nos ajuda a racializar ainda mais essa proposta. Somos levados a construir uma Pedagogia de Diversidade (GOMES, 2017, p. 102).
\end{abstract}

Novas informações apresentadas, como essa citada acima da professora Gomes, trouxeram importantes contribuições para o aperfeiçoamento do projeto inicial de 
trabalho, o que permitiu a reconstrução de ideias e pensamentos na estruturação de uma educação de base diversificada, multicultural e que contribuísse para a respeitabilidade e fim do racismo religioso, particularmente praticado contra crianças e jovens religiosos de matriz africana na escola.

O componente curricular proposto pela professora Francismary Alves Silva, ainda no primeiro quadrimestre, também foi de fundamental importância para o repensar das propostas iniciais do projeto. A princípio, o componente curricular "Imperialismos e descolonizações" parecia ser apenas uma disciplina que falaria de forma factual sobre as questões relativas ao processo de colonização europeia na África e na América, durante o período da Idade Moderna, entre os séculos XV e XVIII, e do fenômeno do imperialismo e do neocolonialismo no século XIX. No entanto, foi muito mais que isso. A sua formação de historiadora conseguiu trazer para mim uma visão muito contextualizada de todos os processos dominadores dos europeus sobre o novo mundo, de forma a relacionar o antigo sistema colonial com a colonização moderna. Além disso, ela introduziu os conceitos da decolonização; a ideia de que a expulsão material dos colonizadores determinava o fim da subalternidade e dependência dos colonizados foi substituída pela noção de que mesmo sem a presença física dos europeus, seus pensamentos e ações continuavam dominando a África e a América.

O texto feito nesse componente curricular foi muito importante e, por ter acontecido no primeiro quadrimestre, contribuiu de forma decisiva para preparar os estudos que iria fazer no, seguinte, com o professor Rafael Siqueira Guimarães, que introduziu muitos autores e conceitos teóricos 
novos para mim. Foi nesse momento que tive a oportunidade de conhecer o pensamento de Spivak (2010), que nos provocou a entender os aspectos teóricos e práticos da subalternidade, que corresponde à compreensão da submissão dos povos colonizados, e à importância de poder falar e rediscutir a dominação a partir do seu próprio lugar.

Os postulados de Grosfoguel (2016) me apresentaram o conceito de decolonialidade e perspectivas negras a partir das características de um projeto decolonial, bem como a produção do conhecimento e as narrativas a partir do "loci geopolíticos e corpos-políticos de enunciação" (GROSFOGUEL, 2016). Ele chama a atenção para o conhecimento a partir de uma perspectiva negra das Américas e do Caribe, além de conciliar os estudos com Anzaldúa (2000), que nos mostra a importância de agir coletivamente na tentativa de reconstruir a dignidade do sujeito dominado, para não ficar apenas reagindo à dominação, mas indo ao encontro e juntos agir contra o dominador.

Contudo, não é suficiente se posicionar na margem oposta do rio, gritando perguntas, desafiando convenções patriarcais, brancas. Um ponto de vista contrário nos prende em um duelo entre opressor e oprimido; fechados/as em um combate mortal, como polícia e bandido, ambos são reduzidos a um denominador comum de violência. O "contraposicionamento" refuta os pontos de vista e as crenças da cultura dominante por isso, é orgulhosamente desafiador. Toda reação é limitada por, e subordinada à, aquilo contra o qual se está reagindo. Porque o "contraposicionamento" brota de um problema com autoridade - tanto externa como interna representa um passo em direção à liberação da dominação cultural. Entretanto, não é um meio de vida. A uma determinada altura, no nosso caminho rumo a uma nova consciência, teremos que deixar a margem oposta, com o corte entre os dois combatentes mortais 
cicatrizado de alguma forma, a fim de que estejamos nas duas margens ao mesmo tempo e, ao mesmo tempo, enxergar tudo com olhos de serpente e de águia. Ou talvez decidamos nos desvencilhar da cultura dominante, apagá-la por completo, como uma causa perdida, e cruzar a fronteira em direção a um território novo e separado. Ou podemos trilhar uma outra rota. As possibilidades são inúmeras, uma vez tenhamos decidido agir, em vez de apenas reagir (ANZALDÚA, 2000, p. 2).

Além disso, o componente foi muito importante para o aprofundamento sobre o tema de minha pesquisa, pois, como dito, trouxe informações sobre subalternidade, decoIonização e submissão dentro de uma perspectiva racial e de gênero, introduzindo, desse modo, o repensar de algumas práticas na construção do meu projeto de intervenção.

O conteúdo estudado com a professora Ana Cristina Peixoto, relacionado ao componente curricular voltado para as práticas pedagógicas para educação étnico-racial nas escolas, acrescentou conhecimento satisfatório para que eu pudesse entender como construir ações possíveis para aplicação da legislação, principalmente da Lei n. 10.639 (BRASIL,2003) nos espaços escolares. Esses estudos mostraram a importância da formação do professor, do gestor e de todos os envolvidos no processo de ensino-aprendizagem em relação à educação étnico-racial.

Finalizando essa primeira etapa dos estudos, tive o grande prazer de aprender com a professora Cynthia de Cassia Santos Barra a importância do livro como potência transformadora da humanidade, além de conhecer com detalhes a história do livro. Discutimos por meio da obra de Foucault a ideia dos dispositivos, que consiste em ser 
um conceito multilinear, que combina estrategicamente campos de saber, relações de poder e modos de subjetivação, e conhecemos formas de livros novos, como o livro de comunidade apresentado em um dos nossos seminários de qualificação, realizado com a presença do professor peruano Elias de La Cruz. Foi a partir desse componente curricular que repensei a forma que construiria o produto final do mestrado, passando a concebê-lo como livro em forma de cartilha.

Essa caminhada até este momento permitiu mais do que esses novos conhecimentos adquiridos por meio dos professores nas salas de aula, pois, durante todo esse tempo, participamos de cinco seminários de qualificação das nossas pesquisas, com a participação de professores doutores de várias universidades latino-americanas, e de outros estados do Brasil, que contribuíram decisivamente na nossa formação e aperfeiçoamento do trabalho final.

Além dos conhecimentos adquiridos com os componentes curriculares do mestrado, e das leituras complementares, tivemos textos produzidos e aceitos para serem publicados em livros e revistas, que debatem temáticas referentes à decolonização, A educação multiculturalista, ao racismo religioso, bem como acerca da contribuição do movimento negro na construção das políticas públicas para aplicação da Lei n. 10.639 e a consequente diminuição do racismo religioso nos ambientes educacionais.

Outra maneira de aprimoramento e aprofundamento do conhecimento proporcionado pelo programa de pós-graduação foi a possibilidade de participar em alguns eventos de cunho acadêmico científico, que possibilitaram a troca 
de experiências com outros estudiosos de temáticas semeIhantes, além do enriquecimento do aprendizado.

Durante esse período, apresentei, entre outros: comunicação oral na Semana do Pertence de 2017, do Programa de Relações Étnico-raciais da Universidade Estadual do Sudoeste da Bahia - UESB (ODEERE); comunicação oral em grupo de trabalho do Fórum Social Mundial em 2017, em Salvador; mesa redonda na Faculdade Santo Agostinho, em Vitória da Conquista, na Jornada de Direitos Humanos da Faculdade de Direito; cursos e palestras em escolas de Ensino Médio da rede pública e privada, durante quase todo o mês de novembro de 2017, com a temática da lgualdade Racial; palestra sobre racismo religioso nas escolas, durante o Encontro Internacional de Educação na Universidade Estadual de Santa Cruz (UESC), em junho de 2018; mesa redonda também na UESC, dessa vez juntamente com a professora Ana Cristina Peixoto, minha orientadora, no $1^{\circ}$ Simpósio de Literatura Africana e Afro-brasileira; comunicação oral no Simpósio de Iniciação Científica, no dia 28 de novembro de 2019, na Faculdade Santo Agostinho, em Vitória da Conquista; e palestra com a temática Religiões de Matriz Africana e Racismo Religioso, na Faculdade de Tecnologia Científica (FTC), também em Vitória da Conquista, no dia 30 de novembro de 2019.

Finalizando essa análise, consegui perceber todo o processo que passei para me reconhecer como um homem negro e avalio que foi muito importante toda essa "viagem interior" e todo o aprendizado recente. Agora percebo que introjetei a ideia da luta pela igualdade racial e passei a viver cotidianamente enfrentando desafios para promover uma 
educação cada vez mais inclusiva, multiculturalista, que discuta as questões raciais, culturais, sociais, humanas, econômicas, de forma inter-relacionada, com o objetivo de contribuir para promover o respeito, a diversidade e alteridade.

Nem mesmo esteticamente eu consigo mais me apresentar como me apresentei durante quase 50 anos da minha vida, de uma forma muito mais próxima do

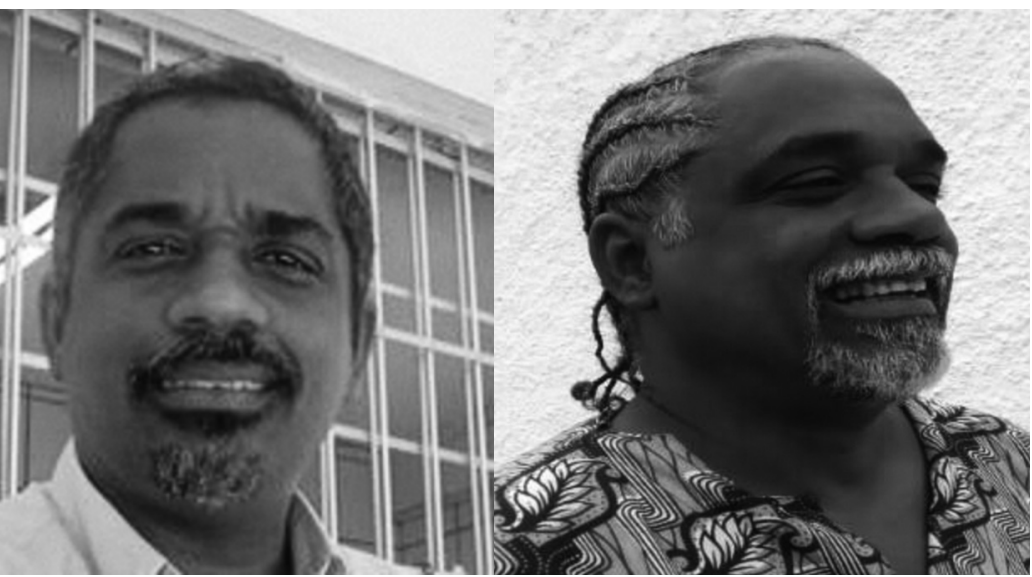

Figuras 16 e 17

Fotografias do autor, 2005 e 2018. 
embranquecimento do que na minha negritude, como podemos perceber nas imagens ao lado (Figuras 16 e 17).

Como pôde ser observado pelos relatos e análises aqui apresentados, a minha história de vida profissional e cidadã está intrinsecamente relacionada com a problemática que apresento nesta obra.

Entendo a importância de toda esta produção como fundamental para uma continuidade destes estudos e destas ações sociais de combate ao racismo religioso daqui para frente, de forma mais cotidiana e permanente na minha existência, esperando que esta obra possa contribuir e instigar outras pesquisas nesta temática.

A seguir, será apresentada a pesquisa direta realizada, abrangendo a descrição dos conceitos metodológicos que a embasaram e os resultados obtidos por meio das técnicas e fontes utilizadas. 



\section{Pesquisa de campo: dando voz às crianças de Candomblé}

A partir das leituras realizadas para construção desta obra, considera-se que os postulados do multiculturalismo crítico, defendidos principalmente pelo autor McLaren (1997), são os que podem melhor embasar esta pesquisa. Esse modelo de investigação possibilita a observação a partir de uma pedagogia de resistência, inquirindo os sistemas culturais preestabelecidos.

Entender multiculturalismo e educação pressupõe analisar concepções e práticas pedagógicas baseadas em um movimento teórico que nasceu a partir da segunda metade do século XIX, nos Estados Unidos, e que se difundiu pelo mundo ocidental como forma de enfrentamento dos conflitos surgidos por conta de questões econômicas, políticas, étnico-raciais e culturais na luta para combater discriminações e preconceitos, haja vista as dificuldades de grupos e indivíduos de acolher e conviver com a pluralidade e as diferenças. O relato de McLaren (2000, p. 86-87), expresso no texto a seguir, apresenta de que forma a educação feita 
com base nos princípios do multiculturalismo crítico pode levar à construção de uma sociedade mais justa e igualitária, tanto no aspecto moral quanto material capitalista.

O pós-modernismo de resistência oferece aos educadores que estão trabalhando com educação multicultural uma maneira de interrogar a localidade, o posicionamento e a especificidade do conhecimento (em termos de localização de raça, classe e gênero dos alunos e alunas) e de gerar pluralidade de verdades (em vez de uma verdade apodítica construída em torno da norma invisível do eurocentrismo e da etnicidade branca). Ao mesmo tempo, esta perspectiva também situa a construção do significado em termos dos interesses materiais que estão operando na produção de efeitos de verdade - isto é, na produção de formas de inteligibilidade e de práticas sociais. Consequentemente, educadoras que trabalham com a perspectiva de um pós-modernismo de resistência tornam-se capazes de questionar as assunções políticas e as relações de determinação sobre as quais as verdades sociais estão fundamentadas, tanto nas comunidades onde elas trabalham quanto na sociedade maior da qual elas fazem parte.

O conceito do multiculturalismo acaba ganhando mais visibilidade, principalmente nos países americanos, a partir do momento do crescimento e expansão do sistema capitalista que se torna cada vez mais global.

Economicamente, o novo modelo é representado pela chamada globalização econômica, que significa a internacionalização do capital, tendo como base a produção, distribuição e consumo de bens e serviços, organizados por meio de uma estratégia mundial na intenção de promover uma padronização dos gostos dos consumidores de todos os lugares do mundo, de uma forma muito agressiva sobre as identidades culturais diversas, visto que a globalização 
pode significar homogeneizar, diluindo identidades, destruindo marcas do que os colonizadores chamam de culturas inferiores. Para Siqueira e Pereira (2002 apud MORANTE; GASPARIN, 2010, p. 3),

\begin{abstract}
[...] a sociedade moderna, tipicamente industrial, [...] sofreu uma transformação radical, sendo caracterizada hoje como uma sociedade globalizada, impulsionada pela explosão das informações e intensificação das comunicações em nível mundial. Este cenário já não pode ser ignorado pela educação, pois o impacto desses processos no cotidiano escolar é cada vez maior. A problemática atual das escolas, principalmente nas grandes cidades, local onde se multiplicam tensões e conflitos já não pode ser reduzida aos aspectos relativos à estruturação interna da cultura escolar, necessita ser repensada para incorporar na sua própria concepção estas realidades sociais e culturais.
\end{abstract}

A partir de tantas tensões e desafios originários da globalização, que contribui decisivamente para aprofundar a complexidade da questão da centralidade da cultura, enxergamos os princípios do multiculturalismo crítico do teórico Mc Laren (1997). Eles possuem condições para explicar e ajudar na construção de uma escola de maior respeito às diversidades, principalmente culturais e religiosas.

O multiculturalismo não é somente um movimento social em defesa das minorias negras, mas também incorpora-se em uma abordagem curricular contrária a toda forma de preconceito no espaço escolar. Conforme afirmam Silva e Brandim (2008, p. 56), o multiculturalismo

Inicialmente, constitui-se desvinculado dos sistemas de ensino, incorporado na sua maioria pelos movimentos sociais, 
especialmente os grupos sociais negros. O eixo orientador do movimento é o combate ao racismo e a luta por direitos civis, Gonçalves e Silvia (1998) situam o início do movimento no final do século XIX, com as lutas dos afrodescendentes, que buscavam a igualdade de exercício dos direitos civis e o combate à discriminação racial no país.

Observando o pensamento inicial multiculturalista, percebemos que podemos relacioná-lo com as ideias de educadores brasileiros, principalmente com a professora Nilma Lino Gomes, que em seus escritos propõe um modelo de currículo que possa iniciar um processo de decolonização do Ensino Básico e Superior no Brasil, em oposição ao atual modelo curricular ainda frequente nas escolas brasileiras, que reitera o caráter colonizador eurocêntrico. Neste mesma linha Silva e Brandim (2008, p. 60) defendem o multiculturalista como instrumento para construção de uma diversidade cultural capaz de construir uma educação cidadã e inclusiva:

Para começar, o multiculturalismo é uma estratégia política de reconhecimento e representação da diversidade cultural, não podendo ser concebido dissociado dos contextos das lutas dos grupos culturalmente oprimidos. Politicamente, o movimento reflete sobre a necessidade de redefinir conceitos como cidadania e democracia, relacionando-os à afirmação e à representação política das identidades culturais subordinadas. Como corpo teórico questiona os conhecimentos produzidos e transmitidos pelas instituições escolares, evidenciando etnocentrismo e estereótipos criados pelos grupos sociais dominantes, silenciadores de outras visões de mundo. Busca, ainda, construir e conquistar espaços para que essas vozes se manifestem, recuperando histórias e desafiando a lógica dos discursos culturais hegemônicos. Os estudos sobre os fenômenos culturais partem da necessidade de 
compreensão dos mecanismos de poder que regulam e autorizam certos discursos e a outros não, contribuindo para fortalecer certas identidades culturais em detrimento de outras.

A grande meta do pensamento multiculturalista a ser atingida é a equidade, com base no acesso e permanência escolar de todas as crianças e jovens, independentemente das diferenças étnicas, sexuais, religiosas. Além disso, visa preparar todos para uma convivência plural e diversa.

Sendo assim, os procedimentos de pesquisa utilizados têm uma dupla função: a de permitir a análise e compreensão do problema enunciado e, ao mesmo tempo, contribuir para o processo de resistência dos Povos de Santo. As áreas da pesquisa foram a cidade de Itabuna, focalizando o Terreiro Ilê Axé Odara, na região Sul do estado da Bahia, e a cidade de Salvador, capital da Bahia, no Terreiro llê Axé Oxumarê.

As técnicas utilizadas na pesquisa foram levantamentos em fontes secundárias e outras de caráter primário, que contemplaram a pesquisa documental e pesquisa direta aplicada nos terreiros de Candomblé, principalmente com as crianças e jovens, mas também com seus pais, com as autoridades religiosas dos espaços pesquisados, além de observações na rede de educação formal. A seguir, apresenta-se o Quadro 1, que contém a síntese das técnicas com suas respectivas fontes de consulta utilizadas na pesquisa.

A construção desta obra consistiu em uma pesquisa qualitativa, por meio da elaboração de entrevista, com roteiro estruturado, aplicada diretamente pelo pesquisador, direcionada às crianças e jovens dos Terreiros, como também a outras pessoas da Casa (Babalorixá, Egbomes, 
Quadro 1. Síntese das técnicas, fontes e instrumentos utilizados na pesquisa.

\begin{tabular}{|l|l|}
\hline TÉCNICAS & FONTES \\
\hline $\begin{array}{l}\text { PRIMÁRIAS } \\
\text { Pesquisa direta. }\end{array}$ & $\begin{array}{l}\text { Observação de participante. } \\
\text { Entrevistas com crianças e jovens dos } \\
\text { Terreiros. Autoridades religiosas dos } \\
\text { Terreiros. }\end{array}$ \\
\hline $\begin{array}{l}\text { SECUNDÁRIAS } \\
\text { e iconográficas. }\end{array}$ & $\begin{array}{l}\text { Pais dos entrevistados. } \\
\text { Publicações: livros, artigos }\end{array}$ \\
\hline acadêmicos, matérias jornalísticas. \\
& Internet. \\
& $\begin{array}{l}\text { Imagens: fotos, cartazes. } \\
\text { Vídeos: filmes, documentários, } \\
\text { entrevistas. Dissertações de } \\
\text { mestrado. }\end{array}$ \\
\hline
\end{tabular}

Fonte: Elaboração própria. 
Ogãs e Ekedes). Além desta pesquisa direta nessas fontes primárias, utilizamos outras fontes, tais como: documentos do acervo das instituições religiosas pesquisadas, notícias de periódicos, jornais, documentos governamentais voltados para a Política de Promoção da Igualdade Racial e atas de reuniões do Coletivo de Entidades Negras, onde as pautas foram voltadas para as questões do racismo religioso.

Foram também realizadas as observações dos participantes sobre o comportamento das crianças e jovens entrevistados durante sua estadia no Terreiro, tanto no dia a dia, como nos dias de celebração religiosa. As informações foram registradas de forma organizada, desde o início da pesquisa, classificadas e tratadas qualitativamente por meio de descrição e análise do conteúdo dos fenômenos observados pelo autor nas várias fontes já definidas, de acordo com as questões e objetivos do estudo, assim como com o referencial teórico-metodológico adotado.

Espera-se, dessa maneira, que esta obra contribua para o fortalecimento da autoestima e, também, que possibilite aos jovens assumirem suas condições de religiosos de matriz africana na sociedade em geral e no ambiente escolar, em particular, superando as adversidades que se apresentam.

Em seguida, serão detalhadas as entrevistas realizadas nos dois terreiros escolhidos, com as crianças e jovens e o Sacerdote de cada Terreiro. 


\subsection{TERREIROS ILÊ AXÉ ODARA E ILÊ AXÉ OXUMARÊ}

A pesquisa direta ocorreu principalmente por meio de observações e de questionários realizados nos Terreiros selecionados, sendo um no município de Itabuna, Ilê Axé Odara, e outro em Salvador, llê Axé Oxumarê, conforme já mencionado. A escolha do primeiro local se justifica por estar situado na região Sul da Bahia, em Itabuna, onde está localizada a UFSB. A orientação inicial foi que este autor mantivesse o foco dos estudos no mesmo território em que cursou os componentes curriculares, para facilitar seu trabalho. O outro espaço religioso escolhido, em Salvador, foi em função de ser já frequentado pelo pesquisador desde o ano de 2007, como relatado no capítulo 4 desta obra.

A parte da pesquisa relacionada às fontes orais de investigação teve início na cidade de Itabuna, região Sul do estado da Bahia, que está localizada a cerca de 426 quilômetros de distância da capital da Bahia, ou a 333 quilômetros via ferry boat. Possui área total de $432.244 \mathrm{~km}^{2}$ e é o quinto município mais populoso da Bahia, e no Nordeste brasileiro ocupa o décimo lugar. Sua população, conforme estimativas do IBGE de 2018, alcançou 212.740 habitantes (IBGE, 2018).

Esse Terreiro pesquisado está localizado atualmente na Rua José Alves Franco, n. ${ }^{\circ} 1355$, Bairro São Roque, área periférica e popular da cidade. O llê Axé Odara, Casa de Candomblé da nação Angola, tem como seu líder espiritual (Babalorixá) Pai Gildo de Kaulange (Obaluayê). A origem da Casa se deu há cerca de 40 anos, inicialmente no Bairro de Fátima, próximo à localização atual do llê. O Terreiro consiste em uma instituição religiosa e social, sem fins lucrativos que, além das atividades sagradas de religião de matriz 
africana, utiliza o espaço para outras atividades culturais, como a prática da capoeira, maculelê, samba de roda, realização de curso de formação e profissionalização de costura e bordado, oficinas de cabelos crespos e de fabricação de instrumentos, como atabaques e agogôs.

As fotos abaixo (Figuras 18 e 19) apresentam o Barracão do Terreiro, local onde são realizadas as cerimônias públicas para homenagear os Orixás.

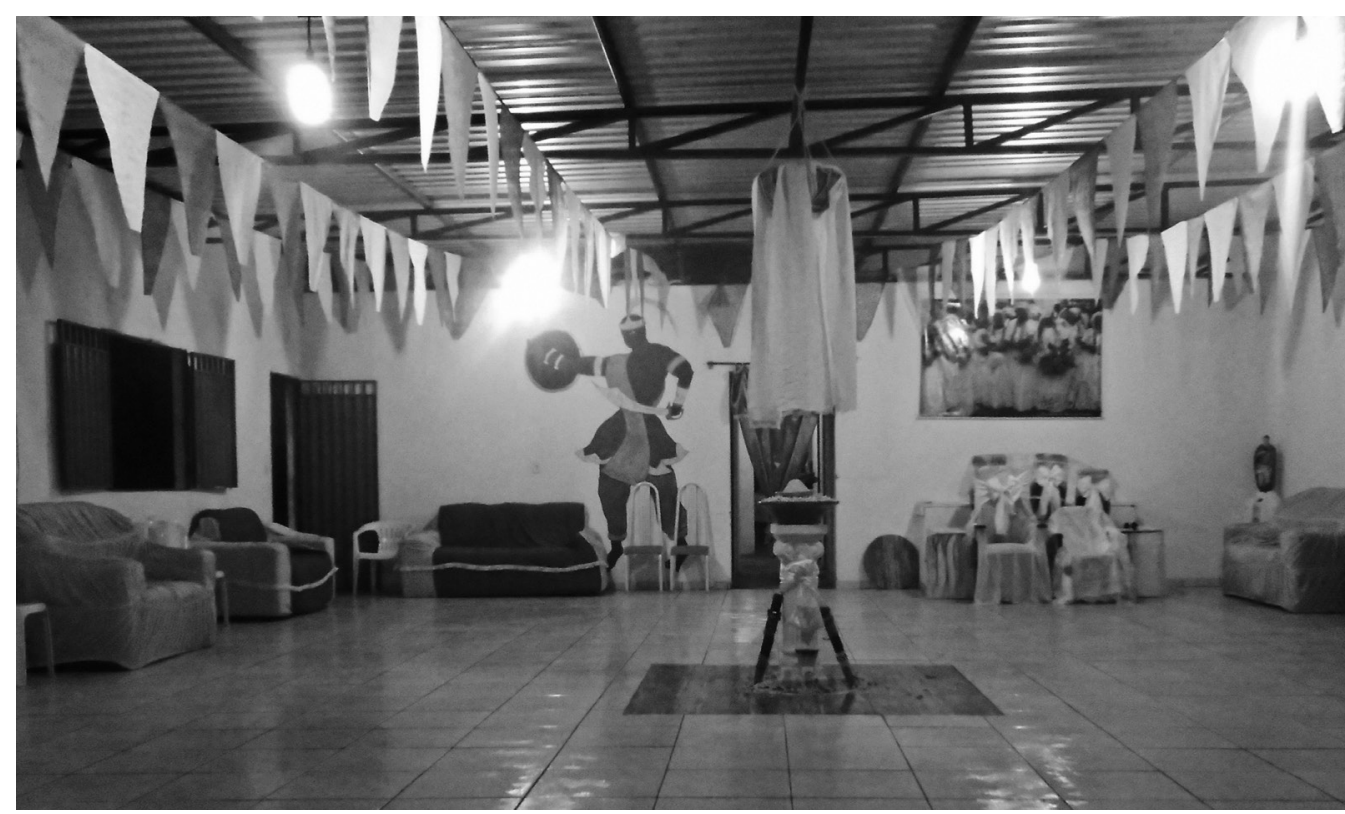

Fonte: Dados do pesquisador.

Figura 18

llê Axé Odara. 


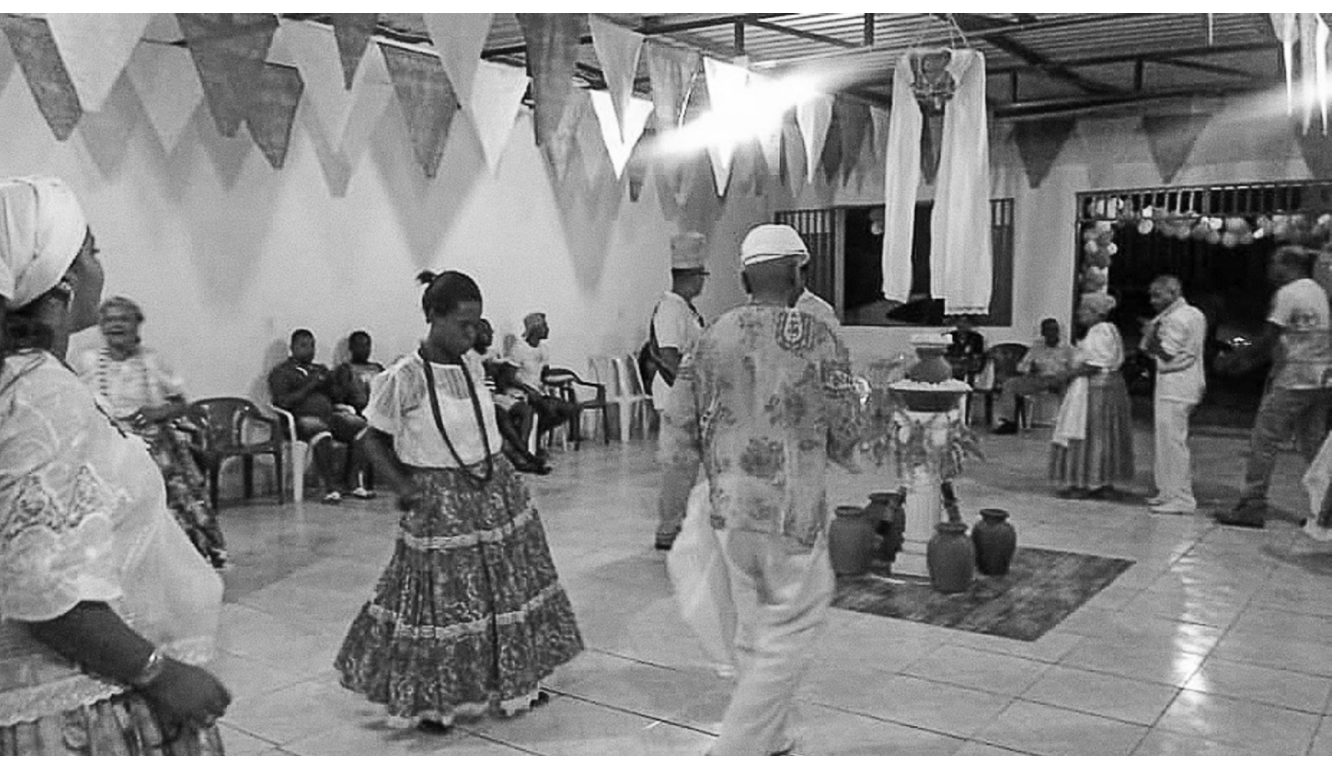

Fonte: Dados do autor

Figura 19

Ilê Axé Odara em

festa.

Conforme visto anteriormente, a segunda instituição religiosa escolhida para participar da pesquisa oral, a Casa de Oxumarê, é o Terreiro que o autor frequenta e tem o cargo de Ogã suspenso para o Orixá Yemanjá. Esta Casa situa-se na Avenida Vasco da Gama, n. 343, bairro Federação, na cidade de Salvador, Bahia.

A cidade de Salvador, primeira capital do Império Português no Brasil, foi fundada em 1549 pelo primeiro governador geral do Brasil, Tomé de Souza. Localizada inicialmente na Baía de Todos os Santos, foi construída de forma estratégica, aproveitando sua estrutura geográfica, assim, foi dividida em duas partes, uma baixa, voltada para as atividades comerciais, e uma alta, local da administração municipal e de defesa. 


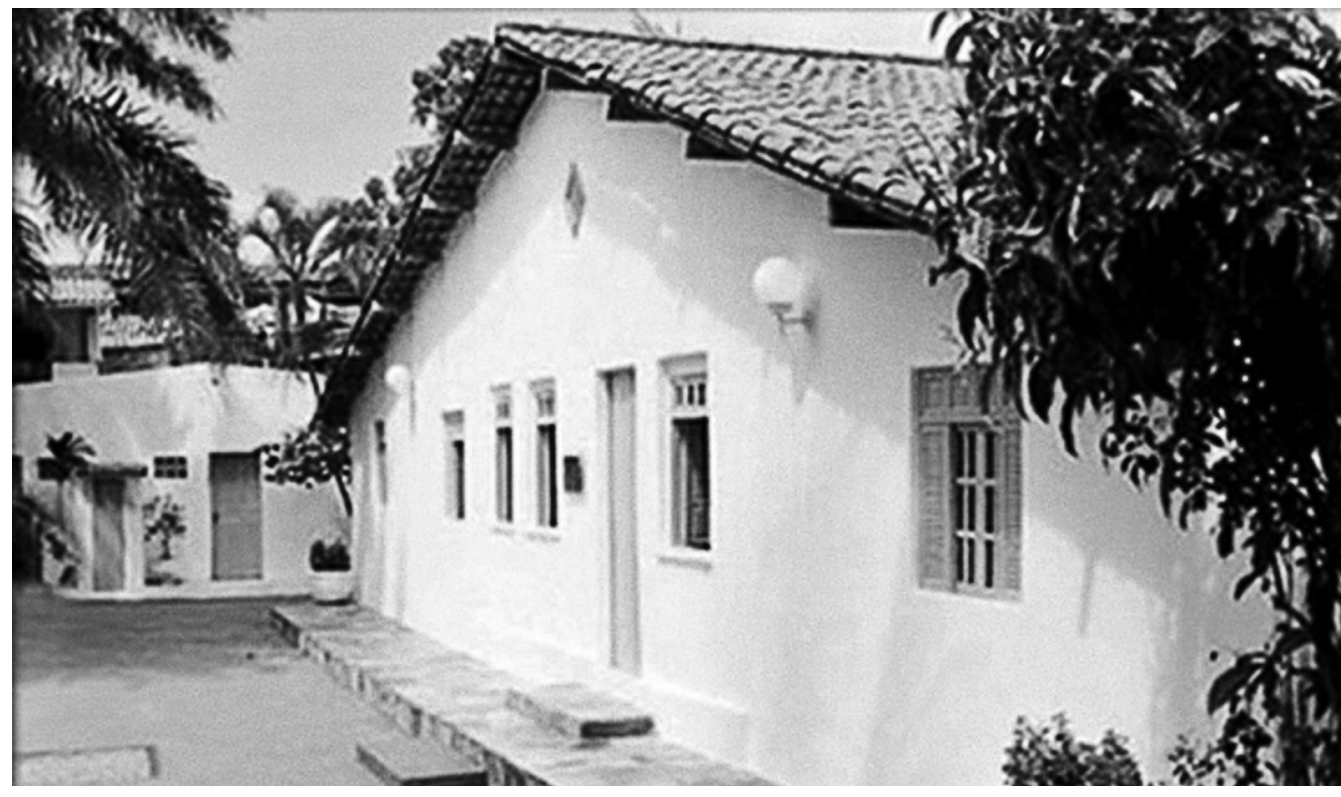

Fonte: Site llê Axé Oxumarê, s.d

Com o passar do tempo, a cidade avançava na direFigura 20

Fachada da Casa de Oxumarê.

ção norte, ocupando áreas do centro histórico, e na direção sul, tomando as regiões de vales onde surgiram grandes fazendas, que com seus desmembramentos foram formando regiões periféricas e ocupadas por uma população simples e de maioria negra. Uma das regiões formadas foi a antiga Estrada Dois de julho, hoje Avenida Vasco da Gama, onde há cerca de 180 anos nasceu a Casa de Oxumarê (Figuras 20 e 21), um dos terreiros mais antigos da cidade, atualmente liderado pelo Babalorixá Babá Pecê.

Vale lembrar que o terreiro de Candomblé, no momento do seu nascimento, precisava estar localizado distante do centro da cidade, pois era preciso fugir da forte 


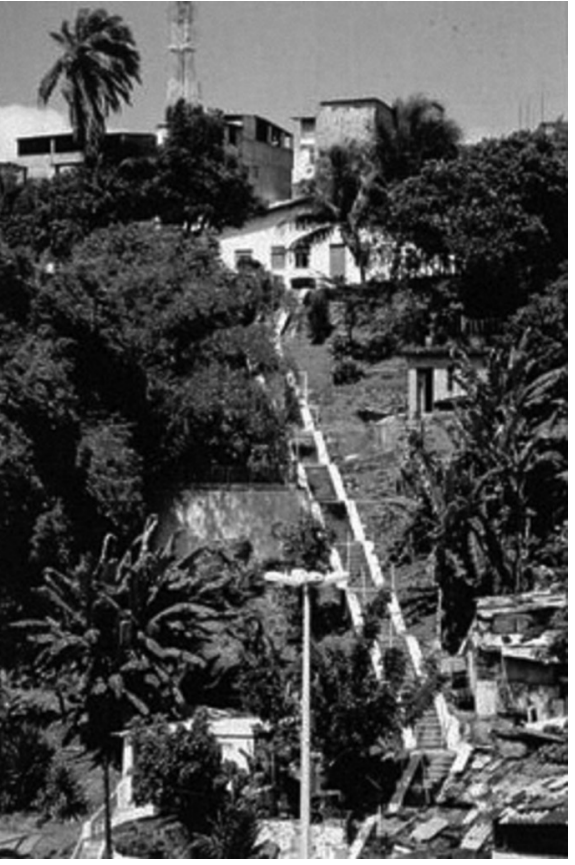

Fonte: Site llê Axé Oxumarê, s.d

Figura 21

Casa de Oxumarê.

perseguição das autoridades policiais que não permitia a realização de cerimônias religiosas desse tipo.

A história da Casa de Òsùmàrè remete à época da formação do candomblé no Brasil. A sua origem remonta ao início do século XIX e foi marcada pela luta e resistência de africanos escravizados que, obrigados a abandonarem suas terras e laços familiares, não renunciaram à sua cultura e fé. Seu fundador Bàbá Tàlábí, oriundo da antiga cidade Kpeyin Vedji, localizada a noroeste de Abomey, aportou em Salvador em 1795 na condição de escravizado. Foi um sacerdote com grande propriedade para introduzir e difundir o culto aos Òrìsà no Brasil, por pertencer a uma das mais relevantes famílias de Culto à Sakpata (Ajunsún), na África. Após curar seu senhor através da ciência Yorùbá, passa a viver como liberto e se dedica ao comércio iniciando trocas entre a capital e o recôncavo baiano. Por volta de 1820, na Cidade de Cachoeira, Bàbá Tàlábí ajuda a fundar o culto a Ajunsún no calundu do Obi Tedó ("fundação da família"). Este local tornar-se-ia a referência primordial da Casa de Òsùmàrè no Brasil (2012). 
5.2 ENTREVISTAS: SACERDOTES E CRIANÇAS E JOVENS DOS TERREIROS

Inicialmente, foram realizadas consultas aos Babalorixás dos Terreiros escolhidos, já mencionados acima, para confirmar o interesse e conveniência em participarem da pesquisa e autorizarem, formalmente, as entrevistas com as crianças e jovens das Casas. Foram assinados, como é recomendado pelas convenções acadêmicas, os Termos de Concordância.

Após os acordos estabelecidos, foram realizadas as entrevistas com cada um dos Pais de Santo. Passa-se a apresentar, a seguir, o resultado destas entrevistas realizadas com os Sacerdotes: Pai Gildo de Obaluayê, do Terreiro llê Axé Odara, em Itabuna, e Babalorixá Pecê de Oxumarê, do Terreiro de Oxumarê, em Salvador.

\subsubsection{SACERDOTES}

\section{PAI GILDO - ITABUNA (Figura 22)}

Na conversa inicial, Pai Gildo fez questão de contar como chegou ao Candomblé, o que se deu de forma muito difícil, visto que, apesar de já sentir a necessidade de seguir o caminho religioso, somente depois de uma séria doença que inicialmente lhe fez perder 27 quilos e abrir o corpo todo em feridas, além dos médicos o desenganarem, buscou solução do problema no Candomblé. Após passar por vários terreiros, sem solução, chegou na casa de uma senhora iniciada 


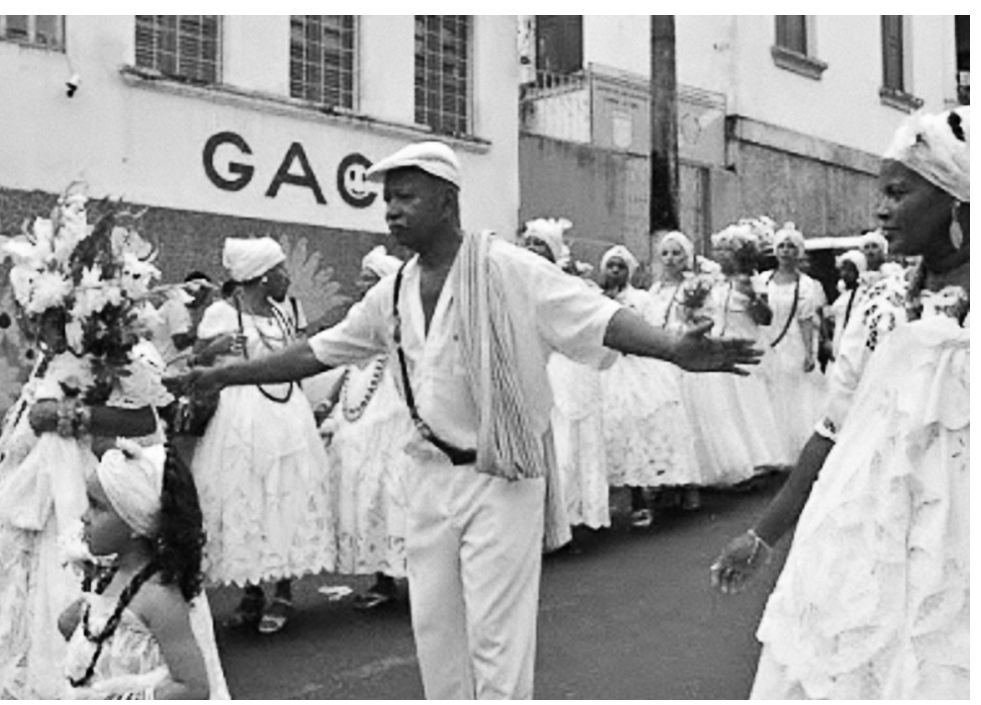

Fonte: Jornal Bahia Já, 2016

Figura 22

Pai Gildo na Lavagem do Beco do Fuxico. ao Orixá Nanã, que cuidou dele, levando a sua cura e a sua iniciação no Candomblé da nação Angola.

Após todo esse sofrimento, Pai Gildo entendeu que só construindo "esta obra religiosa" teria saúde. As principais atividades, segundo ele, são as festas aos orixás, além de várias ações sociais que o Terreiro desenvolve com crianças e jovens da comunidade, que não têm oportunidade de frequentar a escola no turno integral, e assim vão ao Terreiro no turno oposto à aula para participarem das várias atividades educativas oferecidas pelo llê. O Terreiro também faz, há mais de 20 anos, a lavagem do Beco do Fuxico, uma das mais tradicionais festas da cidade, que consiste na abertura do carnaval de Itabuna.

A educação das crianças do Terreiro é feita conjuntamente com os pais, dentro de suas casas, que acompanham o 
crescimento delas, ampliando a educação familiar. As crianças aprendem com os mais velhos, principalmente por meio da observação. "Aqui temos a nossa própria pedagogia, que é feita através da prática do aprender fazendo", relatou Pai Gildo.

O Babalorixá ainda fez questão de frisar que na cidade de Itabuna também existe preconceito com os adeptos das religiões de matriz africana: "não recebemos nenhum apoio do poder municipal, todos os terreiros são obrigados a pagar IPTU e as igrejas de outras denominações não, não recebemos nada de políticos, nada das organizações governamentais".

A fala do Pai de Santo referente à falta de incentivo governamental para atividades do Terreiro reflete a realidade desse espaço; porém, cabe ressaltar que, há algum tempo, principalmente a partir da década de 2000 , diversas políticas públicas têm sido construídas em âmbito federal, estadual e municipal, embora exista ainda muito a se fortalecer. Projetos de apoio às comunidades tradicionais foram criadas e publicizadas por meio de editais públicos, inclusive com ministério e secretarias estaduais e municipais de promoção da igualdade racial, atendendo à reivindicação e pressão por parte da sociedade organizada.

Sobre o racismo, Pai Gildo observa que as pessoas de terreiro quando saem nas ruas da cidade (Itabuna) vestidas de roupas de orixás são discriminadas. "Aqui na cidade, é difícil encontrar uma baiana vendendo acarajé, pois se estiver trajada com suas vestimentas próprias ninguém compra, eu mesmo já fui chamado de macumbeiro e feiticeiro várias vezes nas ruas da cidade", enfatiza Pai Gildo. 
Quando perguntado sobre a discriminação a crianças e jovens do Terreiro, especialmente nas escolas, ele disse que elas "chegam aqui várias vezes se queixando de muitos atos de racismo religioso nas suas escolas, até mesmo os professores discriminando elas". As crianças de terreiro, de acordo com o Babalorixá, perdem suas amizades da escola e muitas terminam deixando a instituição. Pai Gildo relata: “já acolhi algumas crianças que passaram o ano aqui por não quererem ir mais para a escola, muitos dos Pais de Santos de Itabuna chegam a evitar sair de casa por causa da perseguição proveniente do racismo sofrido".

\section{BABÁ PECÊ - SALVADOR (Figura 23)}

Em 1991, Babá Pecê, Sivanilton Encarnação da Mata, filho biológico de Mãe Nizete, assume o Terreiro, contando com apoio das anciãs da Casa de Oxumarê, que tanto aguardavam a profecia de Ogum em seu nascimento. Babá Pecê nasceu no terreiro de Oxumarê, no dia da sua celebração. Babá Pecê, com seu amor e carisma, tornou-se uma referência de conduta sacerdotal por todo o território nacional e internacional. O reconhecimento de Babá Pecê no âmbito religioso e político veio de todo o trabalho por ele desempenhado para a promoção e defesa não só do povo de santo, mas também por proteger a infância, a comunidade negra e aqueles em situação de maior vulnerabilidade. Até hoje, Babá Pecê tem o comando da casa e foi com ele que começamos as entrevistas sobre a questão do racismo religioso.

O Babalorixá da Casa de Oxumarê foi categórico ao afirmar que para ele uma das piores coisas por que passam 


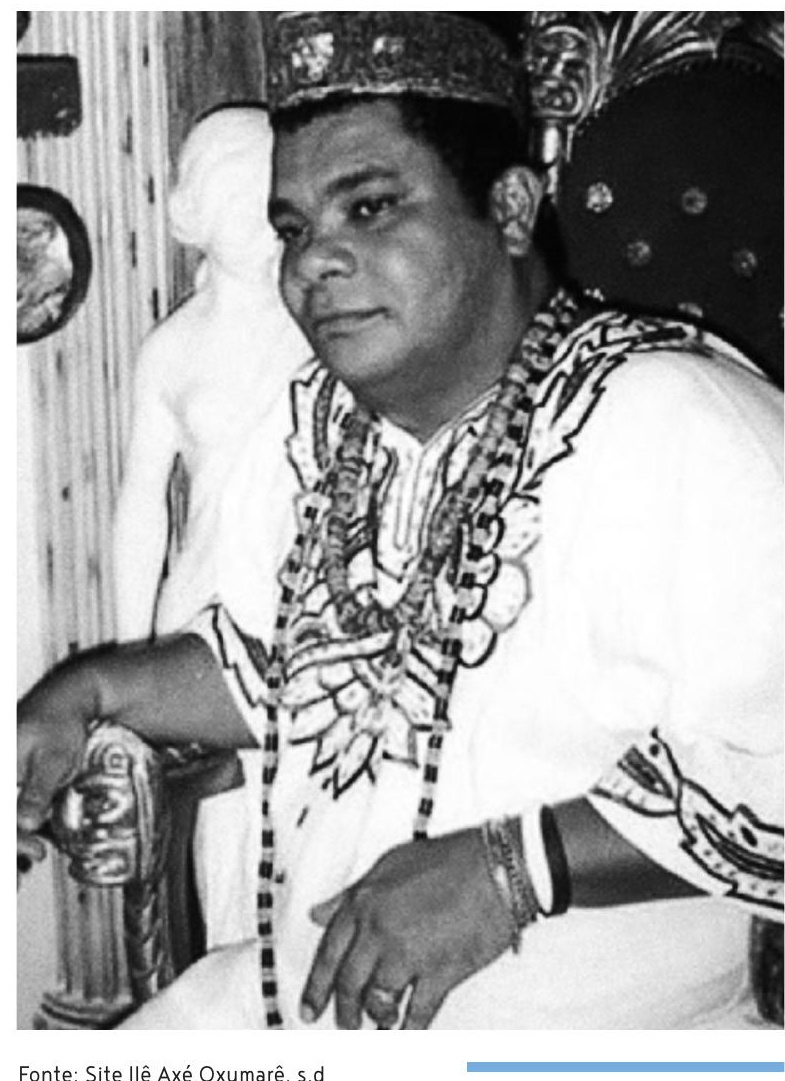

Fonte: Site llê Axé Oxumarê, s.d

as religiões de matriz africana é o racismo religioso. Afirmou que, durante todo esse tempo de sacerdócio, acompanha de perto os atos de discriminação, perseguição e racismo contra o povo de santo cotidianamente. Para ele, os ataques, principalmente promovidos pelas igrejas pentecostais, são os mais frequentes, tendo relatado que já presenciou ações violentas contra as religiões de matriz africana, tanto na sua Casa, quanto em inúmeras outras localizadas em Salvador e também no interior do estado. Por causa disso, Babá

Figura 23

Babá Pecê de Oxumarê saudando os Orixás. 
Pecê, por ser uma liderança religiosa de um dos mais antigos terreiros de Salvador - llê Axé Oxumarê, que também era membro do Coletivo de Entidades Negras, sempre esteve à frente de todas as ações e manifestações em defesa da liberdade religiosa do povo de santo.

Foi ele quem liderou um grande movimento pela manutenção de uma árvore sagrada, localizada dento da área do Oxumarê, onde a prefeitura desejava construir uma passarela para travessia de pedestres, o que iria interferir profundamente nos aspectos físicos, morais e religioso da instituição. A luta e mobilização foi intensa, culminando com a mudança do local da construção da passarela e a preservação do espaço sagrado do Terreiro.

Outro caso de racismo religioso relatado por Babá Pecê, e já referido neste trabalho, foi o ocorrido no Terreiro de Mãe Rosa - llê Axé Oyá Onipó Neto, que acabou por ter parte do espaço demolida pela prefeitura de Salvador. Embora tenha sido contestada por ação de reintegração de posse pela justiça, a ação da liderança do Babalorixá da Casa de Oxumarê, juntamente com outras instituições do movimento negro e de defesa dos direitos humanos, conseguiu resistir e reverter a situação, por meio de uma intensa e ampla mobilização.

Babá Pecê acredita que o racismo religioso sofrido pelas religiões de matriz africana, especialmente com as crianças e jovens nos espaços escolares, "é fruto de uma grande ignorância, falta de segurança e principalmente falta de fé e respeito ao outro". O Babalorixá afirma também que "sonha em que um dia todos os segmentos religiosos possam desenvolver seu papel de pregadores do amor e entendam 
que todos somos iguais e, portanto, temos que respeitar o desejo e vontade do outro ser de qualquer religião".

Após ouvir os Sacerdotes, autoridade máxima na hierarquia dos Terreiros, passou-se a entrevistar as crianças e jovens, seguindo o roteiro pré-estabelecido (Apêndice), como previsto no projeto de pesquisa.

5.2.2 CRIANÇAS E JOVENS DO ILÊ AXÉ ODARA E ILÊ AXÉ OXUMARÊ

Inicialmente, passa-se a caracterizar o universo de crianças e jovens que participaram diretamente deste estudo. Como pode ser observado no Quadro 2, Na próxima página, foi entrevistado um total de nove crianças e jovens, sendo cinco do Terreiro llê Axé Odara e quatro do llê Axé Oxumarê. Além disso, foram observados, de forma menos sistemática, outros integrantes dos Terreiros com a mesma faixa etária dos pesquisados diretamente.

Na intenção de resguardar os entrevistados, na sua maioria menores de idade, suprimimos seus nomes de batismo e optamos por identificá-los com a palavra Erê, como são chamados os seres espirituais infantis no Candomblé. Para diferenciá-los, associamos a palavra Erê ao nome do orixá de cabeça de cada uma das crianças e dos jovens.

A escolha dessa denominação não foi uma criação pessoal, ela foi inspirada na dissertação de mestrado da professora Souza (2010), por meio da qual foi usada a expressão Erê para caracterizar as crianças que foram entrevistadas. 


\section{Quadro 2 - Caracterização das crianças e jovens entrevis-}

tados, ano de referência - 2018.

\begin{tabular}{|c|c|c|c|c|c|c|}
\hline & $\begin{array}{c}\text { NOME ADOTADO } \\
\text { NA PESQUISA }\end{array}$ & $\mathrm{COR}^{*}$ & SEXO & IDADE & ANO & INSTITUIÇÃO \\
\hline \multirow{5}{*}{$\begin{array}{l}\text { ILÊ AXÉ } \\
\text { ODARA }\end{array}$} & Erê de lansã & Negra & $\mathrm{F}$ & 17 & $9^{\circ}$ & Pública \\
\hline & Erê de Yemanjá & Parda & $\mathrm{F}$ & 17 & $9^{\circ}$ & Pública \\
\hline & Erê de Obaluayê & Branco & M & 08 & $3^{\circ}$ & Privada \\
\hline & Erê de Oxum 1 & Negra & $\mathrm{F}$ & 18 & $3^{\circ}$ & Pública \\
\hline & Erê de Xangô & Negra & $\mathrm{F}$ & 09 & $2^{\circ}$ & Pública \\
\hline \multirow{4}{*}{$\begin{array}{r}\text { ILÊE AXÉ } \\
\text { OXUMARÉ }\end{array}$} & Erê de Oxum 2 & Negra & $\mathrm{F}$ & 13 & $7^{\circ}$ & Pública \\
\hline & Erê de Nanã & Negro & M & 10 & $5^{\circ}$ & Privada \\
\hline & Erê de Oxumarê & Negra & $\mathrm{F}$ & 12 & $7^{\circ}$ & Público \\
\hline & Erê de Ayrá & Negro & M & 18 & $3^{\circ}$ & Pública \\
\hline
\end{tabular}

Fonte: Dados do pesquisador. 
A pesquisa direta ocorreu no período de março de 2018 a fevereiro de 2019, sendo as entrevistas realizadas nos meses de setembro de 2018 a janeiro de 2019. Segue abaixo a caracterização dos entrevistados (Quadro 2).

Passaremos agora à análise do perfil dos Erês entrevistados pelo processo de autoidentificação. Conforme observa-se no Quadro 2, ao lado, sete dos nove entrevistados se autodeclararam como negros, um como pardo e um como branco. Essa predominância se mostra coerente com o fato de se tratar de um espaço religioso de matriz africana, cuja origem histórica é de pessoas que aportaram no Brasil por meio do processo de diáspora.

Das crianças e jovens, as do sexo feminino são maioria entre os entrevistados em ambos os Terreiros (seis dos nove no total). Embora essa escolha não tenha sido direcionada, a convivência nesses espaços possibilitou perceber uma maior disposição destas ao serem informadas do que se tratava a pesquisa, pois elas sofrem mais racismo religioso, pelo que tem sido observado, do que os do sexo masculino. A faixa etária dos pesquisados está entre 8 e 18 anos, na época das entrevistas, sendo coerente com a escolaridade. Predomina a frequência às escolas públicas, observando-se que apenas dois deles estudam em escolas da rede privada de ensino (os de menor idade), o que mostra que as crianças e jovens desses Terreiros residem em regiões periféricas, normalmente no entorno desses espaços. 


\section{ERÊ DE IANSÃ}

Erê de lansã é uma jovem de 17 anos, considera-se negra, reside na cidade de Itabuna, estuda no Instituto Municipal Aziz Maron, no turno noturno, cursando o $9^{\circ}$ ano do Ensino Fundamental e na sua escola não tem aula de religião. Há seis anos ela frequenta o Terreiro e está passando por processo de iniciação no Candomblé para "fazer o seu santo", ou seja, ser consagrada ao Orixá "dono do seu Ori" (cabeça). Seus pais e avós são também frequentadores do Terreiro.

Assume-se como candomblezeira e, embora ainda não tenha uma função específica no llê, faz tudo que se pede: varre a casa, lava os pratos e arruma o barracão. Entende o terreiro como um espaço de educação e considera o aprendizado do espaço melhor que o da escola, pois "o Pai de Santo fala da África e dos ensinamentos dos ancestrais, ensina como se comportar na vida, pedindo licença, respeitando os mais velhos e aprendendo através da observação e do cuidado que o Babalorixá tem a ensinar". Ou seja, prefere o Terreiro à escola.

Todas as colegas da escola sabem que ela é do Candomblé, ela mesma contou no bate-papo. Os professores também sabem porque ela mesma falou, e sempre se coloca a favor do Candomblé em discussões na escola. No turno noturno não percebeu nenhum ato de racismo religioso contra ela. Relatou, também, que adora ser do Candomblé; vai de branco para a escola quando está em período de obrigação e nunca sofreu preconceito, sempre se assumiu, porém, apesar disso, disse que já escutou "brincadeiras de mau gosto em relação ao Candomblé", mas isso não a abalou. 
"Já fui chamada de macumbeira e fazedora de coisa ruim, mas não liguei”.

Fica claro que apesar de Erê lansã não ter se sentido ofendida ou até não perceber a gravidade dos acontecimentos, não podemos desprezar o que foi relatado por ela ao dizer que algumas vezes "foram feitas brincadeiras pejorativas em relação a sua religião". Levar essas ofensas como forma de brincadeira é uma das maneiras que o racismo tem de esconder a realidade que passa o povo negro e religiosos de matriz africana deste país, tal prática não deixa de ser um mecanismo de tentar diminuir e descaracterizar o racismo religioso tão presente no Brasil.

\section{ERÊ DE IEMANJÁ}

22. Rituais religiosos das religiões de matriz africana onde normalmente os participantes se desfazem de um bem material em homenagem a um orixá ou entidade espiritual. Limpeza de uma pessoa de uma casa, de uma família.

Erê de lemanjá é uma jovem de 17 anos, identifica-se com a cor parda e se define como alguém que não é negra nem branca. Ela estuda no Colégio Estadual Sesquicentenário (CISO) onde cursa o $9^{\circ}$ ano. Há quatro anos ela estuda na mesma escola e nunca teve aula de religião, "no CISO nem se fala em religião". Declara-se candomblezeira, frequenta o Terreiro desde criança e há um ano é consagrada ao Orixá lemanjá. Durante todo o processo de pesquisa no Terreiro, esta Erê de lemanjá estava na Casa, próxima e cuidando dos afazeres e do Pai de Santo. Os ensinamentos do terreiro para ela são fundamentais, pois ensinam a fazer as comidas, conhecer as folhas e suas utilidades, preparar os "banhos de folha", arrumar os Ebós ${ }^{22}$. Relatou que "no terreiro se aprende ensinando ou observando o Pai e as mais velhas, enxerga o terreiro como uma escola, pois, ajuda na 
convivência fora do terreiro". Para ela existem duas pedagogias: a formal e a do cotidiano no Terreiro.

Todos os colegas sabem da sua religião, ela mesma contou, pois no período da "obrigação" teve que ir vestida de branco e com os aparatos do processo de iniciação no Candomblé, a "feitura". A professora e diretora descobriram por causa de uma grande briga com uma colega que a discriminou e ofendeu por causa da sua religião. A escola teve uma postura séria de combate ao acontecido e evitou outros problemas. Porém, a Erê de lemanjá relatou que, caso continuasse sofrendo racismo, deixaria de frequentar a escola. Isso reforça a ideia de que racismo religioso é um dos motivos das altas estatísticas de evasão escolar verificadas.

A entrevistada também relatou que nunca levou ninguém da escola para o Candomblé e que na escola tem muitos colegas evangélicos que a maltratam e a ofendem, principalmente quando está em "obrigação", já que nesse período ela não vai para a escola de farda, e sim de roupa de terreiro, já que a instituição permite. Porém, as ofensas são recorrentes: "lá vem a macumbeira, lá vem a feiticeira". Ela nunca escondeu sua identidade religiosa, mesmo sofrendo o preconceito.

\section{ERÊ DE OBALUAYÊ}

Erê de Obaluayê tem oito anos e frequenta o Terreiro desde o dia em que nasceu. Ele se identifica como alguém que possui pele branca, estuda na escola Cristão Filhos do Rei, onde cursa $03^{\circ}$ ano do Ensino Fundamental I. Algumas vezes tem aula de religião na escola, mas ele não participa, 
porém, é obrigado a participar das festas. A instituição que o entrevistado estuda é privada e evangélica, sempre acontece nas festas a presença de grupos musicais cantando canções religiosas e todos são obrigados a participar.

Ele frequenta o Candomblé há oito anos, a mãe frequenta o Candomblé às vezes e o pai é o primeiro Ogã da casa. No Terreiro ele aprende a respeitar os mais velhos e - Orixá, a tocar os atabaques, falar outra língua (Bantu), e sempre observar o que os mais velhos estão fazendo.

Os colegas de sala não sabem que ele é do Candomblé, porque, como ele disse, "se eu falar vão me chamar de macumbeiro", "zombarem" de mim, "se eu falar vão rir de minha cara e falar muitas coisas ruins". Os professores e funcionários da escola também não sabem que ele é do Candomblé, pois ele esconde sua religião, bem como sua melhor amiga na escola, que também pertence à mesma religião. Ele esconde sua prática religiosa na escola para não sofrer perseguição, pois uma colega e amiga sua se expôs, aparecendo na escola com as roupas brancas e contas no pescoço, foi maltratada e sofreu muita discriminação, ficando, então, vários dias sem ir à escola porque estava com medo e vergonha, medo de apanhar e vergonha de ser do Candomblé. O entrevistado gosta de ser do Candomblé e vai enfrentar as pessoas que falem mal da sua religião.

\section{ERÊ DE OXUM 1}

Erê de Oxum tem 18 anos e concluiu o terceiro ano do Ensino Médio no Colégio Estadual Felix Mendonça, na cidade de Itabuna. Ela identificou-se, a princípio, como de 
cor parda, mas após algumas perguntas se colocou como negra. Na sua escola não tem aula de religião, porém nas aulas de história se falava do tema, inclusive, sobre o Candomblé. Ela se diz católica e do Candomblé, pois, além de vir no terreiro, vai à igreja católica. Quando está em um espaço fora do Candomblé, inclusive na escola, diz ser adepta da outra religião.

A entrevistada frequenta o Terreiro há cerca de quatro anos, está em processo de iniciação, já participa de quase todos os rituais religiosos da Casa e logo estará sendo iniciada como Yaô. Os pais dela são do Candomblé, mas os irmãos não frequentam esse espaço religioso. Ela reconhece - Terreiro como uma verdadeira escola para a vida, pois lá aprende os afazeres práticos e os valores éticos e morais, como a construção do sentimento de igualdade, de respeito às diferenças de raça e credo. Terminou o Ensino Médio escondendo a sua condição de candomblezeira, e quando alguém pergunta sobre sua religião, declara-se católica. Ela verbalizou:

Vejo o Terreiro como um lugar que me ensina a ser uma pessoa melhor, saio daqui sabendo que devo ajudar as pessoas e respeitar ao próximo, não discriminar nem por religião, nem por sua cor. Na escola ninguém sabia que eu era do candomblé, não queria ser zoada, eu escondia minha condição, já presenciei uma colega sofrer uma grande discriminação e isso fez ela se afastar da escola, então não me apresentava de candomblé. Queria que essa cidade me enxergasse como uma pessoa normal, me sinto abalada psicologicamente, nem professores nem diretores da escola sabiam que eu era do candomblé. Muita vontade de defender, ninguém da escola veio conhecer o terreiro, eu me sinto feliz no terreiro, uma pessoa mais alegre, adoro meus irmãos do terreiro, somos 
23. Palavra de origem

Yorubá que designa os filhos de santos no candomblé já iniciados, mas que ainda não completaram o período de sete anos da iniciação. uma verdadeira família. Não consigo usar roupa de candomblé na rua, só quando vamos a atividades coletivas e todas se vestem de baianas, aí nos sentimos protegidas. Só após os sete anos uma Yaô se tornará uma Egbome ${ }^{23}$ (Erê de Oxum 1, 2018).

Como relatou, Erê de Oxum 1 presenciou uma colega bem próxima sofrer uma agressão verbal muito grave devido a ida à escola usando roupas brancas e contas, portanto ela optou por se esconder. De acordo com ela, "isso foi muito ruim", pois sabia que, se alguém descobrisse, ela seria maltratada. Relatou ainda que, quando estava na escola, se sentia outra pessoa, era triste e afastada das colegas, não tinha alegria porque não podia ser quem ela era, só se sentia feliz, satisfeita e completa quando estava no Terreiro.

\section{ERÊ DE XANGÔ}

Erê de Xangô tem nove anos de idade e está cursando - $2^{\circ}$ ano do Ensino Fundamental I na Escola Municipal Everaldo Cardoso. Ela se reconhece como negra e, embora frequente o Terreiro há sete anos, não diz na escola que é do Candomblé "para não sofrer bulem [bullying] das colegas", ela acredita que seria "isolada do convívio com as amiguinhas se soubessem que ela frequenta Terreiro".

Na sua escola, às vezes, tem aula de religião, existe uma professora que ministra essas aulas das quais Erê de Xangô participa. Ela contou que o assunto mais falado na aula é sobre Deus, nunca se falou do Candomblé. Ela continua afirmando, na entrevista, que é católica e do Candomblé, disse que toda sua família frequenta a igreja e o terreiro, e quando alguém pergunta na escola qual a sua religião, ela 
diz ser católica. "Eles (os colegas) dizem que candomblezeira é macumbeiro e abusam, zoam".

No Candomblé ela gosta de dançar, ver os Orixás e brincar com os Erês. Além de aprender a dançar, também é orientada a respeitar a natureza e se sente muito feliz no Terreiro. Na escola, "quando falam mal do Candomblé, eu saio de perto e vou para outo lugar, fico isolada". Nem os colegas nem a direção ou professores e coordenação sabem que ela pertence ao Candomblé. Ela acredita que, se soubessem, teria que pedir à mãe para sair da escola, porque não ia aguentar, pois, "mesmo gostando (do Candomblé), não tenho coragem de dizer, já presenciei em outra sala um colega ser tratada mal na hora do recreio, muitos iam atrás dele abusando e chamando de macumbeiro, ele teve que sair da escola".

5.2.4 CRIANÇAS E JOVENS DO ILÊ AXÉ OXUMARÊ

Neste terreiro foram entrevistadas quatro crianças ou jovens entre 6 e 18 anos, cujos resultados estão apresentados individualmente a seguir,

\section{ERÊ DE OXUM 2}

Erê de Oxum 2 tem 13 anos de idade, considera-se negra, estuda na Escola Estadual Maria Romana Calmon, está cursando $\circ 7^{\circ}$ ano do Ensino Fundamental II e questiona a qualidade do ensino da instituição. Na escola não tem aula de religião e não se discute a temática. A entrevistada 


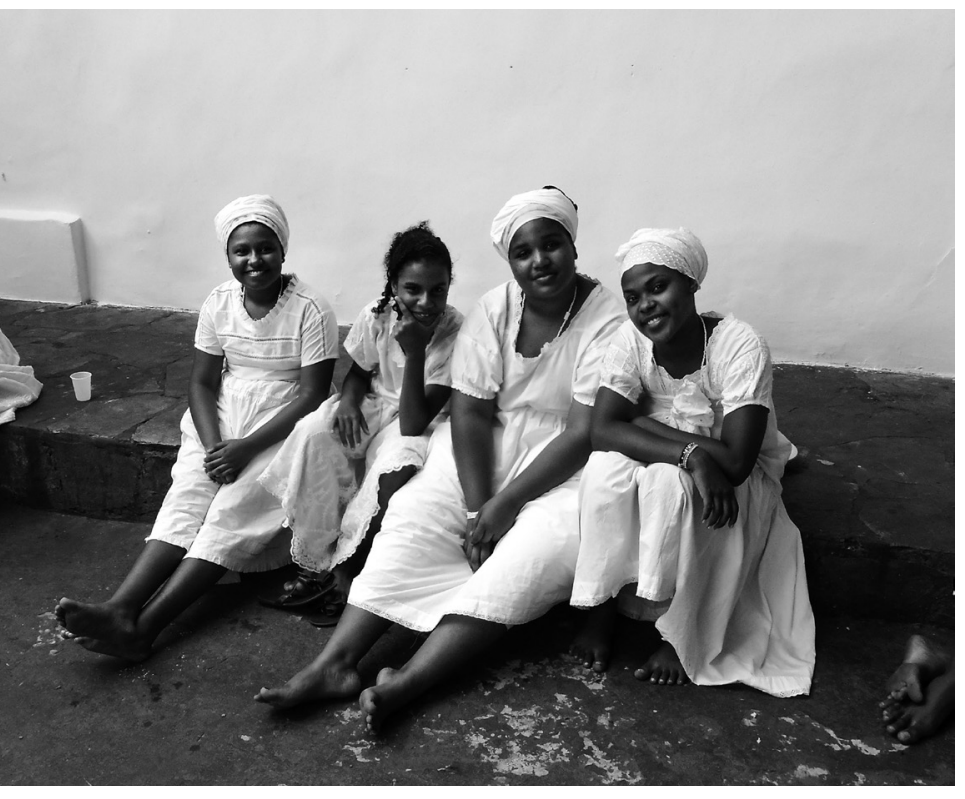

Fonte: dados do pesquisador

Figura 25

Crianças e jovens do Terreiro llê Axé

Oxumarê.

declarou-se religiosa de matriz africana desde o seu nascimento, disse que já nasceu no Candomblé, foi iniciada para o Orixá Oxum com apenas dois anos de idade e seus pais também são do Candomblé. Quando perguntada como aprendia as coisas no Candomblé e se via o terreiro como um espaço de educação, ela respondeu de forma muito segura:

Na verdade, eu nem sei como isso acontece, pois eu já nasci aprendendo, desde que era bem pequena eu vinha para o terreiro e ficava olhando, observando e repetindo as coisas feitas pelos mais velhos, sinto que todo este aprendizado que tenho neste espaço é bem diferente dos ensinamentos da escola, aqui eu aprendo a ser mais humilde, respeitar mais as outras pessoas, compreender 
o que os mais velhos me ensinam, na verdade o candomblé me faz uma pessoa muito feliz e respeitadora (Erê de Oxum 2, 2018).

Na escola ninguém sabia que ela era do Candomblé, nem as colegas, nem os professores, nem a direção, ela nunca falou porque sentia receio de se expor, mesmo depois de iniciada, respondia que frequentava algumas vezes e se dizia católica.

Quando a entrevistada fez as "obrigações de sete anos" do Candomblé e teve que ir para a escola usando roupas brancas e elementos religiosos que a identificavam como uma adolescente de Terreiro, foi isolada pelos colegas que olhavam para ela com "rosto de nojo e desrespeito", tendo sido chamada de macumbeira. Dessa forma, foi afastada das atividades, passou a se distanciar ainda mais e sofrer muito. Ela contou que o seu "sofrimento abalou profundamente a mãe, que não entendia o que estava acontecendo, porque ela chorava tanto ao retornar da escola e sentia-se muito deprimida, tendo vontade até de abandoná-la", relatou, ainda, que o pior foi assistir ao sofrimento da sua mãe, que ficava muito triste em ver a filha naquela situação.

Erê de Oxum 2 contou que a situação só melhorou um pouco quando ela identificou na sala de aula dois colegas que também eram do Candomblé, tendo se unido a eles e, juntos, tiveram força para reagir às discriminações que sofriam. Outro fato que a fortaleceu foi contar a sua mãe o que acontecia, daí esta foi à instituição e conversou com os gestores, tendo eles passado a interferir, por meio de ações esclarecedoras, sobre a situação de racismo religioso pela 
qual estava passando a aluna, junto aos alunos e professores, amenizando estes atos.

Ao final da conversa, a entrevistada disse que apesar de tudo que aconteceu, pelo Candomblé, enfrentaria tudo novamente. Para ela, a sua religião "é tudo na vida, é onde aprendo, ensino, estudo e me torno uma pessoa melhor para mim e para os outros, todos os dias".

\section{ERÊ DE NANÃ}

Erê de Nanã tem apenas 10 anos de idade, declara-se negro, estuda no Colégio Nabuco, escola da rede particular, e cursa o quinto ano do Ensino Fundamental I. Na sua escola não tem aula de religião na grade curricular e pouco se fala sobre o tema.

Com apenas dois anos de idade ele foi suspenso a Ogã, pelo Orixá Nanã da Egbome Jéssica. Com muita firmeza ele afirma ser do Candomblé, disse que já nasceu no terreiro e é sobrinho do Pai de Santo. Seus pais também são do Candomblé, sendo o pai Ogã e a mãe Egbome. Descreve com detalhes a importância da educação que recebe no Terreiro para sua formação na vida com os ensinamentos da religião que, segundo ele, são aprendidos por meio da sua observação e também das ações práticas, como pegar uma folha sagrada, cuidar dos atabaques, limpar os Santos, varrer o Terreiro, limpar os bichos. Ele relata que recebe diariamente ensinamentos que vão formando sua personalidade. 
Erê de Nanã demorou muito de se apresentar na escola como religioso de matriz africana, apesar dos diretores da escola serem do Candomblé. Porém, ele declarou que

\begin{abstract}
Na sala tinha muitos alunos evangélicos que falavam o tempo todo mal da minha religião e eu ficava com vergonha de falar, pois sabia que sofreria racismo, mas este ano eu resolvi assumir, no meio da aula, pedi a palavra à professora e disse em voz bem alta "eu sou do terreiro Oxumarê, sou suspenso a Ogã e o candomblé não é isso que vocês estão falando, se quiserem saber mais vamos a uma festa de Santo". A partir deste dia me senti aliviado, não precisava mais fingir que era católico, apesar de durante um período ter sido bastante desprezado pelos colegas, me senti aliviado por poder assumir minha condição religiosa. (Erê de Nanã, 2018).
\end{abstract}

Ele disse que, depois do seu anúncio, pôde questionar as ofensas e dizer para os colegas o que realmente era o Candomblé, tendo sido a sua declaração importante, inclusive, para uma das suas professoras. que também era do Candomblé e nunca teve coragem de assumir. E "com a minha atitude ela sentiu-se fortalecida, e depois deste dia várias vezes passamos a falar sobre a cultura e religião africana". Finalizando, Erê de Nanã disse que o Candomblé é sua vida e que nasceu ali e jamais sairá do terreiro, "é ali que aprendo, até mais do que na escola".

\title{
ERÊ DE OXUMARÊ
}

Erê de Oxumarê tem 12 anos de idade, autodeclara-se preta, estuda na escola municipal Visconde de Cairu e cursa o $7^{\circ}$ ano do Ensino Fundamental II. É Ekede suspensa aos dois anos de idade para o Orixá Oxumarê de Babá Pecê, Pai 
de Santo do terreiro, e é filha da Egbome Viviane de Oxóssi, portanto, praticamente nasceu na Casa de Oxumarê e sempre está no terreiro.

A entrevistada declarou que nunca escondeu a sua religião de ninguém, que colegas, professores e direção sabiam que era do Candomblé e que isso fez com que, durante alguns anos, ela fosse muitas vezes ofendida por todos; sempre que ela chegava para participar das brincadeiras não era bem aceita, e os colegas mandavam ela procurar Jesus porque ela tinha "parte" com o diabo.

Erê de Oxumarê teve uma reação diferente da maioria das crianças e jovens discriminados por causa da sua religião, pois, enquanto a maioria ficava calada e sofria muito internamente, ela partiu para o enfrentamento, apresentando um bom nível de conhecimento dos fundamentos da religião, assim ela enfrentava a todos, argumentando e mostrando que Candomblé não é nada daquilo que eles estavam falando, pedia respeito e dizia que "cada um tem o direito de seguir a religião que escolher".

Ao final, ela disse que considera terreiro de Candomblé um lugar de muitos ensinamentos, onde ela aprende muitas coisas importantes para sua vida, principalmente cuidar das folhas, já que, de acordo com ela, "sem folha não existe Candomblé, sem folha não existe vida, não existe nada".

Apesar de assumir e enfrentar ser do Candomblé, ela não deixou de sofrer o racismo religioso na escola por vários anos, porém, encontrou uma forma de reagir, utilizando os conhecimentos adquiridos no próprio Terreiro. 


\section{ERÊ DE AYRÁ}

Erê de Ayrá tem 18 anos de idade, autodeclarou-se negro e estuda no Colégio Estadual Duque de Caxias, cursando o terceiro ano do Ensino Médio. O que mais gosta da escola é a educação que é passada, diz que seus professores são muito competentes e têm postura de muito respeito com todos.

O entrevistado é Ogã confirmado para o Orixá Airá da Egbome Mariana. Participa do Candomblé desde que nasceu e tem cargo de Oloiêê24, aquele que faz tudo no Candomblé: cuida dos bichos; toca atabaques; cuida do salão; da comida e o que mais precisar. A mãe também é do Candomblé e o pai não tem religião. Ele descreveu, de forma muito amadurecida, a importância de tudo que aprende no Terreiro, sendo que, para ele, os 18 anos de convivência com a família Oxumarê fez com que aprendesse a ter uma postura muito séria e respeitosa com todos, afirmou ter sido "uma escola para a vida".

Erê de Ayrá disse que em nenhum momento da sua vida escolar se sentiu discriminado por causa da sua religião e, de acordo com ele, a sua postura de seriedade e respeito com os outros e todo seu conhecimento sobre os conceitos e práticas do Candomblé não permitiram que isso acontecesse. Ele sabe que na sua escola outros colegas sofreram esse tipo de racismo, mas ele, em particular, em nenhum momento passou por uma situação semelhante.

Como quase todos os entrevistados, ele relatou a alegria e felicidade que sente em ser do Candomblé, informou que o terreiro é a sua maior escola e que não pretende deixar 
a sua religião nunca. Pelo contrário, pretende ser um grande propagador desses fundamentos para que cada dia menos pessoas sofram o racismo religioso por serem do Candomblé.

\subsection{O QUE DIZEM AS CRIANÇAS CANDOMBLECISTAS}

Após a transcrição e análise das entrevistas individuais, refletiu-se sobre os principais resultados alcançados a partir das questões que foram abordadas em todas as entrevistas e, apesar de não se tratar de pesquisa quantitativa, elaborou-se um quadro síntese para melhor visualização desses resultados, disponíveis a seguir.

Os quadros 3 A e 3 B sintetizam os resultados das entrevistas qualitativas realizadas nos Terreiros llê Axé Odara e llê Axé Oxumarê; dessa forma, constata-se que, entre os pesquisados, quatro estão acima dos 15 anos, dois entre 11 e 15 anos e três com até 10 anos de idade. Sete deles frequentam o terreiro desde criança, sendo que seis desde que nasceram, e apenas três dos entrevistados conheceram - Candomblé após os 10 anos de idade.

Dos nove entrevistados, cinco declararam que se assumem, na escola, como religiosos de matriz africana, e quatro escondem a sua condição de candomblezeira. Somente o Erê de Aira, entre os cinco entrevistados que se declararam religiosos de matriz africana, afirma que nunca sofreu racismo religioso na escola, de acordo com ele, devido a sua postura de respeito com todos os colegas. Além de muita segurança ao falar sobre sua religião, porém, já presenciou outros colegas da escola serem discriminados. Os quatro 


\section{Quadro 3 A - Síntese das entrevistas qualitativas, TERREIRO ILÊ AXÉ ODARA.}

\begin{tabular}{|c|c|c|c|c|c|}
\hline $\begin{array}{l}\text { NOME } \\
\text { ADOTADO NA } \\
\text { PESQUISA }\end{array}$ & $\begin{array}{l}\text { IDADE } \\
\text { (ANOS) }\end{array}$ & $\begin{array}{l}\text { TEMPO NO } \\
\text { CANDOMBLÉ } \\
\text { (ANOS) }\end{array}$ & $\begin{array}{l}\text { ASSUME SUA } \\
\text { RELIGIÃO NA } \\
\text { ESCOLA }\end{array}$ & $\begin{array}{c}\text { DECLAROU QUE SOFREU RACISMO } \\
\text { RELIGIOSO }\end{array}$ & $\begin{array}{c}\text { RECONHECEU O TERREIRO COMO } \\
\text { ESPAÇO DE EDUCAÇÃO }\end{array}$ \\
\hline Erê de lansã & 17 & 06 & SIM & $\begin{array}{l}\text { "Já fui chamada de macumbeira } \\
\text { e fazedora de coisa ruim, mas não } \\
\text { liguei". } \\
\text { Declarou que foram feitas } \\
\text { brincadeiras pejorativas em relação } \\
\text { a sua religião. Levar estas ofensas } \\
\text { como forma de brincadeira é uma } \\
\text { das formas que o racismo tem de } \\
\text { esconder a realidade que passa o } \\
\text { povo negro e religiosos de matriz } \\
\text { africana. }\end{array}$ & $\begin{array}{l}\text { "Pai de Santo fala da África e dos } \\
\text { ensinamentos dos ancestrais, ensina } \\
\text { como se comportar na vida, pedindo } \\
\text { licença, respeitando os mais velhos } \\
\text { e aprendendo através da observação } \\
\text { e do cuidado que o Babalorixá tem a } \\
\text { ensinar". }\end{array}$ \\
\hline $\begin{array}{l}\text { Erê de } \\
\text { Yemanjá }\end{array}$ & 17 & 17 & SIM & $\begin{array}{l}\text { A maltratam e a ofendem, } \\
\text { principalmente quando está em } \\
\text { "obrigação", já que nesse período } \\
\text { ela não vai para a escola de farda, } \\
\text { e sim de roupa de terreiro, já } \\
\text { que a escola permite, porém, as } \\
\text { ofensas são recorrentes: “lá vem a } \\
\text { macumbeira, lá vem a feiticeira”. }\end{array}$ & $\begin{array}{l}\text { "No terreiro se aprende ensinando ou } \\
\text { observando o Pai e as mais velhas, o } \\
\text { terreiro é uma escola, pois, ajuda na } \\
\text { convivência fora do terreiro". Existem } \\
\text { duas pedagogias: a formal e a do } \\
\text { cotidiano no Terreiro. }\end{array}$ \\
\hline $\begin{array}{c}\text { Erê de } \\
\text { Obaluayê }\end{array}$ & 08 & 08 & NÃO & $\begin{array}{l}\text { "Se eu falar vão me chamar de } \\
\text { macumbeiro", "zombarem", "se eu } \\
\text { falar vão rir de minha cara e falar } \\
\text { muitos coisas ruins". }\end{array}$ & $\begin{array}{l}\text { No Terreiro ele aprende a "respeitar } \\
\text { os mais velhos, a respeitar o Orixá, a } \\
\text { tocar os atabaques, falar outra língua } \\
\text { (Bantu), e sempre observar o que os } \\
\text { mais velhos estão fazendo". }\end{array}$ \\
\hline $\begin{array}{l}\text { Erê de } \\
\text { Oxum } 1\end{array}$ & 18 & 04 & NÃO & $\begin{array}{l}\text { “[...] não queria ser zoada, eu } \\
\text { escondia minha condição, já } \\
\text { presenciei uma colega sofrer uma } \\
\text { grande discriminação que fez ela } \\
\text { se afastar da escola, então não me } \\
\text { apresentava de candomblé. Queria } \\
\text { que essa cidade me enxergasse } \\
\text { como uma pessoa normal, me sinto } \\
\text { abalada psicologicamente [...]”. }\end{array}$ & $\begin{array}{l}\text { "Vejo o terreiro como um lugar que } \\
\text { me ensina a ser uma pessoa melhor, } \\
\text { saio daqui sabendo que devo ajudar } \\
\text { as pessoas e respeitar ao próximo, não } \\
\text { discriminar nem por religião nem por } \\
\text { sua cor. } \\
\text { Relatou que, quando estava na escola, se } \\
\text { sentia outra pessoa, era triste e afastada } \\
\text { das colegas, não tinha alegria porque não } \\
\text { podia ser quem ela era, só se sentia "feliz, } \\
\text { satisfeita e completa quando estava no } \\
\text { ambiente do Terreiro". }\end{array}$ \\
\hline $\begin{array}{l}\text { Erê de } \\
\text { Xangô }\end{array}$ & 09 & 07 & NÃO & $\begin{array}{l}\text { Declarou que uma amiga já sofreu } \\
\text { muito por ter sido identificada como } \\
\text { adepta do candomblé. }\end{array}$ & $\begin{array}{l}\text { No candomblé ela gosta de dançar, } \\
\text { ver os Orixás e brincar com os Erês. } \\
\text { Além de aprender a dançar, também } \\
\text { é orientada a respeitar a natureza, } \\
\text { dessa forma, se sente muito feliz no } \\
\text { Terreiro. }\end{array}$ \\
\hline
\end{tabular}

Fonte: Dados do pesquisador. 


\section{Quadro 3 B - Síntese das entrevistas qualitativas. TERREIRO ILÊ AXÉ OXUMARÉ}

\begin{tabular}{|c|c|c|c|c|c|}
\hline $\begin{array}{c}\text { NOME } \\
\text { ADOTADO NA } \\
\text { PESQUISA }\end{array}$ & $\begin{array}{l}\text { IDADE } \\
\text { (ANOS) }\end{array}$ & $\begin{array}{l}\text { TEMPO NO } \\
\text { CANDOMBLÉ } \\
\text { (ANOS) }\end{array}$ & $\begin{array}{l}\text { ASSUME SUA } \\
\text { RELIGIÃONA } \\
\text { ESCOLA }\end{array}$ & $\begin{array}{c}\text { DECLAROU QUE SOFREU RACISMO } \\
\text { RELIGIOSO }\end{array}$ & $\begin{array}{c}\text { RECONHECEU O TERREIRO COMO } \\
\text { ESPAÇO DE EDUCAÇÃO }\end{array}$ \\
\hline $\begin{array}{l}\text { Erê de } \\
\text { Oxum } 2\end{array}$ & 13 & 13 & NÃO & $\begin{array}{l}\text { Quando fez as "obrigações de sete anos" } \\
\text { do candomblé e teve que ir para a escola } \\
\text { usando roupas brancas e elementos } \\
\text { religiosos que a identificavam como de } \\
\text { Terreiro, foi isolada pelos colegas que } \\
\text { olhavam para ela com "rosto de nojo e } \\
\text { desrespeito", tendo sido chamada de } \\
\text { macumbeira [...]. O sofrimento abalou } \\
\text { profundamente a mãe que não entendia } \\
\text { o que estava acontecendo porque ela } \\
\text { chorava tanto ao retornar da escola e } \\
\text { sentia-se muito deprimida, tendo vontade } \\
\text { até de abandoná-la. }\end{array}$ & $\begin{array}{l}\text { "[...] eu vinha para ao terreiro e ficava } \\
\text { olhando, observando e repetindo as coisas } \\
\text { feitas pelos mais velhos, sinto que todo } \\
\text { este aprendizado que tenho neste espaço é } \\
\text { bem diferente dos ensinamentos da escola, } \\
\text { [...] minha religião é tudo na vida, é onde } \\
\text { aprendo, ensino, estudo e me torno uma } \\
\text { pessoa melhor para mim e para os outros, } \\
\text { todos os dias". }\end{array}$ \\
\hline Erê de Nanã & 10 & 10 & SIM & $\begin{array}{l}\text { "Na sala tinha muitos alunos } \\
\text { evangélicos que falavam o tempo } \\
\text { todo mal da minha religião e eu ficava } \\
\text { com vergonha de falar, pois sabia que } \\
\text { sofreria racismo, mas este ano eu resolvi } \\
\text { assumir, [...]". Ele disse que depois do } \\
\text { seu anúncio pôde questionar as ofensas } \\
\text { e dizer para os colegas o que realmente } \\
\text { era o candomblé, tendo sido a sua } \\
\text { declaração importante, inclusive para } \\
\text { uma das suas professoras que também } \\
\text { é do candomblé e nunca teve coragem } \\
\text { de assumir e "com a minha atitude ela } \\
\text { sentiu-se fortalecida e depois deste dia } \\
\text { várias vezes passamos a falar sobre a } \\
\text { cultura e religião africana". }\end{array}$ & $\begin{array}{l}\text { Descreve com detalhes a importância da } \\
\text { educação que recebe no Terreiro para sua } \\
\text { formação na vida, com os ensinamentos da } \\
\text { religião que, segundo ele, são aprendidos } \\
\text { por meio da sua observação e também } \\
\text { das ações práticas como pegar uma folha } \\
\text { sagrada, cuidar dos atabaques, limpar } \\
\text { os Santos, varrer o Terreiro, limpar os } \\
\text { bichos. Ele relata que recebe diariamente } \\
\text { ensinamentos que vão formando sua } \\
\text { personalidade. Disse que o candomblé é } \\
\text { sua vida e que nasceu ali e "jamais sairá } \\
\text { do terreiro, é ali que aprendo, até mais do } \\
\text { que na escola". }\end{array}$ \\
\hline $\begin{array}{l}\text { Erê de } \\
\text { Oxumarê }\end{array}$ & 12 & 12 & SIM & $\begin{array}{l}\text { [...] todos sabiam que era do candomblé } \\
\text { e isto fez com que durante alguns anos } \\
\text { ela fosse muitas vezes ofendida por } \\
\text { todos, sempre que ela chegava para } \\
\text { participar das brincadeiras não era } \\
\text { bem aceita e os colegas mandavam ela } \\
\text { procurar Jesus porque ela tinha "parte" } \\
\text { com o diabo. }\end{array}$ & $\begin{array}{l}\text { No Terreiro ele aprende a "respeitar os } \\
\text { mais velhos, a respeitar o Orixá, a tocar } \\
\text { os atabaques, falar outra língua (Bantu). } \\
\text { e sempre observar o que os mais velhos } \\
\text { estão fazendo". }\end{array}$ \\
\hline Erê de Ayrá & 18 & 18 & SIM & $\begin{array}{l}\text { “[...] não queria ser zoada, eu escondia } \\
\text { minha condição, já presenciei uma } \\
\text { colega sofrer uma grande discriminação } \\
\text { que fez ela se afastar da escola, então } \\
\text { não me apresentava de candomblé. } \\
\text { Queria que essa cidade me enxergasse } \\
\text { como uma pessoa normal, me sinto } \\
\text { abalada psicologicamente [...]”. }\end{array}$ & $\begin{array}{l}\text { "Vejo o terreiro como um lugar que me ensina } \\
\text { a ser uma pessoa melhor, saio daqui sabendo } \\
\text { que devo ajudar as pessoas e respeitar ao } \\
\text { próximo, não discriminar nem por religião } \\
\text { nem por sua cor, } \\
\text { Relatou que quando estava na escola se } \\
\text { sentia outra pessoa, era triste e afastada das } \\
\text { colegas, não tinha alegria porque não podia } \\
\text { ser quem ela era, só se sentia "feliz, satisfeita } \\
\text { e completa quando estava no ambiente do } \\
\text { Terreiro". }\end{array}$ \\
\hline
\end{tabular}

Fonte: Dados do pesquisador. 
entrevistados que não assumiram na escola sua identidade religiosa afirmaram que não o fizeram por medo de serem maltratados pelos colegas, professores e gestores, já que tiveram oportunidade de presenciar outros colegas que são do Candomblé sofrerem racismo religioso e até mesmo abandonarem a escola.

Quando questionados pelo entrevistador sobre a importância do terreiro como espaço de educação, foram unânimes em falar da importância dos ensinamentos e da formação que recebem no terreiro, onde aprendem observando os mais velhos e acompanhando o dia a dia da rotina religiosa. Todos eles enfatizaram que a convivência no terreiro permite o aprendizado de valores éticos e morais, como respeito ao outro, principalmente aos mais velhos, a solidariedade, o respeito e o cuidado com a conservação da natureza, já que, de acordo com todos eles, o Candomblé não existe sem as "folhas".

As entrevistas deixaram bem claro para o pesquisador que as crianças e os jovens dos terreiros entrevistados têm plena convicção de que o terreiro tem sua própria pedagogia, que a forma de aprender nesse espaço religioso é bem diferente da escola. No terreiro, o ensinamento acontece por meio da prática, ao mesmo tempo que aprendemos com os mais velhos ensinamos aos mais novos em um aprendizado coletivo e dinâmico, sendo ao mesmo tempo aluno e professor. 



\section{6 \\ Palavra final: resistência}

Apesar de já terem se passado mais de cem anos da assinatura da lei que aboliu a escravidão, a sociedade brasileira continua sendo um espaço de manutenção das práticas racistas contra a população negra. A ideia de superioridade racial espelhada nos conceitos eurocêntricos, que justificavam a necessidade de utilização da mão de obra negra e gratuita para a acumulação de riquezas no processo de formação do mundo capitalista durante o Antigo Regime (Século XV ao XVIII), será reforçada com as teorias científicas do final do século XIX e início do século XX que, além de construir uma justificativa civilizatória para a dominação dos povos subalternizados pelos países europeus, insistiam em adotar uma política de embranquecimento da população negra, principalmente no Brasil, como forma de eliminação do maior número de negros da sociedade brasileira, mesmo após a abolição.

Essas práticas racistas se manifestam fortemente em relação às religiões de matriz africana, o que foi observado na pesquisa realizada, ao ouvir os relatos emocionantes de algumas das crianças e jovens, que se referiram inclusive 
a muitos casos de colegas que foram motivados a deixar de frequentar a escola por causa das perseguições diárias que sofriam, relacionadas ao racismo religioso. Percebe-se com mais clareza que conceituar estes atos apenas como intolerância é muito pouco abrangente. O que se observou, na prática, é que se trata de uma ação violenta de racismo religioso, que precisa ser rápida e sistematicamente combatida e denunciada. Passou-se então a adotar o conceito de Racismo Religioso.

A escrita deste livro possibilitou o aprofundamento na formação do autor, tanto no que se refere ao tema estudado especificamente, quanto à sua própria identidade que, em verdade, dialoga com a problemática da pesquisa propriamente dita. Quanto à questão da identidade pessoal, a elaboração do memorial do autor, que constitui o quarto capítulo deste livro, "O Eu no Outro: Reconhecendo-me Negro", foi fundamental, fortalecendo suas convicções e sua autoestima a partir da retrospectiva de sua atuação profissional e cidadã.

As entrevistas e observações realizadas, no âmbito da pesquisa de que trata essa obra, também revelaram esta situação de busca do embranquecimento ou até mesmo a indução por parte de professores e gestores para que as crianças fossem mais próximas à etnia branca como forma de evitar a discriminação. Esse distanciamento da sua condição de pessoa negra também se relacionava com a negação da sua condição de religioso de matriz africana, visto que até hoje os espaços sagrados do Candomblé, ou mesmo da umbanda, estão ocupados por maioria negra, e é sobre estas pessoas que as ações do racismo religioso recaem. 
Outra conclusão a partir das entrevistas realizadas com as crianças e jovens dos terreiros pesquisados, e também, das observações realizadas durante todo nosso trabalho nas escolas, foi a de que a expulsão dos europeus, colonizadores do Brasil, não significou a destruição da ideologia eurocêntrica construída por estes, durante toda sua permanência aqui em nosso país, principalmente no que se refere aos modelos e currículos pedagógicos aplicados.

Mesmo depois de mais de um século e meio da expulsão dos portugueses, as escolas observadas ainda continuam sendo responsáveis pela aplicação de um ensino monocultural, sem muita preocupação em tentar compreender as diversidades que existem nas salas de aula, sejam estas nas questões raciais, de gênero e quilombola. Sem um processo de formação continuada dos profissionais de educação, na perspectiva dos novos conceitos educacionais, a exemplo do multiculturalismo crítico de Peter McLaren, continuamos reproduzindo em nossos alunos um modelo de educação baseado em princípios eurocêntricos subalternizantes.

Acredita-se que, enquanto não houver uma reforma das práticas educacionais e pedagógicas, não acabará o racismo religioso sofrido pelas crianças e jovens de religião de matrizes africanas, aqui observadas, e mesmo de outras religiões.

É necessário introduzir novos conceitos de educação, compreendendo a real condição da sociedade, cada dia mais globalizada e interconectada, visando construir um modelo multicultural de educação que respeite as diferenças; entenda a vontade do indivíduo; considere as suas particularidades, ou seja, construir uma ideologia respeitosa, 
inclusiva e acolhedora, entendendo a importância de não continuar tratando seres diferentes de maneira igual. Ou seja, discutir os conteúdos educacionais a partir do olhar daqueles que foram subalternizados, permitindo que estes tenham o direito de falar de si próprios, expressar-se de diferentes formas.

No terreiro se aprende pelo exemplo, pela observação e pelo fazer cotidiano, uma prática educacional diária, uma via de mão e contramão, pois como defendia o educador Paulo Freire (2000, p. 54), “Ensinar não é transferir conhecimento, mas criar as possibilidades para sua própria produção ou a sua construção".

As crianças e os jovens de terreiros participantes da pesquisa expressaram a alegria e satisfação que sentem por fazerem parte dessa comunidade religiosa. Relataram que, no terreiro, sentem-se respeitados e valorizados nas funções que exercem para o bom funcionamento da casa, assim como na realização das obrigações religiosas.

Portanto, pode-se concluir que o espaço de educação formal atual precisa ser modificado, aproximando-se mais do modelo de educação não formal que existe nos terreiros, e de métodos como o adotado por Paulo Freire, citado anteriormente, em termos de metodologia de aprendizado. O Multiculturalismo crítico, adotado como referência nesta pesquisa é, sem dúvida, um método a ser considerado e adotado, com as adaptações a cada lugar e cada tempo.

Espera-se que este livro possa ser um instrumento de combate às práticas de racismo religioso, de avanço para métodos curriculares e práticas mais inclusivas nas 
escolas e também abra espaço para novas pesquisas e projetos acadêmicos, que contribuam com o fim desse modelo eurocêntrico de educação que permanece nas salas de aula, possibilitando a construção de uma sociedade mais justa e igualitária, onde ninguem possa mais estar submetido a uma dominação de um grupo superior que diz não ter preconceito porque tolera a religiosidade dos outros grupos, por ele considerados inferiores.

Os religiosos de matriz africana não querem ser apenas tolerados, exigem que sejam definitivamente respeitados na sua crença, nos seus ritos e na sua ancestralidade. 


\section{referências}

A CASA DE OXUMARÊ. A Casa de Oxumarê. Salvador, 2012. Disponível em: http://www.casadeoxumare.com.br/. Acesso em: 30 jan. 2018.

ALBUQUERQUE, Vlamira R. de; FRAGA FILHO, Valter. Uma história do negro no Brasil. Salvador: Centro de Estudos Afro-orientais. Brasília: Fundação Cultural Palmares, 2006.

AMORIM, Paulo Henrique. O Axé quebra protocolo para proteger tradições afrodescendentes. Revista Eletrônica Conversa Afiada, Salvador, 11 dez. 2012. Disponível em: https://www.conversaafiada. com.br/bqrasil/2012/12/11/o-axe-quebra-protocolo-para-protegertradicoes-afrodescendentes. Acesso em: 25 dez. 2018.

ANZALDÚA, Glória Evangelista. Falando em línguas: uma carta para as mulheres escritoras do terceiro mundo. Revista Estudos Feministas, Florianópolis, v. 8, n. 1, p. 2, 2000.

ARAÚJO, Glauco. Demolição de terreiro provoca polêmica em Salvador. Portal G1, Salvador, 18 mar. 2008. Disponível em: http://g1.globo.com/Noticias/Brasil/O,,MUL353993-5598,O0-DE MOLICAO+DE+TERREIRO+PROVOCA+POLEMICA+EM+SALVADOR. html\#: : text=O\%2Oterreiro\%200y\%C3\%A1\%200nip\%C3\%B3\%20 Neto,manifesta\%C3\%A7\%C3\%B5es\%2Ocontra\%20a\%2O intoler\%C3\%A2ncia\%2Oreligiosa. Acesso em: 25 abr. 2018.

ARAÚJO, Patrício Carneiro. Entre o terreiro e a escola: lei 10.639 e a intolerância religiosa sob o olhar antropológico. 2015. 255 f. Dissertação (Doutorado em Antropologia) - Pontifícia Universidade Católica de São Paulo, São Paulo, 2015. 
BAHIA. Lei $\mathbf{2 5 . 0 9 5}$ de 15 de janeiro de 1976. Desobrigou os terreiros de Candomblé a fazer o registro e tirar licença para a realização das festas. Disponível em: http://www.fpc.ba.gov.br/modules/noticias/article. php?storyid=1305. Acesso em: 7 set. 2020.

BAHIA. Lei 13.182 de 06 de junho de 2014. Institui o Estatuto da Igualdade Racial e de Combate à Intolerância Religiosa do Estado da Bahia. Disponível em: http://www.mpsp.mp.br/portal/page/portal/GT_Igualdade_Racial/ Outros/Lei\%2013.182\%2006.06.14\%2OBahia.pdf. Acesso em: 14 jun. 2017.

BAHIA, SECRETARIA DE PROMOÇÃO DA IGUALDADE RACIAL. Prêmio Manuel Faustino: catálogo de experiências. SEPROMI/BA, Salvador 2015.

BAKKE, Raquel Baptista Rua. Do Terreiro para a escola. Trabalho apresentado na 26a Reunião Brasileira de Antropologia de Porto Seguro, Bahia, 2012. Disponível em: www.abant.org.br. Acesso em: 30 out. 2018.

BASTIDE, Roger. O Candomblé da Bahia. São Paulo: Editora Schwarcz, 2001.

BENISTE, José. As águas de oxalá. Rio de Janeiro: Editora Bertrand, 2009.

BRAGA, Júlio. Na gamela do feitiço. Salvador: Editora EDUFBA, 1985.

BRASIL. [Constituição (1891)]. Constituição da República dos Estados Unidos do Brasil. Rio de Janeiro: Presidência da República, [1891]. Disponível em: http://www.planalto.gov.br/ccivil_03/constituicao/ constituicao91.htm. Acesso em: 14 jun. 2017.

BRASIL. Decreto n. 847, de 11 de outubro de 1890. Promulga o Codigo Penal. Rio de Janeiro. Disponível em http://www. planalto.gov.br/ ccivil_03/decreto/1851-1899/d847.htm. Acesso em: 10 set. 2020.

BRASIL. [Constituição (1988)]. Constituição da República Federativa do Brasil. Brasília, DF: Presidência da República, [2020]. Disponível em: http://www.planalto.gov.br/ccivil_03/constituicao/constituicao.htm. Acesso em: 24 set. 2018 . 
BRASIL. Estabelece as diretrizes e bases da educação nacional, para incluir no currículo oficial da Rede de Ensino a obrigatoriedade da temática "História e Cultura Afro-Brasileira". Disponível em: http://www. planalto.gov.br/ccivil_03/leis/2003/L10.639.htm. Acesso em: 15 jun. 2017.

BRASIL. Garante a reserva de $50 \%$ das matrículas por curso e turno nas 59 universidades federais e 38 institutos federais de educação, ciência e tecnologia a alunos oriundos integralmente do ensino médio público, em cursos regulares ou da educação de jovens e adultos. Brasília, DF: Presidência da República [2012]. Disponível em: http://portal.mec. gov.br/cotas/perguntas-frequentes. Acesso em: 9 set. 2020.

BRASIL. Estatuto da Igualdade Racial. Brasília, DF: Presidência da República [2010]. Disponível em: http://www.planalto.gov.br/ccivil_03/_ato20072010/2010/lei/l12288.htm. Acesso em: 15 jun. 2017.

BRASIL. Ministério da Educação. Plano nacional de implementação das diretrizes curriculares nacionais para educação das relações etnicorraciais e para o ensino de história e cultura afro-brasileira e africana. Brasília, DF: MEC, SECADI, 2013.

BROCOS, Modesto. A redenção de Cam. Disponível em: https://cutt.ly/ GgpVE1k. Acesso em: 20 out. 2018

CANDAU, Vera Maria Ferrão. Diferenças culturais, cotidiano escolar e prática pedagógica. Revista Currículo sem Fronteiras, Rio de Janeiro, v. 11, n. 2, p. 240-255, jul./dez. 2011.

CAPUTO, Stela Guedes. Educação nos terreiros: e como a escola se relaciona com as crianças de candomblé. Rio de Janeiro: Editora Pallas, 2012.

CAPUTO, Stela Guedes. Multiculturalismo: Diferenças Culturias e Práticas Pedagógicas. Petropolis: Editora Vozes, 2013.

CARNEIRO, Edison. Candomblés na Bahia. Rio de Janeiro: Civilização brasileira, 2002. 
CAVALLEIRO, Eliane (org.). Racismo e antirracismo na educação: repensando a nossa escola. São Paulo: Editora Selo Negro, 2001.

CAVALLEIRO, Eliane. Do silêncio do lar ao silêncio escolar: racismo, preconceito e discriminação na educação infantil. São Paulo: Editora Humanitas, 2000.

Coletivo de Entidades Negras - CEN. CEN Brasil Web, 2018. Disponível em: https://www.youtube.com/channel/UCM2OyRMAdZU9XU2Wc_ PqGJA/about?disable_polymer=1. Acesso em: 25 dez. 2018.

CIRNE, Ademar Oliveira Filho; SILVA, Luís Paulo. Mulheres de Axé: os Critérios de Escolha. In: REZENDE, Marcos (org.). Mulheres de Axé. Salvador: Editora Kawo Kabiyesile, 2013. p. 48-51.

COSTA, Emília Viotti da. Da senzala à colônia. São Paulo: Fundação Editora da UNESP, 1998.DIAS,

Luciana de Oliveira. Desigualdades étnico-raciais e políticas públicas no Brasil. Revista da Associação Brasileira de Negros, Vitória, v. 3, n. 3, p. 7-28, mar./jun. 2012.

DOMINGUES, Petrônio. Movimento Negro brasileiro: alguns apontamentos históricos. Tempo, Niterói, v. 12, n. 23, p. 100-122, 2007.

FREIRE, Gilberto. Casa grande e senzala. São Paulo: Global Editora, 2003

FREIRE. Paulo. Pedagogia da esperança. Rio de Janeiro: Editora Paz e Terra, 2003.

FREIRE, Gilberto. Pedagogia da autonomia. Rio de Janeiro: Editora Paz e Terra, 2000.

GOMES, Nilma Lino. Alguns termos e conceitos presentes no debate sobre relações raciais no Brasil: uma breve discussão. Portal Geledes. São Paulo, 13 mar. 2017. Disponível em: https://www.geledes.org.br/wpcontent/uploads/2017/03/Alguns-termos-e-conceitos-presentes-nodebate-sobre-Rela\%C3\%A7\%C3\%B5es-Raciais-no-Brasil-uma-brevediscuss \%C3\%A3o.pdf. Acesso em: 24 maio 2019. 
GOMES, Nilma Lino. Diversidade Étnico-racial por um projeto

emancipatório. Revista Retrato da Escola, Brasília, v. 2, n. 2-3, p. 95-108, 2008.

GROSFOGUEL, Ramón. A Estrutura do conhecimento nas universidades ocidentais: racismo/sexismo epistêmico e os quatros genocídios/ epistemicídios do longo século XVI. Revista Sociedade e Estado, Brasília, v. 3, n. 1, p. 40, jan./abr. 2016.

HIRONE, Fabiane; GOES, Antônio, Porque estimular a tolêrancia religiosa no ambiente escolar. Revista Aprendizado em Foco, São Paulo, n. 33, p. 3, 2017.

INSTITUTO BRASILEIRO DE GEOGRAFIA E ESTATÍSTICA. Censo Demográfico, 2010. Estimativa Populacional, 2018. Disponível em: https://censo2010.ibge.gov.br/resultados.html. Acesso em: 20 set. 2020.

LACERDA, João Batista de. Sobre os mestiços. In: CONGRESSO UNIVERSAL DAS RAÇAS, Londres: 1911.

LIMA, Claudiene dos Santos. O racismo religioso na Paraíba. 2012. Trabalho de Conclusão de Curso (Graduação em Pedagogia) Universidade Estadual da Paraíba, Guarabira, 2012.

MCLAREN, Peter. Multiculturalismo crítico. São Paulo: Editora Cortez, 1997.

MCLAREN, Peter. Multiculturalismo revolucionário. Rio de Janeiro: Editora Artmed, 2000.

MEMMI, Albert. Retrato do colonizador precedido do retrato do colonizado. Rio de Janeiro: Editora Paz e Terra, 1989.

MORANTE, Adélia Cristina Tortoreli; GASPARIN, João Luiz. Multiculturalismo e educação: um desafio histórico para escola. In: SEMINÁRIO NACIONAL DE ESTUDOS E PESQUISAS, [informar edição. Exemplo: 1., 2., etc.] 2006, Campinas. Anais [...]. Campinas: Unicamp, 2006. p. 3 
MOREIRA, Antônio Flávio; CANDAU, Vera Maria. Multiculturalismo:

diferenças culturais e práticas pedagógicas. Petrópolis, Rio de Janeiro: Editora Vozes, 2013.

MUNANGA, Kabengele. Educação e diversidade cultural. Cadernos PENESB, São Paulo n. 10, p. 42, 2010.

NASCIMENTO, Wanderson Flor. O fenômeno do racismo religioso: desafios para os povos tradicionais de matrizes africanas. Revista Eixo, Brasília, v. 6, n. 2, p. 53; 55, 2017.

PETAN, Antônio Carlos Lopes. Resumos de sociologia. Revista Café com Sociologia, São Paulo v. 2, p. 37, 2013.

REIS, João José; GOMES, Flávio dos Santos (org.). Liberdade por um fio: história dos quilombos no Brasil. São Paulo: Companhia das Letras, 1996.

REGO, Jussara. Intolerância religiosa. Revista Tempo e Presença digital, Salvador, v. 3, n. 12, 12 dez. 2008. Disponível em: http:// www.koinonia.org.br/tpdigital/detalhes.asp?cod_artigo=256\&cod_ boletim=14\&tipo=Artigo. Acesso em: 25 out. 2018.

REZENDE, Marcos (org.). Mulheres de Axé. Salvador: Editora Kawo Kabiyesile, 2013.

RODRIGÉ, Maria das Gras de Santana, Òri Àpuré Ó: o ritual da águas de Oxalá. São Paulo: Summus, 2001.

SCHWARTZ, Stuart B. Escravos, roceiros e rebeldes. Bauru: EDUSC, 2001.

SANTOS, Juana Elbein dos. Os nagô e a morte: Padê, Àsèsè e o culto Egum na Bahia. Rio de Janeiro: Editora Vozes, 2008.

SILVA, Maria José Albuquerque; BRANDIM, Maria Rejane Lima. Multiculturalismo e educação: em defesa da diversidade cultural. Fortaleza: Diversa, 2008.

SILVA, Uelber Barbosa. Racismo e alienação: uma aproximação à base ontológica de temática racial. São Paulo: Instituto Lukács, 2012. 
SILVERIO, Valter Roberto. Síntese da coleção História Geral da África: pré História ao século XVI. Brasília: UNESCO; MEC; UFSC, 2013.

LAHIRI. Victor. Yalorixá Mãe Gilda é homenageada com busto na Lagoa do Abaeté. Correio da Bahia, Salvador, ano 41. 21 jan. 2014.

SOARES, Afonso Maria Ligorio. Sincretismo afro-católico no Brasil: a lição de um povo no exílio. Revista de Estudos da Religião, São Paulo, n. 3, p. 45-75, 2002.

SOUZA, Kássia Mota. Entre a escola e a religião: desafios para crianças de Candomblé em Juazeiro do Norte. 2010. 145 f. Dissertação (Mestrado em Educação) - Universidade Federal do Ceará, Fortaleza. 2010.

SPIVAK, Gayatri Chakravoty. Pode o subalterno falar? Belo Horizonte: Editora UFMG, 2010.

THEODORO, Mário. As relações raciais, o racismo e as políticas públicas. In: ENCONTRO ANUAL DA ASSOCIAÇÃO NACIONAL DE PÓSGRADUAÇÃO E PESQUISA EM CIÊNCIAS SOCIAIS - ANPOCS, 37. 2013, Águas de Lindóia.

TRINDADE, Azoilda Loretto. O racismo no cotidiano escolar. Rio de Janeiro: Fundação Getúlio Vargas, 1994.

VERGER, Pierre. Fluxos e refluxos: do tráfico de escravos entre o golfo do Benin e a Bahia de Todos os Santos dos séculos XVII a XIX. Salvador: Editora Corrupio, 2002.

YARI, Carone; BENTO, Maria Aparecida Silva. (org.). Psicologia do racismo: estudos sobre branqueamento no Brasil. Petrópolis: Editora Vozes, 2012. 



\section{apêndice}

ROTEIRO DE ENTREVISTAS COM CRIANÇAS E JOVENS DE TERREIROS

1. Qual a sua cor? (Pergunta aberta feita a criança ou jovens)

2. Das cores abaixo, qual a sua? (Pergunta fechada feita às crianças ou jovens).

Branca ( ) amarela ( ) preta ( ) parda ( ) indígena( )

3. Onde você estuda?

4. Sua escola é particular ou pública?

5. Qual sua série?

6. O que você gosta da sua escola? Por quê?

7. Na sua escola tem aula de religião? Você participa? Por quê?

8. O que mais se fala nesta aula?

9. Qual a sua religião? 
10. Você é do Candomblé ou da umbanda?

11. Ha quanto tempo você participa do Candomblé?

12. Qual a sua função dentro do Candomblé?

13. Seus pais são do Candomblé?

14. Como você aprende as coisas no terreiro?

15. Os seus colegas de sala sabem que você participa do Candomblé?

Sim ( ) Não ( ).

Em caso de resposta negativa: Por quê?

Em caso de resposta positiva: Quem contou?

16. Os seus professores sabem que você é do Candomblé? Sim ( ) Não ( ) Em caso de resposta negativa: Por quê?

Em caso de resposta positiva: Quem contou?

17. A diretora ou diretor sabe que o Candomblé é a sua religião?

Sim ( ) Não ( ) Em caso de resposta positiva: Por quê?

Em caso de resposta negativa: Quem contou?

18. Algum funcionário ou funcionária da escola sabe da sua religião?

Sim ( ) Não ( ) Em caso de resposta positiva: Por quê?

Em caso de resposta negativa: Quem contou?

19. Você já levou alguém de sua escola para conhecer o terreiro? 
Sim ( ) Não ( ) Em caso de resposta negativa: Por quê?

Em caso de resposta positiva: Quem foi a pessoa? O que ela achou do terreiro?

20. Você gosta de ser do Candomblé?

21. Quando você está em obrigação, você vai para a escola com suas roupas brancas e suas contas de Orixá? $\operatorname{sim}($ ) Não( ).

Em caso de resposta negativa: Por quê?

Em caso de resposta positiva: O que dizem os seus colegas? E os seus professores?

22. Alguma vez você já se sentiu discriminada na escola por causa da sua cor e da sua religião?

Em caso de resposta positiva: Pode contar como foi? Qual sua atitude em relação ao fato?

23. Seus pais já foram chamados à escola para conversar com a diretora ou coordenadora para falar sobre sua religião?

24. Tem outros colegas da escola do Candomblé?

25. Vocês conversam sobre o que passam?

26. Nos eventos da escola você se sente excluída? Sim ( ) Não( ) Em caso negativo: Por quê? Em caso positivo: Você sabe por que isto acontece? 


\section{posfácio}

TRANSFLUÊNCIA, LIVROS CONTRACOLONIAIS

É preciso "superar o caráter autoritário do atual Estado Democrático de Direito", para que "toda e qualquer proposta de mudança seja exaustivamente debatida, respeitando-se as mais diversas formas de linguagem e de comunicação", escreve Antônio Bispo dos Santos (2015, p. 97), em livro intitulado Colonização, Quilombos: modos e significados.

O caminho para tal superação, nomeada pelo autor de "contracolonização", passa pela formulação de alguns conceitos teórico-metodológicos, como 'confluência', 'transfluência', 'tradutor entre mundos', 'reedição' de palavras, de narrativas e de epistemologias. Passa também pela escrita como campo de disputa, dispositivo a ser apropriado como "uma arma do inimigo para transformá-la em defesa" (SANTOS, 2018, s.p.).

Um entre esses modos de pensar-fazer, "transfluir", foi adotado por nós como nome da série de livros nascida de pesquisas de pós-graduação vinculadas à Universidade Federal do Sul da Bahia (UFSB). As três pesquisas que compõem a série saíram de cada uma das sedes da UFSB, divididas em três 
campi, constelados em rede e enraizados geopoliticamente nos municípios de Itabuna, Porto Seguro e Teixeira de Freitas.

Em agosto de 2020, firmando uma parceria interinstitucional com a Universidade Estadual de Santa Cruz (UESC), por meio de sua editora universitária, a Editus, o Programa de Pós-Graduação em Ensino e Relações Étnico Raciais (PPGER/ UFSB) cria oficialmente a série de livros "Transfluência: Ensino, Gênero e Relações Étnico-Raciais".

As três obras inaugurais dessa série foram selecionadas por meio de edital público. Puderam concorrer a esse edital todas/os que, na ocasião, estivessem vinculadas/os ao PPGER: discentes, docentes, grupos de pesquisa, comissões científicas de eventos ocorridos desde a abertura das atividades de formação do curso, em setembro de 2017. As três autorias selecionadas para os primeiros números da série são estudantes egressos da primeira turma de mestrandas e mestrandos do programa.

De modo geral, para estudantes de pós-graduação, a publicação de seus trabalhos, oriundos de projetos de pesquisas, pode significar reconhecimento público, amplo e estratégico de seus percursos formativos, escolhas e proposições teórico-metodológicas. Na tradição das Ciências Humanas, a publicação de livros é um dos caminhos para o tornar-se autor/a, reconhecida/o pelos pares. Mesmo assim, o trabaIho de conclusão em nível de mestrado nem sempre toma o caminho do livro, parando no repositório institucional. $\mathrm{Na}$ contramão disso, esta série traz a questão da transposição da dissertação para livro, como processo formativo, como alargamento do raio de impacto dos trabalhos realizados no PPGER/ UFSB. Além disso, põe em perspectiva o livro como retorno de 
pesquisas gestadas em escolas, quilombos, terreiros e aldeias, encorajando a expansão e o amadurecimento dos trabalhos de conclusão de curso no terreno da publicação como etapa legítima do desenvolvimento teórico-reflexivo.

No caso específico do PPGER, tais autorias são significativamente contra-hegemônicas, densamente territorializadas em comunidades de tradição oral, marcadamente dissidentes e insurgentes em seus contextos de produção e suas propostas epistemológicas. Participam, por essa via, do esforço de criação de diversas formas de linguagem para pesquisas resolutivas e mídias de comunicação que sejam capazes de abrir caminho à superação das colonialidades autoritárias de um Estado Democrático de Direito, que ainda não encontrou um conjunto de textos, uma convergência plural de diferentes sistemas de pensamento, capaz de assegurar os debates necessários ao viver em comum, sem a eliminação compulsória das diferenças.

Para Antônio Bispo dos Santos (2015, p. 89, grifos
nossos),

confluência é a lei que rege a relação de convivência entre os elementos da natureza e nos ensina que nem tudo que se ajunta se mistura, ou seja, nada é igual. [...] [E contrapondo-se a essa lei,] transfluência é a lei que rege as relações de transformação dos elementos da natureza e nos ensina que nem tudo que se mistura se ajunta.

Em um tensionamento dos opostos, para Santos (2015), ainda seguindo as letras de seu livro, nós aprendemos a confluir com os povos da terra, com os povos de tradição oral (quilombolas, de terreiros, povos indígenas, afroindígenas, 
etc.), de lógica cosmovisiva circular; e aprendemos a transfluir com os povos de tradição escrita, com lógica cosmovisiva linear e pensamento monista.

Com o abandono dos tensionamentos binários, em nossas mãos, no ponto de encontro de diferentes águas, no encruzilhar de diferentes tradições civilizatórias, detenhamos nosso olhar nas lições aprendidas no livro de Bispo dos Santos (2015, p. 89): "nem tudo que se ajunta se mistura, ou seja, nada é igual" e "nem tudo que se mistura se ajunta".

Façamos assim para, então, indagar: até onde é possível compor uma série de livros em que se guardem - sejam transmitidos - gestos múltiplos, diferenças agonísticas, autorias dissidentes, saberes insurgentes e não hegemônicos, epistemologias contracoloniais, quando nos defrontamos com as colonialidades e o racismo estrutural de nosso atual Estado Democrático de Direito?

\section{Das águas: corpos e corpus}

Trabalho com os conceitos de "confluência" e "transfluência". Confluência foi um conceito muito fácil de elaborar porque foi só observar o movimento das águas pelos rios, pela terra. Transfluência demorou um pouco mais porque tive que observar o movimento das águas pelo céu. Para entender como um rio que está no Brasil conflui com um rio que está na África eu demorei muito tempo. E percebi que ele faz isso pela chuva, pelas nuvens. Pelos rios do céu. Então, se é possível que as águas doces que estão no Brasil cheguem à África pelo céu, também pelo céu a sabedoria do nosso povo pode chegar até nós no Brasil (SANTOS, 2018, s.p.). 
Recomecemos de outro modo. Porque, sim, as águas têm memórias. Ficam nelas entranhadas tantos lugares por onde escorrem nas veias da terra, tantas gentes e saberes que com elas fluem. Para nós, são esses rios do céu, nas ensinanças de Antônio Bispo dos Santos (2018), que inspiram o projeto editorial da série de livros "Transfluência".

De como os rios de África chegam no Brasil. De como a distância territorial, o apartamento afrodiaspórico do território não apaga os elos, os saberes, os diferentes modos de ensinar e de aprender, a comunicação entre mundos. Feitiçaria que corre pelas águas trazendo recados, recuperando histórias subterrâneas dos lençóis freáticos, dos rios que correm e a-fluem a céu aberto, dos oceanos que fazem grandes conexões continentais. A feitiçaria como tradução, como quem extrapola o interlinguístico e habita o entre-lugar dos mundos, a articulação de modos dissidentes de existir, como "um intérprete a serviço da transmutação", como ensina Tiganá Santana (2018, p. 12).

Uma série de livros escritos por autoras e autores que também se arriscam como tradutoras e tradutores interculturais e pluriepistêmicos, como corpos cognoscentes, heteróclitos e transcriativos, escrevendo um corpus, conjunto de obras, heteróclito e transcriativo. Uma série de livros como coleção bibliográfica e materialidades de experiências de vida que são resultado das pesquisas e fortuna crítica para novas pesquisas. Pensamos aqui, mais uma vez, inspiradas por algumas noções metodológicas e teóricas de Antônio Bispo dos Santos (2018, s.p.) - "Minhas mais velhas e meus mais velhos me formaram pela oralidade, mas eles mesmos me colocaram na escola para aprender, pela linguagem escrita, a traduzir 
os contratos que fomos forçados a assumir"; pela noção de transcriação de Haroldo de Campos (2013); e, sobremaneira, pela noção de história, de Beatriz Nascimento (2018, p. 333) - "A memória são conteúdos de um continente, da sua vida, da sua história e do seu passado. Como se o corpo fosse o documento".

Em seguida, Célia Xakriabá (2020) nos diz que todo corpo é território e está em movimento, em permanente (re) territorialização. E, com isso, reivindica uma educação territorializada, ao contrário daquela desagregadora, característica historicamente encarnada pelas instituições formais de ensino. "Amansar o giz", então, é "ressignificar a escola", diz ela, no reconhecimento dos valores e dos elementos de cada corpo-território, como lugar potente de articulação entre saberes, mas sobretudo com o que o território nos alimenta, nos ensina e nos constitui (XAKRIABÁ, 2020, s.p.).

Passa um córrego, corre um rio submerso, em uma das cidades-sede do PPGER, Itabuna, cujo nome é Burundanga e sobre o qual uma escola pública foi construída. Um fragmento da memória desse corrégo-rio, degradado e tornado invisível a olho nu, torna-se legível para nós a partir de uma fala-escrita de Carlos Alberto Araújo dos Santos, Egbomin Alaboji, do llê Axé ljexá Orixá Olufon. Aqui vertida, em versão transcriada, uma narrativa brota reeditada: em uma cartografia geopolítica de mar de morros, os rios Burundanga e Jeribucassu caminham juntos, fazem parte da costa rochosa no litoral sul da Bahia. Córrego, rio, BURUNDANGA. Aqui, como nas Africanidades diaspóricas, as línguas, os corpos e as paisagens caminham juntos, perfazem encontros afroindígenas: Buru: enorme; Dan: serpente; Ga: alto. BURUNDANGA. A serpente 
que veio e nasceu do alto. Seixos de línguas: tupi, iorubá. Em relação à topologia cultural da nascente desse córrego, ou rio, dizemos: as águas descem do alto serpenteando. Dito de outro modo, "as águas descem sinuosas como uma enorme serpente". Nessa manhã inaugural, que perdura ainda, "em que o céu está em festa e mais colorido: a Serpente Sagrada do Povo Gege risca os Céus!".

Temos aprendido com nossos mais velhos, pela oralidade e pela escrita. Reeditando narrativas, aprendemos. Somos feitos de muitas comunidades, de mil povos e incontáveis nações. As mais de mil nações dos povos originários, entre as quais estão os Tupinambá, os Pataxó, os Pataxó Hã Hã Hãe, que habitam regiões ancestrais e contemporâneas no Sul da Bahia e nos ensinam seus modos de fazer-pensar; e as nações diaspóricas africanas são muitas, sabem ser uma e ser mil, a uma só vez:

\footnotetext{
A sobrevivência da cultura africana se fez no Brasil a partir de três grupos ou três nações: a Gege, que está quase acabando, a Ketu que domina hoje, que centraliza hoje uma ortodoxia, uma teologia que é Ketu-Nagô, porque há várias nações Nagôs e o Angola, que é talvez o sincretismo brasileiro dessas experiências africanas (NASCIMENTO, 2018, p. 333).
}

Sobrevivências, re-existências, corpos com memória de águas e das paisagens que habitamos. Atravessados por pensamentos, teorias, métodos, cartografias, biografias narrativas, trajetos de pesquisas, transfluentes, como bem sabem ser as águas das chuvas, dos rios, dos mares, dos mangues, da terra; e confluentes, como bem sabem ser as/os que perfazem diferentes ciclos de mundos no mundo. São com tais 
corpus e corpos que esperamos fazer compor e ampliar, ano a ano, a série aberta de livros "Transfluência: Ensino, Gênero, Relações Étnico-Raciais".

Um corpus, portanto, para a série "Transfluência", como corpo-território, corpo-documento, como política editorial, que deseja se alinhar às genealogias orais de linhagem de livros que se sabem atos estético-políticos, cognitivos e de ensino. Para essas linhagens, há escritas não alfabéticas. Escritas de águas. Escritas das matas. Escritas de milênios, como pinturas rupestres, cantos, ritmos poéticos e de pensamentos orais, inscrições, demarcações de passagens, não de posse, mas de pertencimento, de partilha de vida, de bem comum.

\section{Tipografias líquidas, livros contracoloniais}

Tendo tudo isso em vista, como chegar no livro? O livro como materialização das brechas e flechas lançadas pelo nome que abre caminho dessa série? Que visualidades podem o constituir? Como curá-lo em seus caminhos editoriais e projeto gráfico?

O livro, como território historicamente aliado dos abusos e estigmas do Estado de Direito, assume toda a estirpe colonial como objeto de catequização e domínio. Opõe-se à oralidade. Afirma a escrita logocêntrica, alfabética.

Como pensar, porém, o livro de outro lugar? Como território potente de transformação, como trânsito entre mundos, como tramas interétnicas, como processos de subjetivação em trânsito, instáveis, dissidências, afirmação em devir. 
Como pensar agora o livro aberto, o livro mundo? 0 livro para fora, nas comunidades escolares, nas comunidades de terreiro, nas comunidades quilombolas, no enfrentamento das questões de gênero e dissidências sexuais? O livro cuja página é a floresta, cujas linhas são lidas na caída dos búzios, cujas grafias são a pele e suas inscrições sábias do tempo no corpo, livros-peles, livros-lugares.

Reconhecer o livro fora dos domínios da colonialidade, ver o livro aberto, implicado no território, a transfluir águas. Nelas: entes, encantados, voduns, orixás, inkises, ritos, saberes, narrativas, orikis, rezas, geomitologias, os diferentes corpos que as habitam, muitas dimensões do humano e de diversas cosmopercepções.

Vejamos o livro de água gráfica, da nascente à foz, do mar aberto à areia da praia, da lama profunda à superfície do mangue, tantas escritas e inscrições: quando a água passa, perfaz caminhos, ranhuras, topografias. Tantas memórias fincadas no chão por onde ela passou. No correr da viagem de uma vida que faz um rio: muitas águas se encontram. $\bigcirc$ encontro aqui é signo de movimento e mudança permanentes. O rio transcorre pelo território como uma cobra mudando de pele, na transmutação ligeira do espaço-tempo. É imperativo, sempre, continuar, como esta série de livros o fará.

O encontro é também faísca que transcorre quente, sinergia potente de criação, fricção. Quantos maus encontros promovidos pela colonização afro-pindorâmica, responsáveis por desterritorializações e reterritorializações monumentais e genocidas, transcorridas das águas de Áfricas embarcadas e aportadas nas Américas. Quantos encontros potentes de força encantatória também não se deram no bojo dessa 
invasão, tantas vezes reinstaurada no curso do tempo, entronizada no Brasil como projeto de normatização, sendo o encantamento "ato de desobediência, transgressão, invenção e reconexão: afirmação da vida" (SIMAS; RUFINO, 2020, s.p.).

As águas guardam, portanto, a memória desses tantos encontros de conexões afro-pindorâmicas, em diversas dimensões. Thiago de Melo (1984, p. 157-158) diz que as águas nunca se desgastam: "permanecem nas águas os elos das correntes invisíveis". Pois quantas marés há na memória da chuva? E na "maré dos olhos" como a "memória das corredeiras" que escapa do olhar perdido do velho Agodô no conto de Cidinha da Silva (2018)? "Devo contar o vivido, velho Agodô? Conte o que fizeste dele, minha filha. Isso basta, meu velho? Se basta não sei. Aviva" (SILVA, 2018, p. 27-28)? O corpo da terra, o corpo das gentes, corpo líquido, corpo vivo.

Se ainda é possível transfluir essas conexões, como nos convoca Antônio Bispo (2015, 2018), como os rios do céu que choram na chuva e nos trazem de volta memórias invisíveis, confluências continentais, fluxos e refluxos da transmutação da natureza, o livro aqui se coloca também como território de encontros. De modo que foi a água a chave-mestra do processo criativo do projeto gráfico desta série de livros, talhada em um conjunto de carimbos que, em relação, organizam e re-organizam múltiplos movimentos visuais. As águas e as cores. Cores terrosas, cores vibrantes. Tipografias líquidas. Nos carimbos, confluência de cores, de lógicas e de tempos históricos: a modernidade e a tradição sobrescritos no tempo presente. Carimbos gráficos, sulco artesanal na madeira, transposição ao digital, com combinações múltiplas, que denunciam sua técnica na textura, imperfeita e precisa, 
de fluxos vincados em sua matéria-prima. Gestos, traços de quem imprime como quem assenta na página percursos possíveis do macroterritório do Sul da Bahia. Essa é a nossa direção editorial.

\section{Agradecimentos}

Um livro, uma série de livros, não se concebe e nem se faz com poucas pessoas envolvidas. Há muito a agradecer. Mesmo correndo o risco de deixar de fora algum nome, e pedindo antecipadamente desculpas se isso ocorrer, agradecemos aos coordenadores locais do PPGER, Eliana Póvoas Pereira Estrela Brito e Gilson Brandão de Oliveira Junior. Ao coletivo de professores e discentes, e especificamente aqueles que trabalharam na Comissão de Seleção das obras: Hamilton Richard A. F. Santos, Francisco A. Nascimento Junior, Yuri Miguel Macedo (do campus Sosígenes Costa, PPGER Porto Seguro); Rebeca Valadão Bussinger, Francisco Antônio Nunes Neto, Paulo César Pereira de Jesus (do campus Paulo Freire, PPGER Teixeira de Freitas); Apoena Dandara Silva Santos (do campus Jorge Amado, PPGER Itabuna). Agradecemos a Rita Virgínia Argollo, Sabrina Nascimento, Conselho Editorial e toda equipe da Editus, parceria indispensável neste projeto. À equipe de revisores, José Pedro de Carvalho Neto e Tess Chamusca Pirajá. À equipe de artistas gráficos, Lia Cunha e Tiago Ribeiro. Às instituições Universidade Federal do Sul da Bahia e Universidade Estadual de Santa Cruz, com suas equipes de servidores públicos que viabilizaram cada passo do processo. Agradecemos aos autores que inauguram esta série de livros: Raíssa Félix, Kauan Almeida e Ademar Cirne, pelas trocas e aprendizados mútuos nesta tarefa de fazer chegar ao 
mundo dos livros seus percursos de pesquisa. Agradecemos, por fim e por início, a Kabengele Munanga: nosso mais velho, companhia que nos honra, nos fortalece, nos alegra, ao nos acolher e nos ensinar tanto e ao modo firme dos aquilombamentos ancestrais.

Cynthia Cy Barra e Laura Castro Coordenação Editorial do Projeto Transfluência Itabuna; Salvador, Bahia, outubro de 2020. 


\section{REFERÊNCIAS}

CAMPOS, Haroldo de. Tradição, transcriação, transculturação: o ponto de vista do excêntrico. In: TÁPIA, Marcelo; NÓBREGA, Thelma Médici (org.). Haroldo de Campos - Transcriação. São Paulo: Perspectiva, 2013. p. 197-205.

MELO, Thiago. Vento geral. Rio de janeiro: Civilização Brasileira, 1984.

NASCIMENTO, Maria Beatriz. Beatriz Nascimento: intelectual e quilombola. Possibilidade nos dias da destruição. São Paulo: Editora Filhos da África, 2018.

SANTANA, Tiganá. Breves considerações sobre um traduzir negro ou tradução como feitiçaria. Landa, Florianópolis, v. 7, p. 5-16, 2018. Disponível em: https://repositorio.ufsc.br/bitstream/id/ebf57f174593-4dcO-abe4-1d3212e4bf95/1.\%2OTIGANA\%2O-\%2OLISTO. pdf. Acesso em: 2 out. 2020.

SANTOS, Antônio Bispo. Colonização, Quilombo: modos e significados. Brasília: INCTI; UnB; INCT; CNPq; MCTI, 2015.

SANTOS, Antonio Bispo. Somos da terra. Piseagrama, Belo Horizonte, n. 12, 2018. Disponível em: https://piseagrama.org/somos-daterra/. Acesso em: 2 out. 2020.

SILVA, Cidinha da. O velho e a moça. In: SILVA, Cidinha da. Um Exu em Nova York. Rio de Janeiro: Pallas Editora, 2018. p. 27-28.

SIMAS, Luiz Antônio; RUFINO, Luiz. Encantamento (sobre política de vida). Rio de Janeiro: Mórula Editorial, 2020.

XAKRIABÁ, Célia. Amansar o giz. Piseagrama, Belo Horizonte, n. 14, 2020. Disponível em: https://piseagrama.org/amansar-o-giz/. Acesso em: 2 out. 2020. 


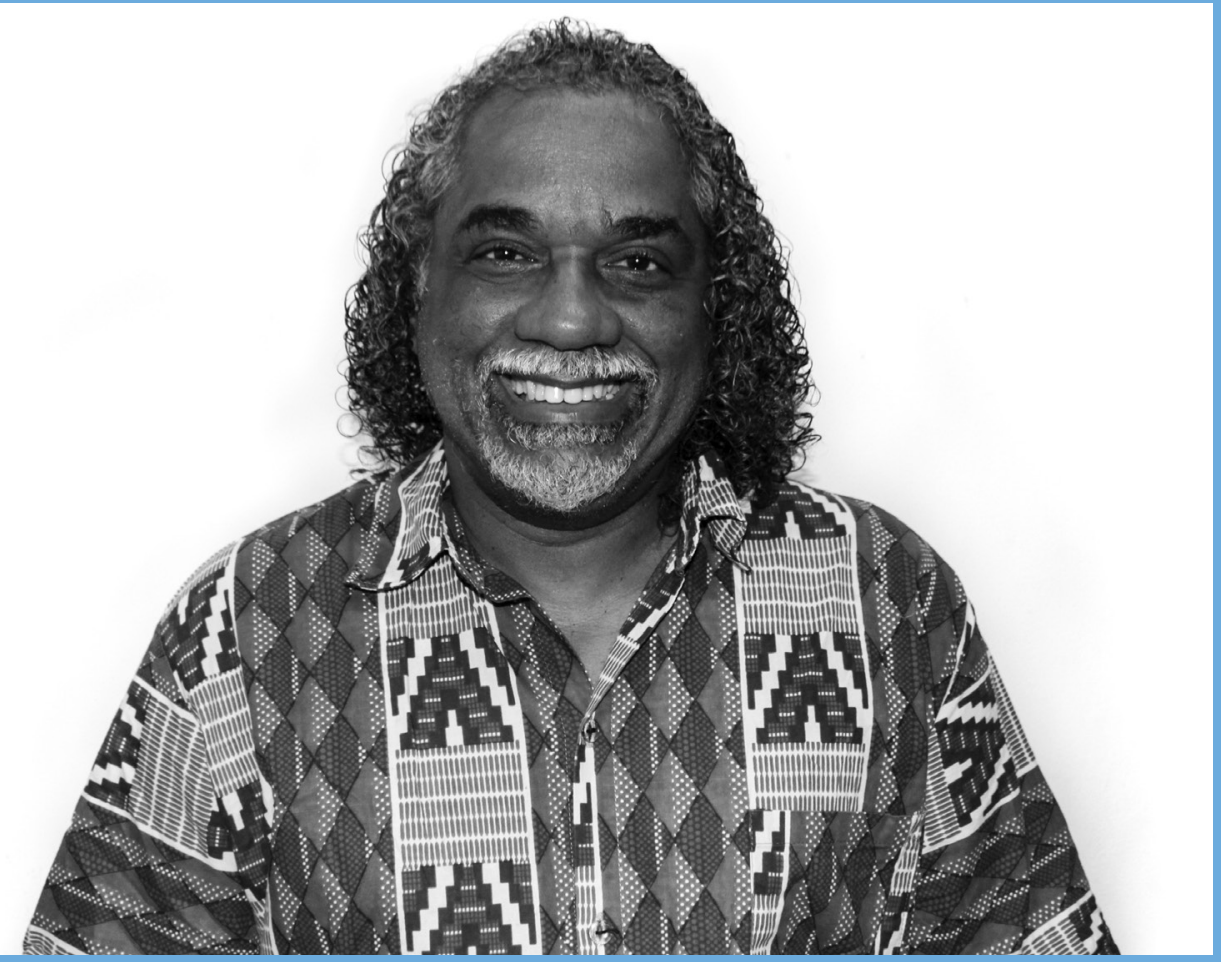




\section{sobre o autor}

Ademar Oliveira Cirne Filho, nascido em 1963, é natural de Salvador - Ba. Graduado em História pela Universidade Federal da Bahia (UFBA), pós-graduado em História do Brasil pela Pontifícia Universidade Católica de Minas Gerais (PUC Minas), especializado em Educação Étnico-Racial pela Universidade Estadual de Campinas (UNICAMP) e mestre em Ensino das Relações Étnico-Raciais pela Universidade Federal do Sul da Bahia (PPGER/UFSB). É professor de História, com ênfase em História do Brasil e da Bahia, há mais de 30 anos, atuando do ensino básico ao universitário. Religioso de Matriz Africana, é Ogã do Terreio llê Axé Oxumarê, bem como ativista social e militante do movimento negro há mais de 15 anos, ocupando várias coordenações no Coletivo de Entidades Negras (CEN). No momento, reside em Vitória da Conquista, onde se dedica à pesquisa nas áreas de educação antirracista e racismo religioso. 
Colofão

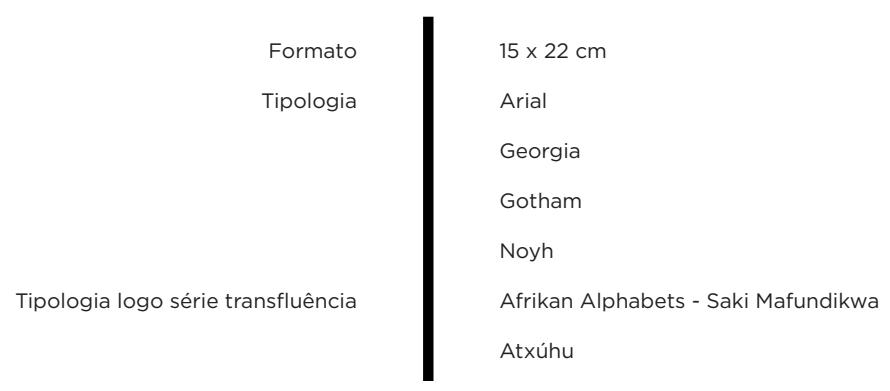

